Notre Dame Law School

NDLScholarship

Journal Articles

Publications

2008

\title{
The Supreme Court and the Politics of Death
}

Stephen F. Smith

Notre Dame Law School, ssmith31@nd.edu

Follow this and additional works at: https://scholarship.law.nd.edu/law_faculty_scholarship

Part of the Constitutional Law Commons, Criminal Law Commons, and the Law and Politics Commons

\section{Recommended Citation}

Stephen F. Smith, The Supreme Court and the Politics of Death, 94 Va. L. Rev. 283 (2008).

Available at: https://scholarship.law.nd.edu/law_faculty_scholarship/360

This Article is brought to you for free and open access by the Publications at NDLScholarship. It has been accepted for inclusion in Journal Articles by an authorized administrator of NDLScholarship. For more information, please contact lawdr@nd.edu. 


\section{VIRGINIA LAW REVIEW}

\section{ARTICLES}

\section{THE SUPREME COURT AND THE POLITICS OF DEATH}

\section{Stephen F. Smith*}

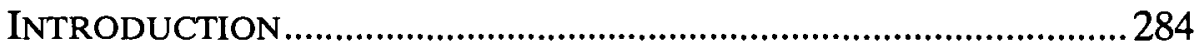

I. The Politicization of CAPITAL PUnishmenT......................... 286

A. Visibility of Capital Punishment .........................................2287

B. Popularity of Capital Punishment ........................................2291

II. DEATH's POLITICS..................................................................... 294

A. Legislative Incentives..............................................................295

1. Substantive Criminal Law .............................................2295

2. Remedies and Funding ................................................... 300

a. Limiting Judicial Remedies ....................................... 300

b. The Funding "Squeeze"............................................. 302

B. Incentives of Prosecutors (and Chief Executives)................. 307

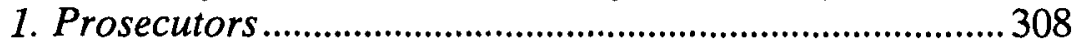

a. Resource Concentration ..............................................309

b. Avoiding Defeats ..................................................... 311

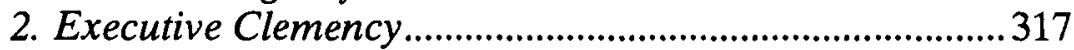

C. Judicial Incentives ................................................................ 328

D. Summary: The "Politicized" Death Penalty ......................... 334

III. TOWARD A NEW "POLITICAL" APPROACH TO DEATH

PENALTY REFORM ............................................................... 336

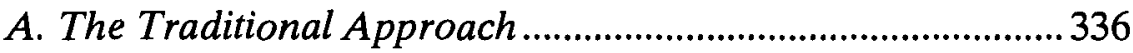

* Professor of Law and John V. Ray Research Professor, University of Virginia. For insightful comments and suggestions, I am indebted to Stephanos Bibas, Kim FordeMazrui, David Jacobs, John Jeffries, Mike Klarman, Caleb Nelson, Jim Ryan, Carol Steiker, and faculty workshop participants at the Georgetown, Notre Dame and University of California-Davis law schools. Any errors herein are mine, not theirs. Special thanks to Elizabeth Coe for excellent research assistance. 
B. The Emerging "Political" Approach .......................................340

1. Expanded Substantive Regulation .....................................341

2. Counteracting the Funding "Squeeze" ..............................346

a. The Traditional Ineffectiveness Standard.....................347

b. The New, "Political" Ineffectiveness Standard for Capital Cases ......................................................... 353

i. Strategy versus "Strategery" ..................................357

ii. Duty and Scope of Investigation ........................... 359

c. The Politics (and Promise) of the New

Ineffectiveness Standard ..............................................369

i. "Death Is Different" ..............................................370

ii. Avoiding Wrongful Executions ..............................373

iii. The Politics of Death ...........................................375

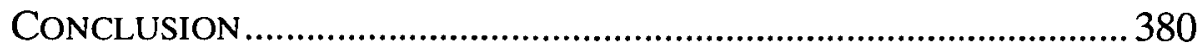

\section{INTRODUCTION}

FROM a comparative perspective at least, the continued vitality Fof the death penalty in the United States is perplexing. Throughout the rest of the Western world, capital punishment has been abolished as an ordinary criminal sanction. ${ }^{1}$ Furthermore, although there were virtually no abolitionist countries five decades ago, today most nations no longer enforce the death penalty as a sanction for ordinary crime. ${ }^{2}$ Prominent among the countries that do employ the death penalty are rogue, repressive, or fundamentalist regimes-not exactly the kind of company that Americans ordinarily wish to keep. ${ }^{3}$

In this country, politics-specifically, the "politics of death"have made capital punishment a persistent feature of the criminal landscape. This is not to say that capital punishment is inevitable in America. Indeed, by the 1960s, before the Supreme Court started regulating the death penalty in Furman v. Georgia, ${ }^{4}$ executions

\footnotetext{
${ }^{1}$ See generally Richard C. Dieter, Death Penalty Info. Ctr., International Perspectives on the Death Penalty: A Costly Isolation for the U.S. 5 (1999), available at http://www.deathpenaltyinfo.org/article.php?scid=45\&did $=536$.

${ }^{2}$ See id. at 23 (noting that the number of countries in which capital punishment has been abolished or is no longer used is "more than the total of countries which retain an active death penalty").

${ }^{3}$ See id. at 25 (listing countries that enforce the death penalty).

${ }^{4} 408$ U.S. 238 (1972) (per curiam).
} 
were on the decline. ${ }^{5}$ The federal government had not executed anyone since 1963 and would not do so again until $2001{ }^{6}$ States continued to hand down death sentences, but those sentences generated surprisingly few executions in the period leading up to Furman. From 1964 to 1966, there were only twenty-three executions nationwide, a three-year figure that pales in comparison to the ninety-eight executions in 1999 alone. ${ }^{7}$ The number of executions might well have continued to decline but for the Court's effort, in the early 1970s, to impose constitutional limits on capital punishment.

This Article explores the evolving role of the Supreme Court in the politics of death. Part I sets the stage by briefly sketching the politicization of capital punishment. By subjecting capital punishment to constitutional regulation, the Court set into motion political forces that have seriously undermined its vision of a death penalty that is fairly administered and imposed only on the worst offenders. Constitutional regulation of the death penalty, on this account, resulted in the politicization and entrenchment of capital punishment and, ultimately, substantially more executions that are no fairer than those from prior decades when capital punishment was unregulated.

Part II probes some of the key ingredients of death's politics. With the death penalty established as a highly salient political issue, politicians have strong institutional incentives to make death sentences easier to achieve. Legislatures expand the scope of the death penalty and restrict access to the courts for prisoners on death row. Most importantly, legislatures tie the hands of indigent defenders by denying them the funding and resources that they need, and that prosecutors receive, to be effective in resourceintensive capital trials. Prosecutors have incentives to use the death penalty as leverage to get defendants to plead guilty and, in cases where death will not be traded for guilty pleas, to win and carry out

\footnotetext{
${ }^{5}$ See id. at 291-93 (Brennan, J., concurring).

${ }^{6}$ See Rick Bragg, McVeigh Dies for Oklahoma City Blast, N.Y. Times, June 12, 2001, at A1.

${ }^{7}$ Compare Furman, 408 U.S. at 293 (Brennan, J., concurring) (recounting 1964-66 data), with Death Penalty Info. Ctr., The Death Penalty in 1999: Year End Report (1999), http://www.deathpenaltyinfo.org/article.php?scid=45\&did=266 (recounting 1999 data).
} 
death sentences. As resource-constrained capital defenders get steamrolled by prosecutors determined to win even at great cost, juries are given inadequate reasons for showing leniency (even when compelling reasons exist) and thus often respond with verdicts of death. Try as they might, state judges are, in the final analysis, unable to counteract the push toward death, and state governors will usually have strong incentives, except in clear cases of actual innocence or major failures of the judicial process, to punt the life/death decision to the courts.

Part III shows that the Supreme Court has recently begun to chart a different-and more promising-approach to death penalty reform. Historically, the Court's constitutional mandates have been oblivious to the politics of death and thus largely ineffective in their goal of promoting a fairer and more reliable death penalty. In two key areas, however, the Court has recently reinterpreted prior constitutional doctrines in ways that operate to counteract death's politics. These rules determine the type of offenses for which death is a "cruel and unusual" sanction (the Eighth Amendment's capital proportionality standard) and the quality of representation defendants must receive in capital cases (the Sixth Amendment's guarantee of effective assistance of counsel). The Court has transformed these rules from doctrines that previously had little effect on the administration of the death penalty into potent weapons for counteracting the politics of death and promoting the fairness and rationality of the capital sentencing process. The Article concludes with some thoughts concerning the implications of the new approach to regulating the death penalty for the future of capital punishment in America.

\section{The Politicization of Capital Punishment}

It would be natural to explain the persistence of capital punishment in America in terms of public opinion. Most citizens support the death penalty, ${ }^{8}$ and so the elected officials who are responsible for capital punishment-mainly legislators, prosecutors, judges, and governors in the state system-supply the death sentences the

\footnotetext{
${ }^{8}$ See Robert M. Bohm, American Death Penalty Opinion: Past, Present, and Future, in America's Experiment with Capital Punishment 27, 27 (James R. Acker et al. eds., 2 d ed. 2003).
} 
public desires. This account, however, is too simplistic given the momentous events of the last three decades.

Although public opinion has unquestionably played a role in the ongoing saga of the death penalty, that role is not what it appears to be at first blush. Since the 1970 s, public opinion concerning capital punishment has not driven politics; the chain of causation, oddly enough, has run in the opposite direction. In the early 1970 s, a time when the death penalty had surprisingly weak support nationally, ${ }^{9}$ the political system resoundingly embraced capital punishment. Judicial efforts to curtail sharply (if not eliminate) capital punishment had consequences that made the death penalty a highly salient political issue. The politicization of the death penalty, in turn, drove up public support for the death penalty and unleashed the "politics of death"-namely, the perverse incentives for political actors and judges in "death" states to perform their institutional functions in ways that result in more frequent, and less fair, application of the ultimate sanction.

This Part explains the rise and consequences of the politicization of the death penalty. The claim is that the politicization of the death penalty in the 1970 s was a watershed event because it set in motion the politics of death. The politics of death, a topic explored in detail in Part II, flow from the visibility and popularity of capital punishment-which are themselves products of the politicization of the death penalty.

\section{A. Visibility of Capital Punishment}

Prior to Furman v. Georgia, the death penalty was widely authorized, but actual executions were increasingly rare..$^{10}$ In this climate, voters would not expect to see lots of executions, even in murder cases. This gave elected state prosecutors considerable

\footnotetext{
${ }^{9}$ See infra notes $29-30$ and accompanying text.

${ }^{10}$ As Justice William Brennan explained in Furman:
}

There has been a steady decline in the infliction of [capital] punishment in every decade since the 1930's, the earliest period for which accurate statistics are available. In the 1930's, executions averaged 167 per year; in the 1940's, the average was 128; in the 1950's, it was 72; and in the years 1960-1962, it was 48. There have been a total of 46 executions since then, 36 of them in 1963-1964.

408 U.S. at 291 (Brennan, J., concurring). For a more extensive discussion, see Callins v. Collins, 510 U.S. 1141 (1994); Franklin E. Zimring \& Gordon Hawkins, Capital Punishment and the American Agenda 26-47 (1986). 
leeway not to press for death sentences, or to allow convicted prisoners to remain on death row indefinitely." State governors also liberally used their clemency power to grant mercy to persons sentenced to deatn. ${ }^{12}$ Thus, as the National Crime Commission itself noted in 1967, "all available data indicate[d] that judges, juries, and governors [we]re becoming increasingly reluctant to impose, or authorize, the carrying out of a death sentence."13

Furman, however, changed all that. With one blow, it struck down virtually every death penalty law nationwide. ${ }^{14}$ The Justices who supported the outcome declared that the ultimate sanction was too arbitrary in its application to pass constitutional muster. ${ }^{15}$ Over time, the Supreme Court decided a number of cases that fleshed out the meaning of Furman. States were required to develop meaningful criteria to "narrow" the discretion of jurors in selecting from among the universe of death-eligible defendants the few who most deserve death. ${ }^{16}$ In addition, a valid capital sentenc-

"At the time of Furman, more than six hundred inmates were on death row. Furman, 408 U.S. at 417. Some of the backlog of executions was attributable to the NAACP Legal Defense Fund's strategy of stalling executions by challenging the constitutionality of the death penalty. See Zimring \& Hawkins, supra note 10, at 33-34. Nevertheless, "the 'pileup on death row' had begun some time before the Legal Defense Fund launched its ['moratorium'] campaign in the mid-1960s." ld. at 34.

${ }^{12}$ See infra notes $129-130$ and accompanying text.

${ }^{13}$ President's Comm'n on Law Enforcement and the Admin. of Justice, The Challenge of Crime in a Free Society 143 (1967).

${ }^{14}$ See Furman, 408 U.S. at 411 (Blackmun, J., dissenting) ("Not only are the capital punishment laws of 39 States and the District of Columbia struck down, but also all those provisions of the federal statutory structure that permit the death penalty apparently are voided.").

${ }^{15}$ See id. at 255-57 (Douglas, J., concurring); id. at 295 (Brennan, J., concurring); id. at 309-10 (Stewart, J., concurring); id. at 313 (White, J., concurring); id. at 364 (Marshall, J., concurring). There was no majority opinion in Furman except for a short per curiam opinion announcing the result. Id. at 239-40. Each of the nine Justices wrote individual opinions explaining their votes in the case.

${ }^{16}$ See, e.g., Lowenfield v. Phelps, 484 U.S. 231, 244 (1988) ("[A] capital sentencing scheme must 'genuinely narrow the class of persons eligible for the dcath penalty and must reasonably justify the imposition of a more severe sentence on the defendant compared to others found guilty of murder." ' (quoting Zant v. Stephens, 462 U.S. 862, 877 (1983)). As a leading account explains:

[T]his doctrine--which we call "narrowing"-seeks to force communities, speaking through state legislatures, to designate in advance those offenders most deserving of death. By forcing states to articulate their theories of the "worst" offenders, the narrowing doctrine purportedly guards against "overinclusion"-that is, the application of the death penalty in circumstances in which, 
ing scheme was required to include procedural safeguards ensuring that, in each case, there would be a reliable, individualized determination of whether or not death should be imposed." Absent compliance with these principles, executions would no longer be constitutionally permissible.

After Furman, the death penalty moved front and center in the political arena. State legislatures, which were previously content to sit on the sidelines as the number of death sentences imposed and actually carried out in their states dwindled, sprang into action. Faced with what they took to be an unjustified assault on their prerogatives, legislatures quickly revised their death penalty statutes to satisfy the new constitutional mandates. ${ }^{18}$ Indeed, one previously abolitionist state (Oregon) changed sides and moved into the death penalty camp. ${ }^{19}$ The unprecedented speed and vehemence of the

notwithstanding the sentencer's decision, the sentence is not deserved according to wider community standards.

Carol S. Steiker \& Jordan M. Steiker, Sober Second Thoughts: Reflections on Two Decades of Constitutional Regulation of Capital Punishment, 109 Harv. L. Rev. 355, 372 (1995).

${ }^{17}$ Both the individualization and reliability requirements have roots in Woodson $v$. North Carolina, 428 U.S. 280 (1976), where the Court ruled that mandatory death penalty statutes are unconstitutional. Id. at 305 (plurality opinion). Such statutes are objectionable, the plurality ruled, because they treat all persons convicted of capital murder as equally deserving of death instead of "allow[ing] the particularized consideration of relevant aspects of the character and record of each convicted defendant before the imposition upon him of a sentence of death." Id. at 303. If, as Woodson held, death may not be imposed except on the basis of individualized desert, then the sentencing process had to be structured to achieve "reliability in the determination that death is the appropriate punishment in a specific case." Id. at 305 . For an excellent distillation and collection of the various principles inherent (or later said to be inherent) in Furman, see Steiker \& Steiker, supra note 16, at 361-71.

${ }^{18}$ The reaction was astonishingly swift: "[B]y 1976, 35 states and the federal government had redrafted their capital punishment statutes in order to maintain their authority to execute post-Furman." Steiker \& Steiker, supra note 16, at 410 . Interestingly, far from being limited to the southern states that most strongly supported capital punishment, the backlash against Furman took place "all over the country: in abolitionist states, in de facto abolitionist states, and in death penalty states." Zimring \& Hawkins, supra note 10 , at $42-43$. All but three of the thirty-five states that authorized capital punishment prior to Furman reenacted their laws, the exceptions being the District of Columbia, Kansas, and Massachusetts. Id. at 43 tbl.2.8. It was not until the "war on drugs" in the 1980 s that Congress enacted a revised death penalty procedure. See Anti-Drug Abuse Act of 1988, 21 U.S.C. $\$ 848(e)-(r)(2000)$. For an excellent treatment of the backlash against Furman, see Corinna Barrett Lain, Furman Fundamentals, 82 Wash. L. Rev. 1, 45-55 (2007).

${ }^{19}$ See Zimring \& Hawkins, supra note 10 , at 42. 
legislatures in reenacting their death penalty statutes led the Supreme Court, in a string of decisions handed down in 1976, to allow executions to resume under the new statutes. ${ }^{20}$

This momentum toward reinvigorating capital punishment increased the visibility of prosecutorial behavior. Under pre-Furman capital statutes, prosecutors were only responsible for proving guilt; juries decided on their own whether or not death should be imposed. ${ }^{21}$ Not so, however, under the statutes redrafted in Furman's wake. Those statutes typically require prosecutors to put the death penalty in play by charging and proving legislatively specified factors that render defendants eligible for, and deserving of, death. ${ }^{22}$ In order for the death penalty to be available upon conviction, prosecutors have to make the case for death, both in their charging documents and in their evidence and argument at sentencing. ${ }^{23}$ Thus, prosecutors who previously could leave the allimportant penalty question to juries now bear personal responsibility for when and how often the death penalty is used.

As explored in greater detail in Part II, the results were as predictable as they are striking. Within a few short years of Furman, the floodgates had opened: "After a slow start in 1973, death sentences hit a three-decade high of 149 in 1974. In 1975, a whopping 298 death sentences were imposed-at the time, the highest year-

\footnotetext{
${ }^{20}$ See Gregg v. Georgia, 428 U.S. 153, 207 (1976); Proffitt v. Florida, 428 U.S. 242, 259-60 (1976); Jurek v. Texas, 428 U.S. 262, 276 (1976). In Gregg, the Court acknowledged that its decision to allow executions to resume was heavily influenced by the legislative backlash against Furman. Citing "developments during the four years since Furman," the Court stated that "it is now evident that a large proportion of American society continues to regard [the death penalty] as an appropriate and necessary criminal sanction." Gregg, 428 U.S. at 179.

${ }^{21}$ Indeed, there was surprisingly little prosecutors could do prior to Furman to influence the jury's life/death determination: "When Furman was decided, most states did not allow a broad presentation of mitigating and aggravating evidence beyond that necessary to determine the guilt question." Scott W. Howe, The Futile Quest for Racial Neutrality in Capital Selection and the Eighth Amendment Argument for Abolition Based on Unconscious Racial Discrimination, 45 Wm. \& Mary L. Rev. 2083, 2106 n.93 (2004).

${ }^{22}$ In "most states" that allow capital punishment, the "narrowing" requirement is satisfied by having a prescribed list of aggravating factors for juries to consider, at least one of which must be found to exist in a given case before death can be imposed. Lowenfield v. Phelps, 484 U.S. 231, 244 (1988).

${ }^{23}$ See generally Steven Semeraro, Responsibility in Capital Sentencing, 39 San Diego L. Rev. 79, 115-16 (2002) (explaining how post-Furman doctrine makes prosecutors responsible for the use of the death penalty).
} 
end figure ever recorded." ${ }^{24}$ Moreover, these death sentences would actually be carried out unless overturned in court because governors became very reluctant after Furman to commute death sentences. ${ }^{25}$ Death, in short, was back with a vengeance.

Despite year-to-year variation, the death penalty remains a staple of contemporary American criminal justice. As of 2004, there were more than three thousand people on death row nationwide. ${ }^{26}$ In 2005, the number of people executed since Furman crossed the one thousand mark. ${ }^{27}$ Execution figures of this magnitude would have been unthinkable in the years prior to Furman.

\section{B. Popularity of Capital Punishment}

As the number of executions declined in the decades leading up to Furman, so did public support for the death penalty. Polls reported a twenty-five percent decline in public support for capital punishment from 1953 to $1966 .^{28}$ In 1966 , public opposition to the death penalty reached the tipping point, with fifty-three percent of people surveyed opposing capital punishment. ${ }^{29}$ For the remainder of the 1960s and early 1970s, the death penalty enjoyed majority support, but opposition "remained high," ranging from a low of forty percent in 1967 to a high of forty-six percent in $1971 .^{30}$

${ }^{24}$ Lain, supra note 18 , at 48 .

${ }^{25}$ See discussion infra notes $129-152$ and accompanying text.

${ }^{26}$ See Thomas P. Bonczar \& Tracy L. Snell, Capital Punishment, 2004, 2005 Bureau of Just. Stat. Bull. 1, http://www.ojp.usdoj.gov/bjs/abstract/cp04.htm ("At yearend 2004, 36 States and the Federal prison system held 3,314 prisoners under sentence of death ....").

${ }^{27}$ See Brenda Goodman, North Carolina Man Is 1,000th Person Executed Since 1976, N.Y. Times, Dec. 3, 2005, at A17. The growth in the death-row population has slowed recently. Over the last three years for which data are available (2003 to 2005), the number of new death sentences has declined. See Tracy L. Snell, Capital Punishment, 2005, 2006 Bureau of Just. Stat. Bull. 8, http://www.ojp.usdoj.gov/bjs/pub/pdf/cp05.pdf. Tracy Snell, the Bureau of Justice Statistics researcher who prepares the Bureau's annual capital punishment reports, has attributed these declines to "a US murder rate that is at its lowest for 40 years." US Reports Decline in Executions, BBC News, Nov. 14, 2005, http://news.bbc.co.uk/2/hi/americas/4436168.stm.

${ }^{28}$ Zimring \& Hawkins, supra note 10 , at 39 ; see also id. at 39 tbl.2.7 (reporting annual poll results from 1953 to 1974).

${ }^{29}$ Id.

${ }^{30}$ Id. 
After Furman, anti-death penalty sentiment plummeted. Polls taken after the Furman decision showed a "dramatic decline" in the percentage of voters who opposed capital punishment. ${ }^{31}$ In 1973, just one year after Furman - a period in which the decision was relentlessly attacked by politicians and extensively covered in the media ${ }^{32}$-almost two-thirds of those surveyed supported the death penalty. ${ }^{33}$ Over the ensuing quarter century, polls "have consistently shown public support for capital punishment between sixty-five and eighty-five percent." ${ }^{34}$

In addition, the national backlash against Furman added fuel to the fires of efforts by President Richard M. Nixon and his Republican successors to move the Supreme Court to the right on criminal justice issues. The result was a sustained (and remarkably effective) effort by the so-called "law and order" Justices who came to dominate the Court to curtail drastically federal habeas corpus for state prisoners, ${ }^{35}$ a move which had enormous implications for capital punishment. The Furman vision of a death penalty that is both

\footnotetext{
${ }^{31}$ Id. at 39.

${ }^{32}$ See Lain, supra note 18 , at $46-55$.

${ }^{33}$ Zimring \& Hawkins, supra note 10, at 39 tbl.2.7. The cause of the stunning rise in the popularity of the death penalty is a matter of some dispute. Some scholars contend that increased crime rates during the 1960 s and 1970 s led to more punitive attitudes toward crime that drove up support for the death penalty quite apart from the impact of Furman. See, e.g., Joseph H. Rankin, Changing Attitudes Toward Capital Punishment, 58 Soc. Forces 194, 204 (1979). Although this causal story undoubtedly explains the rise of other punitive sentencing policies during this period, the best evidence suggests that it was "negative public reaction to the [Furman] decision itself" that made the death penalty so popular after 1972 . Lain, supra note 18 , at 50 . As Pro-
} fessor Lain has written:

[S]everal considerations cast doubt on th[e] [rising-crime-rates] hypothesis. First, crime rates had risen before Furman as well, with little to no effect on death penalty support. Second, the crime rate actually dropped in 1976, while support for the death penalty skyrocketed. Fmally, crime had begun to occupy the public consciousness as early as 1966 , when pollsters named it the nation's second most important domestic problem and President [Lyndon B.] Johnson issued a special message to Congress on the topic. That same year, however, marked the lowest level of death penalty support in recorded history, with death penalty opponents outnumbering its supporters.

Id. at 49-50 (footnotes omitted).

${ }^{34}$ Joshua Marquis, The Myth of Innocence, 95 J. Crim. L. \& Criminology 501, 519 (2005) (citing polling data).

${ }^{35}$ For an overview of the Supreme Court's steady retrenchment on federal habeas corpus review, see Stephen F. Smith, Activism as Restraint: Lessons from Criminal Procedure, 80 Tex. L. Rev. 1057, 1069-77 (2002). 
outwardly rational and accurately and fairly administered could not be achieved without close supervision by the federal courts of the administration of the death penalty in the states-supervision which, as a practical matter, could only come from searching habeas corpus review. ${ }^{36}$ As Professor James Liebman has explained, less stringent habeas review by the federal courts over the decades after Furman led to "skyrocketing executions." 37

The strong popular support for the death penalty that fueled the demise of searching habeas review has continued to the present day. By 1994, roughly eighty percent of Americans favored capital punishment. ${ }^{38}$ More recent polling data show a modest decline in support for the death penalty, but, as one would expect in the post9/11 era, support remains strong, hovering near seventy percent. ${ }^{39}$

\footnotetext{
${ }^{36}$ Docket constraints prevent the Supreme Court from single-handedly overseeing the administration of justice in state criminal cases nationwide. The virtue of broad access to habeas corpus was that it enlisted the lower federal courts in the resourceintensive effort to review state court convictions and sentences for compliance with federal constitutional mandates. See id. at 1063 n.30 ("[H]abeas corpus allows the lower federal courts to perform the review functions that docket constraints prevent the Supreme Court from performing on certiorari directly from the state-court systems.").

${ }^{37}$ James S. Liebman, The Overproduction of Death, 100 Colum. L. Rev. 2030, 204647 (2000). The number of executions conducted last year declined to forty-two, the lowest since 1994. See Dan Frosch, Executions in U.S. Decline to 13-Year Low, Study Finds, N.Y. Times, Dec. 19, 2007, at A20. The decline was primarily the result of ongoing challenges to the constitutionality of the most common method of execution, lethal injection-challenges the Supreme Court agreed, on September 25, 2007, to hear. Id. Although some executions were allowed to take place earlier in the year, the Court's decision to take up the challenges to lethal injection "caus[ed] a de facto moratorium on executions." Id.

${ }^{38}$ See Bohm, supra note 8, at 27; id. at 31 ("Between 1966 and 2002 ... support of the death penalty increased 30 percentage points, while opposition decreased 22 percentage points.").

${ }^{39}$ See supra note 34 and accompanying text. Interestingly, as traumatic as the $9 / 11$ attacks were, they did not have as great an impact on views about the death penalty as one might have expected. The attacks did boost support for capital punishment, but apparently not by much. See Sara Sun Beale, Still Tough on Crime? Prospects for Restorative Justice in the United States, 2003 Utah L. Rev. 413, 434-35 \& n.144 (discussing post-9/11 polling data). Some would argue that poll results like the ones previously cited overstate support for the death penalty because the gap between death penalty supporters and opponents shrinks when respondents are given the alternative of life imprisonment without possibility of parole. See Bohm, supra note 8, at 44-45. Even when life without parole is an alternative, however, most Americans still support capital punishment. See Jeffrey M. Jones, Support for the Death Penalty Re-
} 
This is so despite a growing recognition that people have been convicted and, in some cases, sentenced to death for crimes they did not commit. ${ }^{40}$ Despite the risks involved, "by a two-to-one margin, Americans say the death penalty is not imposed enough rather than imposed too often. ${ }^{41}$

\section{DEATH'S POLITICS}

The visibility and popularity of capital punishment after Furman are the engines that drive the politics of death. With strong public support for capital punishment and an expectation, especially in key "death" states like Texas and Virginia, that the death penalty will be imposed and carried out with some regularity, the institutional repeat players in the capital punishment "game"legislators, prosecutors, governors, and judges-have strong incentives to grease the skids of death by making death sentences easier to obtain and more likely to be executed once imposed. These political forces have resulted in more frequent, and less fair, application of the death penalty.

This Part explains the politics of death by surveying the institutional forces that operate on the various officials responsible for the implementation of the death penalty. The first three Sections address the incentives facing legislators, prosecutors and governors, and judges, respectively. As these Sections show, across the country, in states with varying degrees of intensity of support for capital punishment, these officials routinely exercise their authority in ways that allow broader and more frequent application of the death penalty. They do this not because the public wants them to, but rather out of rational self-interest in a climate of strong public support for the concept of capital punishment.

The fourth and final Section of this Part addresses the serious implications that the politics of death have for the administration of the death penalty. A "politicized" death penalty-the kind of death penalty America has had since Furman-is, first and fore-

\footnotetext{
mains High at $74 \%$, Gallup News Service, May 19, 2003, http://www.gallup.com/poll/8419/Support-Death-Penalty-Remains-High-74.aspx.

${ }^{40}$ As a 2003 Gallup poll found, "[t]wo in three Americans who favor the death penalty for murder believe that innocent people have been executed in the last five years." Jones, supra note 39.

${ }^{41}$ Id. (reporting findings of May 2003 Gallup polling).
} 
most, one that will be frequently carried out. Execution rates since the 1970 s make that clear. ${ }^{42}$ Less clear, yet perhaps even more important, is that a politicized death penalty is one that will often be unfairly and discriminatorily applied. The ultimate legacy of the politics of death thus is not just consistently high execution rates, but also unreliable, error-prone determinations of who deserves to die.

\section{A. Legislative Incentives}

At first blush, it might seem that, even in the states that most actively enforce the death penalty, capital punishment affords limited political benefits for legislators. Once death has been authorized for a particular crime and a constitutionally valid capital sentencing scheme enacted, legislators' involvement in the death penalty would seem to be at an end. From that point on, any further gains to be obtained from a public that favors capital punishment would apparently be available only to prosecutors and elected state judges, who collectively determine how often and upon whom the ultimate sanction is imposed. In fact, however, legislatures have continuous opportunities to expand the scope of capital punishment, and they regularly avail themselves of those opportunities because of the political incentives created by the visibility and popularity of the death penalty. This Section discusses several ways in which the politics of death have driven the actions of the nation's legislatures.

\section{Substantive Criminal Law}

Given the visibility and popularity of the death penalty, there is always mileage to be gained from enacting new capital crimes. In the wake of the terrorist attack on the Pentagon in Northern Virginia on September 11, 2001, the Virginia General Assembly created a new crime-murder in furtherance of terrorism-and made that crime punishable by death. ${ }^{43}$ It did not matter that terroristic acts of murder such as those committed by the $9 / 11$ attackers were

\footnotetext{
${ }^{42}$ See supra notes 24-27 and accompanying text.

${ }^{43}$ Act of Apr. 6, 2002, ch. 588, § 1, 2002 Va. Acts 810, 811, and Act of Apr. 6, 2002, ch. $623, \S 1,2002$ Va. Acts. 883, 885 (codified at Va. Code Ann. $§ 18.2-31(13)$ (2004)).
} 
already capital crimes in Virginia. ${ }^{44}$ What did matter was that legislators had an opportunity to use the death penalty to show their constituents that they were taking a tough stand on terrorism.

New capital crimes can also be created by increasing the penalty for existing noncapital crimes. Federal law offers a number of recent examples of this phenomenon. For example, in 1988 Congress added death as a possible penalty for so-called "drug kingpins.",45 Six years later, Congress passed the Federal Death Penalty Act of $1994,{ }^{46}$ which authorized capital punishment for more than fifty preexisting federal crimes that had been subject to lesser punishments, including kidnapping and carjacking. ${ }^{47}$ Although, in each case, Congress was addressing activities that were already serious federal crimes, the death penalty had enough political salience as a signal of "toughness" to lead Congress to deem it worthwhile to revisit them.

In addition to extending the scope of the death penalty, legislators can change the substantive law in ways that will increase the number of cases in which death will actually be imposed. Broadening the definition of death eligibility is one such change. The most common means of narrowing the sentencer's discretion to impose death is by defining aggravating circumstances that, if present in a particular capital case, indicate that death may be appropriate. ${ }^{48} \mathrm{By}$ expanding the number of aggravating factors recognized in capital sentencing statutes, legislatures can expand the number of cases in which death can and will be imposed, and, not surprisingly, legislatures have done just that. In 2005 alone, for example, the Arizona

\footnotetext{
${ }^{44}$ Prior to 2001, the list of offenses punishable by death in Virginia already included "the willful, deliberate, and premeditated killing of more than one person as a part of the same act or transaction." Va. Code Ann. \$18.2-31(7) (2004). That provision alone easily covers the $9 / 11$ attacks and other murders for purposes of terrorism. There are also other preexisting forms of capital homicide that would cover smaller-scale terroristic acts of murder. See, e.g., id. $\$ 18.2-31(8)$ (making it a capital offense to murder "more than one person within a three-year period").

${ }^{45}$ Anti-Drug Abuse Act of 1988, Pub. L. No. 100-690, § 7001, 102 Stat. 4181, 4387 (codified as amended at 21 U.S.C. $\$ 848(\mathrm{e})(1)(\mathrm{A})(2000)$ ).

${ }^{46}$ Pub. L. No. 103-322, § 60002(a), 108 Stat. 1796, 1959-68 (1994) (codified as amended at 18 U.S.C. $\$ 3591(2000)$ ).

${ }^{47}$ Id. $\S 60003$, 108 Stat. at $1968-70$ (codified as amended in scattered sections of 18 U.S.C.)

${ }^{48}$ See supra note 22 .
} 
legislature enacted four new aggravating factors. ${ }^{49}$ Not only do "definitions of capital murder remain extraordinarily broad," but legislatures have recognized a laundry list of aggravating factors. ${ }^{50}$

As these examples show, there is no dearth of opportunities for legislators to capitalize on persistently high levels of public support for capital punishment. The visibility of the death penalty and its unsurpassed power as a signal of "toughness" gives legislators strong incentives to take advantage of those opportunities. As repeated legislative expansions of the death penalty suggest, legislators are fairly quick to act on those incentives.

Note, however, that voters are not the only relevant interest group for legislators. In the area of criminal justice, prosecutors and police are powerful interest groups, and legislators benefit from having their endorsements (or at least avoiding their opposition) at reelection time. Legislators, therefore, will have incentives to reform the death penalty in ways that will appeal to police and prosecutors even if voters do not notice, or attach little or no value to, those reforms. For example, the public may or may not notice if a murder victim's status as a police officer is added as an aggravating factor in the capital sentencing scheme, but police groups certainly will. It is little wonder, then, that victim status as a peace officer is "one of the most common capital punishment aggravating

\footnotetext{
${ }^{49}$ See Tracy L. Snell, Capital Punishment, 2005, 2006 Bureau of Just. Stat. Bull. 2, http://www.ojp.gov/bjs/pub/pdf/cp05.pdf.

${ }^{50}$ Steiker \& Steiker, supra note 16, at 374. As Professors Steiker and Steiker note, "[s]everal states have enumerated ten or more aggravating circumstances, each individually sufficient to support a capital sentence." Id. In a fascinating recent essay, Jonathan Simon and Christina Spaulding show that adding new aggravating circumstances to criminal codes has become a cottage industry in "death" states. See Jonathan Simon \& Christina Spaulding, Tokens of Our Esteem: Aggravating Factors in the Era of Deregulated Death Penalties, in The Killing State: Capital Punishment in Law, Politics, and Culture 81, 81-113 (Austin Sarat ed., 1999). The result, they contend, is not just more, but qualitatively different, aggravating circumstances. The aggravating factors enacted in the immediate wake of Furman represented a serious effort by legislatures to identify the factors that make some killings more deserving of the ultimate sanction than others. Id. at 83-85. Contemporary aggravating factors, however, often represent efforts to capitalize on media-induced fear of the crime du jour or to send "tokens of our esteem" to "placate or reward special interest groups." Id. at 100 . Among the many examples offered by Simon and Spaulding is the nationwide rush to add carjacking and gang affiliation as aggravating circumstances in the wake of frenzied media reports. Id. at 97 . Their best example, however, may be Louisiana's 1995 law making it an aggravating circumstance that a killing was committed during a satanic ritual. Id. at 96-97.
} 
circumstances." ${ }^{51}$ Thus, as long as capital punishment is authorized, legislators will have incentives to expand the scope of the death penalty and to make it easier to impose in cases where it is sought.

This is not to suggest that the politics of death are immune from the influence of democracy. If there is overwhelming opposition to capital punishment among voters, then legislators may have the latitude to support limits on the death penalty, or even abolish it altogether. This is what recently happened in New Jersey: in December 2007, the state took the historic step of abolishing capital punishment. $^{52}$

Predictably, the move was hailed as an act of political courage, ${ }^{53}$ but far more than courage was at work. In New Jersey-which has long been weak in its support for capital punishment ${ }^{54}$-most voters oppose the death penalty. According to a 2007 poll by Quinnipiac University, the percentage of the state's residents who favor life imprisonment without parole over the death penalty increased six percentage points to fifty-one percent, with only forty-one percent favoring retention of capital punishment. ${ }^{55}$ Even before then, New

${ }^{51}$ See James R. Acker \& C.S. Lanier, "Parsing This Lexicon of Death": Aggravating Factors in Capital Sentencing Statutes, 30 Crim. L. Bull. 107, 143 (1994). See generally id. at 143-46 (discussing "peace officer" aggravation statutes).

${ }^{52}$ See Jeremy W. Peters, Corzine Signs Bill Ending Executions, Then Commutes Sentences of 8, N.Y. Times, Dec. 18, 2007, at B3.

${ }^{53}$ See, e.g., Editorial, A Long Time Coming, N.Y. Times, Dec. 15, 2007, at A34 (stating that "it took political courage for lawmakers to join with Governor [Jon S.] Corzine [in repealing the death penalty]" and that their courageous example "could prick the conscience of elected officials in other states").

${ }^{54}$ Even during the nationwide stampede to reinstate the death penalty after Furman, New Jersey was very slow to act. Dozens of states had reenacted their capital punishment laws by 1975 . See supra note 18 . New Jersey, however, did not follow suit until 1982-and, even then, has never executed anyone sentenced to death in the post-Furman era. See Despite Supreme Court Ruling, Execution Still Remains Distant, Buck County Courier Times, July 29, 2006, at C3. The last execution in the state took place in 1963 . Id. When New Jersey abolished the death penalty in 2007 , only eight people were on death row statewide. See Peters, supra note 52. In light of these facts, New Jersey's move does not represent a trend away from capital punishment but rather a confirmation of what has been obvious for decades-namely, that New Jersey is out of the execution business.

${ }^{55}$ See Press Release, New Jerseyans for Alternatives to the Death Penalty, Quinnipiac Poll Finds Majority of New Jerseyans Favor Life Without Parole over the Death Penalty: Public Support Continues to Trend away from Executions (Jan. 24, 2007), http:/www.njadp.org/forms/uploads/newsup.2007-01-26_10:52:30.7561.html. The abolitionist sentiment was six percentage points higher than recorded in Quinnipiac's 2003 poll, its previous on the subject. Id. 
Jersey voters were sufficiently ambivalent about the death penalty that it had fallen into disuse since 1963, the date of the state's last execution. ${ }^{56}$ With such widespread voter opposition to capital punishment, ending the death penalty was largely symbolic, not the kind of action requiring profiles in courage.

Even the state's Republicans, in their losing battle last year to retain the death penalty, had to acknowledge they were swimming against the tide. Instead of seeking to retain the death penalty as an option for all first-degree murders, they sought only to preserve it for extreme cases involving terrorists, cop-killers, and child sexual predators. ${ }^{57}$ Although Republicans pushed all the right buttonsincluding the 9/11 attacks (in which New Jersey suffered the second-highest number of casualties) ${ }^{58}$ and the 1994 rape and murder of seven-year-old Megan Kanka, the little girl from New Jersey for whom "Megan's Laws" are named nationwide ${ }^{59}$-the opposition had become far too strong by 2007 to save the death penalty.

Properly understood, the New Jersey experience illustrates how powerful the politics of death are. New Jersey is the only state to abolish capital punishment over the last forty years. ${ }^{60}$ There is no indication that New Jersey's action is likely to inspire other states to follow suit, and nationally the death penalty enjoys far greater support than in New Jersey. ${ }^{11}$ Moreover, even a state like New Jersey, where support for the death penalty was unusually low and no execution had been conducted in decades, could not resist joining

\footnotetext{
${ }^{56}$ See supra note 54 . The fact that, de facto, New Jersey had already rejected capital punishment was a factor that a number of legislative supporters of the death penalty cited in voting to repeal the state's capital statutes.

${ }^{37}$ See Tom Hester, Jr., Some Decry N.J. Death Penalty Abolition, Associated Press, Dec. 18, 2007 ("The bill passed the legislature largely along party lines, with controlling Democrats supporting the abolition [of the death penalty] and Republicans opposed. Republicans unsuccessfully sought to retain the death penalty for those who murder law enforcement officials, terrorists and those who rape and murder children.")

${ }^{58}$ For state-by-state totals for the 9/11 attacks, see September 11, 2001 Victims, http://www.september11 victims.com/september11 victims/COUNTRY_CITIZENSHI P.htm (last visited Feb. 13, 2008).

${ }^{39}$ See Andy Newman, N.J. Law; Taking a Tougher Stand on Crime, N.Y. Times, Dec. 31, 1995, at NJ8 (discussing origins of New Jersey's Megan's Law).

${ }^{60}$ See Editorial, A Pause from Death, N.Y. Times, Dec. 20, 2007, at A42.

${ }^{61}$ See supra Section I.B. According to the New York Times, New Jersey's action "left much of this country underwhelmed" even as it garnered praise from the international community. Editorial, supra note 60.
} 
the Furman backlash in 1982, and it took more than two decades to abolish the death penalty. This shows the power of the politics of death: the political system kept the death penalty alive in the face of strong opposition, and it was only a surge in abolitionist sentiment that gave politicians the latitude formally to end capital punishment in New Jersey.

\section{Remedies and Funding}

The examples of the operation of death's politics offered thus far involve crime creation and grading. As to such matters, the pull of politics is, in one commentator's words, "pathological" in the sense that it "always pushes toward broader liability rules, and toward harsher sentences as well.".62 There are, however, other means through which legislators can, and do, rev up the machinery of death. Two are worth consideration here: limiting judicial remedies and underfunding indigent defense.

\section{a. Limiting Judicial Remedies}

Legislators can effectively facilitate the death penalty by restricting access to the courts. For obvious reasons, prisoners condemned to death have every incentive to pursue all available avenues of challenging their convictions or sentences. Due largely to the nature of death penalty jurisprudence-which many regard as "complex, arcane, and minutely detailed"63 - most death sentences are overturned at some point. ${ }^{64}$ The rate at which defendants convicted

\footnotetext{
${ }^{62}$ William J. Stuntz, The Pathological Politics of Criminal Law, 100 Mich. L. Rev. 505, 510 (2001). As Professor Stuntz demonstrates, broader liability rules (such as more expansive capital murder statutes) make it easier for prosecutors to carry their burden of proof. The more likely the prosecutor is to succeed at trial and the more severe the punishment the defendant faces in the event of conviction, the stronger the defendant's incentive to plead guilty (as the vast majority of defendants do) in hopes of obtaining a lesser sentence. See id. at 519-20.

${ }^{63}$ Steiker \& Steiker, supra note 16 , at 371.

${ }^{64}$ According to a recent study, "[f]or every 100 death sentences imposed and reviewed during the study period $[1973-1995], \ldots$ at least $68 \ldots$ were thrown out because of serious flaws." James S. Liebman et al., Capital Attrition: Error Rates in Capital Cases, 1973-1995, 78 Tex. L. Rev. 1839, 1852 (2000). Note that this error rate refers to the rate of reversible error. See id. The rate would be even higher if errors that were considered harmless or that defense counsel failed to preserve were counted.
} 
of noncapital crimes obtain reversal pales in comparison. ${ }^{65}$ Consequently, prisoners on death row are more likely to appeal, and more likely to have meritorious appeal issues, than other prisoners. This state of affairs provides legislatures with strong incentives to reduce the opportunities afforded capital defendants to seek judicial relief.

That is precisely what Congress had in mind when it enacted the Antiterrorism and Effective Death Penalty Act of 1996 ("AEDPA"). ${ }^{66}$ The title of the legislation said it all: the reason for drastically limiting the scope of federal habeas corpus was to make the death penalty more "effective." By "effective" Congress meant a death penalty that is expeditious and virtually impervious to attack in federal court. ${ }^{67}$ Among other significant provisions, the AEDPA imposed strict time limits on the filing of federal habeas corpus actions, ${ }^{68}$ gave preclusive effect to orders denying habeas relief, ${ }^{69}$ and essentially limited habeas corpus relief to bad faith or patently unreasonable state court errors. ${ }^{70}$

${ }^{65}$ By one account, prisoners sentenced to death are four times more likely to prevail on direct or collateral review than prisoners who received lesser punishments. Compare id. at 1852 (finding sixty-eight percent error rate in capital cases), with id. at 1854 \& n.49 (finding error rate in noncapital cases of no more than fifteen percent).

${ }^{66}$ Pub. L. No. 104-132, 110 Stat. 1214 (1996) (codified as amended in scattered sections of the U.S. Code).

${ }^{67}$ As harsh as it may sound, the legislative history leaves no doubt on this score. See Liebman, supra note 37, at 2047 n.79.

${ }^{68}$ See 28 U.S.C. $\$ 2244$ (d)(1) (2000) (prescribing a one-year limitations period for habeas petitions).

${ }^{69}$ See id. $\$ 2244$ (b) (providing for dismissal of claims that were raised, or could have been raised, in prior habeas petitions).

${ }^{70}$ See id. $\S 2254$ (d)(1) (providing that state court decisions cannot be reversed unless they were "contrary to, or involved an unreasonable application of, clearly established Federal law, as determined by the Supreme Court of the United States"). State legislatures have done their part, too, to narrow the doors to the courthouse. See Liebman et al., supra note 64 , at $1841 \mathrm{n} .7$ (citing sources documenting efforts at the state level to increase the number and speed of state executions). For example, it is probably no accident that two of the states with the highest number of executions, Texas and Virginia, traditionally imposed the most stringent restrictions on the introduction of new evidence of innocence. Convicted prisoners had thirty days in Texas, and a mere twenty-one days in Virginia, to discover and proffer new evidence. See Tex. R. App. P. 21.4(a); Va. Sup. Ct. R. 3A:15(b) (repealed in part in 2001). Evidence discovered outside of those periods was ruled inadmissible, no matter how probative of actual innocence. See Va. Sup. Ct. R. 3A:15(b) (repealed in part in 2001). The Supreme Court upheld Texas's rule in Herrera $v$. Collins, 506 U.S. 390, 411 (1993). Virginia recently repealed its infamous "21-day rule" under withering criticism fueled by the dis- 


\section{b. The Funding "Squeeze"}

Perhaps the single most important means through which legislators facilitate the death penalty is to allocate funding strategically in ways that systematically favor prosecutors over indigent defendants. This strategy is a useful one for legislatures in all criminal cases, ${ }^{71}$ but it is especially useful in capital cases. This is due to the nature of capital cases after Furman and its progeny.

As the high reversal rate in capital cases suggests, ${ }^{72}$ death penalty cases are among the most difficult cases to litigate. Typically, there are two trials, not just one: a trial on guilt or innocence and, in the event of a guilty verdict, a full-blown trial on whether or not death should be imposed. Unlike more conventional criminal trials, in which the trial focuses on a discrete set of facts pertaining to the commission of the crime, the range of facts potentially implicated in a capital sentencing trial is virtually limitless, encompassing quite literally the entire life of the defendant. The life-or-death decision may hinge on factors as varied as the defendant's family background, his performance as a child in school, his history of physical or sexual abuse as a youth, his mental health history, his criminal record and the nature of any prior crimes he committed, and his behavior while incarcerated. ${ }^{73}$ Defense lawyers, in short, will have many areas to mine in search for reasons that jurors should spare their clients' lives.

Given the sad demographics of death row, there will often be reasons for leniency even in cases of brutal, senseless killings. For instance, many people sentenced to die are mentally ill or brain-

covery that a prisoner named Earl Washington had come within nine days of being executed for a murder he did not commit. Virginia law now allows prisoners to file "writs of actual innocence" based on DNA evidence without time limit. See Va. Code Ann. \$ 19.2-327.2 (2004); see also Michael Hardy, Governor Relaxes State's "21-Day Rule," Rich. Times-Dispatch, May 3, 2001, at B1. A similar recent enactment in Texas, which authorizes new trials for inmates who present newly-discovered "material evidence" of innocence, has been construed as subject to the thirty-day limitations rule upheld in Herrera. See, e.g., In re R.V., Jr., 8 S.W.3d 692, 693 (Tex. App. 1999) (construing Tex. Code Crim. Proc. Ann. art. 40.001 (Vernon Supp. 2000)).

${ }^{11}$ See William J. Stuntz, The Uneasy Relationship Between Criminal Procedure and Criminal Justice, 107 Yale L.J. 1, 7-10 (1997).

${ }^{72}$ See Liebman, supra note 64, at 1852 .

${ }^{73}$ The Constitution requires that capital defendants be allowed to present any relevant evidence in mitigation at the sentencing phase. See, e.g., Lockett v. Ohio, 438 U.S. 586, 604-05 (1978). 
damaged, or suffered severe physical, sexual, and emotional abuse as children. ${ }^{74}$ Defense lawyers, therefore, will often have lots to work with in putting together a plausible mitigation case at a capital sentencing hearing- $i f$, that is, they have the time and resources necessary to do a thorough investigation into the relevant facts.

This is where legislative funding strategy comes into play. Legislatures, with their "power of the purse," gladly fund law enforcement because every dollar spent on police and prosecutors is a dollar spent promoting outcomes that legislatures (and voters) favor: solving crimes and punishing the individuals who committed them. Not so with funding for indigent defense. After all, such funding makes it harder for prosecutors to win convictions against guilty defendants, who, with the aid of a defense attorney, may "get off" on the proverbial "technicality." 75

The patchwork of constitutional rules governing entitlement to state-funded legal representation creates ample opportunities for determined legislatures to tilt the scales in favor of death. As an

${ }^{74}$ It has been estimated that five to ten percent of the more than 3000 inmates on death row have serious mental illnesses. See Nat'l Mental Health Ass'n, Death Penalty and People with Mental Illness, http:/www1.nmha.org/position/deathPenalty/deathpenalty.cfm. Brain damage also is reported to be common among individuals sentenced to death. See, e.g., Laura Mansnerus, Damaged Brains and the Death Penalty, N.Y. Times, July 21, 2001, at B9 ("Almost without exception, Dr. [Dorothy Otnow] Lewis has found in evaluating dozens of death-row inmates, they have damaged brains. Most were also the victims of vicious batterings and often sexual abuse as children. Psychotic symptoms, especially paranoia, are common."). So, too, is severe physical and sexual abuse in childhood: "The kinds of childhood abuse and their long-term effects documented in the psychological and medical literature are evident among defendants on death row. Many death penalty cases involve defendants who were physically, sexually, and/or psychologically abused." Phyllis L. Crocker, Childhood Abuse and Adult Murder: Implications for the Death Penalty, 77 N.C. L. Rev. 1143, 1166-67 (1999) (footnotes omitted). See generally id. at 1174 \& n.125 (citing research documenting "extensive histories of mental disorders, neurological impairments, and childhood physical or sexual abuse"). Many condemned prisoners suffer from a combination of these factors. Id. at 1172-74.

${ }^{75}$ In fact, states only rarely provided such funding until forced to do so by the Supreme Court. In a series of cases, the Court ruled that due process mandated appointment of counsel for indigent defendants in all prosecutions, capital and noncapital alike, where "special circumstances" made defense representation essential to a fair trial. See, e.g., Betts v. Brady, 316 U.S. 455, 473 (1942), overruled by Gideon v. Wainwright, 372 U.S. 335 (1963); Powell v. Alabama, 287 U.S. 45,71 (1932), Gideon rejected the case-by-case "special circumstances" approach in favor of a rule that poor defendants charged with felonies are automatically entitled to state-funded representation. 372 U.S. at 344-45. 
example, consider the right to counsel. Since the early 1960s, indigent defendants charged with capital crimes have had an automatic right to state-funded legal representation at trial. ${ }^{76}$ Nevertheless, the Constitution does not regulate the means through which states fulfill their obligation to provide legal representation for indigents. In urban areas, states usually opt for public defender offices in which the government hires lawyers for the purpose of representing indigent defendants on a full-time basis. There is, however, no constitutional regulation of staffing levels and caseloads beyond the generally applicable requirement that criminal defendants are entitled to "effective" representation." As a result, public defender offices are notoriously underfunded and understaffed, leaving public defenders saddled with crushing caseloads. ${ }^{78}$ Heavy caseloads force public defenders to ration their time among their many clients, creating the danger that clients will receive far less attorney time and attention than their cases merit or be pressured into pleading guilty.

The situation is no better in jurisdictions without public defender offices. Indeed, in some respects, it is worse. By virtue of their specialization in criminal law, public defenders quickly develop considerable expertise in their fields. That is not necessarily the case with appointed counsel, who often have practices principally devoted to other kinds of matters and use appointed criminal cases merely to supplement their income. ${ }^{79}$

Moreover, as with public defenders, legislatures have used funding constraints to hamper the quality of representation appointed lawyers provide their clients. The fees for court-appointed cases are usually capped, often at unrealistically low levels that cannot be waived by trial judges. ${ }^{80}$ Low fees can have adverse selection effects, leading the best-qualified defense attorneys to opt out of the system in favor of more remunerative cases. ${ }^{81}$ Capped fees also cre-

\footnotetext{
${ }^{76}$ See Hamilton v. Alabama, 368 U.S. 52, 55 (1961) (capital cases); see also Gideon v. Wainwright, 372 U.S. 335, 34445 (1963) (all felony cases).

${ }^{77}$ See Strickland v. Washington, 466 U.S. 668, 684-85 (1984).

${ }^{78}$ See generally Richard Klein \& Robert Spangenberg, The Indigent Defense Crisis, 1993 A.B.A. Sec. Crim. Just. 3-9.

${ }^{79}$ See id. at 7.

${ }^{80}$ See id. at 5-6.

${ }^{81}$ See id. at 5 . To see the adverse effect this can have on the quality of justice, consider the following report from Texas: "The roster of attorneys who have defended
} 
ate incentives for those attorneys who continue doing courtappointed work to make up for the low fees available in individual cases by taking on a high volume of cases. Such attorneys often find themselves in the same situation as hopelessly overburdened public defenders. ${ }^{82}$

Consider, for example, the results of an exhaustive study of Virginia's system for indigent defense representation commissioned by the American Bar Association. ${ }^{83}$ On every funding-related matter surveyed, Virginia prosecutors came out far ahead of public defenders. These include attorney salaries and caseloads, ${ }^{84}$ attorney and support staff, ${ }^{85}$ and office resources. ${ }^{86}$ Virginia's beleaguered public defenders carry, on average, over five hundred cases annually, a caseload that not only "exceeds that permitted in most other public defender programs in the country" but also, in the words of

the 131 men and women executed under [Governor George W.] Bush includes convicted felons, disbarred and suspended lawyers, and attorneys who were inexperienced or whose work was inept." Steve Mills et al., Flawed Trials Lead to Death Chamber, Chi. Trib., June 11, 2000, at 1. "At least 43 of those [executed prisoners] were represented at trial or on their initial appeal by a lawyer who had been or was later publicly sanctioned for misconduct by the State Bar of Texas .... In 34 of those 43 cases, the sanctioned attorney was disbarred, suspended or given what is called a 'probated suspension."' Id.

${ }^{82}$ See Klein \& Spangenberg, supra note 78 , at 6.

${ }^{83}$ The Spangenberg Group, A Comprehensive Review of Indigent Defense in Virginia (2004) (reporting results of research conducted on behalf of the American Bar Association's Standing Committee on Legal Aid and Indigent Defendants).

${ }^{84}$ See, e.g., id. at 34 ("In Virginia Beach, there is a $\$ 15,000$ disparity in starting pay for assistant Commonweaith's attorneys and assistant public defenders. Further, there are 57 assistant commonwealth attorneys, compared to 34 assistant public defenders."); id. ("Although they are both state-created and funded positions, and although both work on the same cases, Commonwealth's attorneys and public defenders are not paid on par with one another. Across the board, from entry level to the most senior positions, attorneys working as Commonwealth's attorneys earn moresometimes significantly more-than public defenders in like jobs.").

${ }^{85}$ See id. at 36 ("All public defender offices have investigators and secretaries on staff, however the number of support positions is very few compared to those in Commonwealth's attorney offices. For example, the Richmond Commonwealth's Attorney's office has 37 attorneys and 35 support staff compared to the Public Defender Office's 20 attorneys and 10 support staff.").

${ }^{86}$ See id. at 37 ("Virginia's public defender offices lack the most basic equipment necessary to run a modern law office. Investigators, in particular, lack the toois necessary to conduct and document investigations and prepare for presentations in court. Further, public defender offices receive no funds for basic litigation expenses, such as having photocopies made of crime records."). 
one assistant public defender, often results in representation that "verges on malpractice." 87

This is a picture that appointed lawyers would recognize from their own experiences representing indigents in Virginia. Virginia "has the lowest statutory caps in non-capital cases of any state in the nation." ${ }^{\prime 8}$ With such low caps-caps that, "unlike those in most states, are non-waiveable" ${ }^{\prime 89}$ - fewer attorneys are willing to accept court appointments. ${ }^{90}$ Those who do accept appointed cases tend to take on a large volume of cases as a supplement to their existing practices, spending the least amount of time possible on appointed cases. ${ }^{91}$

A similar dynamic plays out in capital cases in Virginia. Although there are no fee caps applicable to capital cases, fee recovery is very low. As one report has found, "after taking into account attorneys' overhead expenses, the effective annual hourly rate paid to Virginia counsel representing indigent capital defendants was \$13."

Severe constraints on attorney time are compounded by the fact that indigent defenders in Virginia are often denied funding for investigators or for DNA testing or other expert analysis and testi-

${ }^{87}$ Id. at 27-28; see also id. at 32 (concluding that the huge caseloads public defenders carry result in a "lack of client and family member contact, inability to do legal research, little or no motion practice, insufficient investigation in cases where investigators are not used, insufficient case and trial preparation, failure to prepare a presentence plan and, eventually, burnout").

${ }^{88}$ Id. at 45.

${ }^{89} \mathrm{Id}$.

${ }^{90}$ See id. at 52-53.

${ }^{91}$ See id. at $50-52$.

${ }^{92}$ Klein \& Spangenberg, supra note 78 , at 7 . As low as this effective rate of compensation is, it is positively generous compared to what appointed counsel in Texas receive:

According to a recent study by the State Bar of Texas' Committee on Legal Services to the Poor in Criminal Matters, the average overhead expenses for Texas criminal defense lawyers is $\$ 71.36$ per hour. Thus, the average criminal defense lawyer must be paid at or above that level just to "break even" for every hour that the lawyer works on a case. The vast majority of the counties in our study were compensating appointed counsel below the cost of hourly overhead expenses, meaning that appointed counsel was actually losing money for every hour that she worked on the case.

Tex. Appleseed Fair Def. Project, The Fair Defense Report: Analysis of Indigent Defense Practices in Texas 97 (2000) (footnote omitted), http://www.equaljusticecenter.org/ Fair\%20Defense\%20Reference\%20Report.pdf. 
mony that prosecutors take for granted. As a recent report put it, one of the most striking features of Virginia's system of indigent defense "is the complete inadequacy of access by public defenders and court-appointed counsel to court-approved experts and a similar inadequacy of access of court-appointed counsel to courtapproved investigators." 93

In this climate, it might be expected that Virginia would have an impressive win/loss record in capital cases. Even so, it is striking to find out just how impressive its record is. Virginia's "low rate of capital reversals is nearly half that of the next nearest state and less than one-fourth the national average," and its execution rate is "nearly double that of the next nearest state and five times the national average." $"$ Any number of potential explanations comes to mind for these phenomena. Virginia prosecutors may be exceptionally skilled in winning death sentences or exceptionally restrained in seeking the death penalty; alternatively, Virginia judges may be unusually reluctant to grant relief in capital cases. The unusually severe disparities between the funding and resources available to the prosecution and defense, however, likely have a lot to do with the exceptionally poor results death-row inmates achieve in Virginia courts.

\section{B. Incentives of Prosecutors (and Chief Executives)}

As the preceding discussion demonstrates, the ground rules set by legislatures in death penalty states will tend to be skewed in favor of death. Once those rules are set, the determination of how frequently death is sought and carried out when imposed is left to the discretion of prosecutors and chief executives (in the state sys-

\footnotetext{
${ }^{93}$ The Spangenberg Group, supra note 83 , at 59 . See generally id. at 59-72 (documenting the inability of indigent defenders to get the information necessary to mount an effective defense). Needless to say, Virginia is not alone in imposing severe constraints on the defense of indigents. For an excellent overview of the daunting resource challenges capital defenders face nationwide, see Douglas W. Vick, Poorhouse Justice: Underfunded Indigent Defense Services and Arbitrary Death Sentences, 43 Buff. L. Rev. 329, 377-97 (1995).

${ }^{94}$ Id. at 1858 (emphasis omitted). A mere ten percent, Virginia's rate of capital reversals is considerably lower than those of other leading "death" states, including Florida (49\%) and Texas (31\%). See James S. Liebman et al., A Broken System: Error Rates in Capital Cases, 1973-1995, at 53 tbl.4 (2000), http://www.thejusticeproject.org/press/reports/liebman-part-1.html.
} 
tem, governors, and at the federal level, the President). To understand the politics of death, therefore, it is necessary to explore the incentives of prosecutors and chief executives in the administration of society's ultimate sanction.

\section{Prosecutors}

In most states, prosecutors stand for election, just as legislators do. ${ }^{95}$ Prosecutors will therefore share the interest of legislators in signaling their "toughness" to voters in the area of crime and punishment, and the death penalty is uniquely powerful as a signal of that vital characteristic." Prosecutors signal their "toughness" through their charging decisions and the results they achieve in court. Because prosecutors decide whether to prosecute and what penalty to seek, and litigate the cases selected for prosecution, they bear personal responsibility for their handling of criminal prosecutions.

This fact has two important implications for the administration of the death penalty. First, it forces prosecutors to concentrate their resources on a smaller number of capital cases. Second, it gives prosecutors even stronger incentives to win in death penalty cases than in noncapital cases. Each of these implications is explored below.

\footnotetext{
${ }^{95}$ See Stuntz, supra note 62 , at 533.

${ }^{96}$ See generally Kenneth Bresler, Seeking Justice, Seeking Election, and Seeking the Death Penalty: The Ethics of Prosecutorial Candidates' Campaigning on Capital Convictions, 7 Geo. J. Legal Ethics 941 (1994). Kenneth Bresler discusses a "particularly gruesome campaign practice" of "prosecutors and former prosecutors politicking on the defendants they have sent to death row." Id. at 943 . He gives the following example:

[In 1990], the Attorney General of California, who was also the former District Attorney of Los Angeles County, ran for the Democratic nomination for Governor. He broadcast a commercial depicting the metal door to a gas chamber swinging open. A voiceover proclaimed, "As District Attorney and Attorney General, he's put or kept 277 murderers on death row." The opening door revealed the execution chair, its straps loose. Below the chair, a caption stated that the candidate had "Put or Kept 277 on Death Row."

Id. at 945 (footnote omitted).
} 


\section{a. Resource Concentration}

For most prosecutors, scarcity of resources is a fact of everyday life. There are far too many crimes on the books for prosecutors to charge each offender. Instead, prosecutors must allocate their resources carefully in order to maximize the deterrence they can get from the limited number of prosecutions they can bring.

A common strategy for stretching scarce prosecutorial resources is plea bargaining. Plea bargaining allows prosecutors to obtain convictions without incurring the burden and expense of trial: defendants waive their trial rights and consent to a conviction in exchange for sentencing or other concessions from the prosecutor. Over ninety percent of serious criminal cases nationwide end in guilty pleas, the majority of which result from plea bargains. ${ }^{97}$ High guilty-plea rates allow prosecutors to spread their scarce resources across a larger number of cases by charging (and convicting) more defendants than they could afford to take to trial.

This strategy does not work in cases where the prosecutor wants to put the defendant to death. In such cases, the prosecutor has nothing to offer the defendant as an inducement to plead guiltyand, as importantly, nothing to use as a threat to compel a recalcitrant defendant to plead guilty. To be sure, some defendants "volunteer" for the death penalty by acquiescing at some point in their fate, but the vast majority fight for a reprieve, both in the courts and in the clemency process, until the bitter end. ${ }^{98}$ Consequently, whereas prosecutors can be fairly confident that noncapital cases will not go to trial, they must assume that every capital case in which they insist on a sentence of death will result in a trial (and, in all likelihood, two trials: a trial on guilt followed, in the event of conviction, by another on sentencing) and several rounds of protracted appeals and postconviction review proceedings.

\footnotetext{
${ }^{97}$ See Bureau of Justice Statistics, Sourcebook of Criminal Justice Statistics-1995, at 498 (Kathleen Maguire \& Ann L. Pastore eds., 1996).

${ }^{98}$ See David A. Davis, Choosing Death: Florida's Treatment of Death Row Volunteers, 40 Crim. L. Bull. 260, 260 (2004) ("Since the states resumed executions in 1977, they have put to death 818 men and women. Among those, 95 , or about $12 \%$, had abandoned pursuing any litigation at some point. In death penalty jargon, they "volunteered' to be executed." (footnote omitted)). Presumably, most of these "volunteers" were like Timothy McVeigh, the Oklahoma City bomber, in that they originally fought to avoid a death sentence and only later, when their situation appeared hopeless, withdrew their appeals and accepted their fate. See Bragg, supra note 6.
} 
This state of affairs has two resource-concentration effects. First, it requires prosecutors to decide whether they are willing to endure protracted litigation in order to win, defend, and carry out a death sentence-a process that will likely take more than a decade. ${ }^{99}$ If they are not, then they should ordinarily decline to seek the death penalty. Sometimes, however, prosecutors will file capital charges even if they are not determined to obtain a death sentence. In these cases, the death penalty is intended only as a bargaining chip to be traded in exchange for a guilty plea. ${ }^{100}$ Second, in the cases in which prosecutors really do want a death sentence, prosecutors will commit to litigate for the many years it will probably take in order to put the defendant to death. In this way, the high likelihood that execution will be impossible without protracted litigation will effectively concentrate prosecutorial resources on a smaller number of capital cases.

The significance of resource concentration on the prosecution side in capital cases can be seen by comparing it to the conditions under which capital defenders are forced to operate. Whereas prosecutors will be able to invest considerable resources into the capital cases they file, indigent defenders will be outmatched by virtue of how badly underfunded indigent defense is nationwide. ${ }^{101}$

\footnotetext{
${ }^{99}$ Consider, for example, the amount of time it takes to carry out a death sentence: "Among prisoners executed from 1977 to 2004, the average time between the imposition of the most recent sentence received and execution was more than 10 years." Bonczar \& Snell, supra note 26, at 11. For the fifty-nine prisoners executed in 2004, the average wait time was slightly longer (eleven years). Id. at 1.

${ }^{100}$ This strategy has its limits. If the prosecution seeks the death penalty simply for bargaining leverage, then it may find itself compelled, as a practical matter, to pursue execution. The reason is that, wisely or not, some defendants may elect to take their chances at trial on a capital charge rather than agree to spend the rest of their lives behind bars. In that event, prosecutors will have no choice but to persist in their execution demand. To withdraw an execution demand in the wake of a rejected offer of life imprisonment would risk undermining the in terrorem effect of the death penalty in future plea negotiations. The defendant who rejects a plea offer, in other words, has to be punished so that future defendants will not repeat his mistake. See Bordenkircher v. Hayes, 434 U.S. 357 (1978) (ruling that it is constitutional for prosecutors to follow through on bargaining threats when defendants reject offers of leniency during plea negotiations).

${ }^{101}$ See supra notes $62-94$ and accompanying text. As one commentator has explained:

Prosecutors are not asked to endure the hardships that resource deprivation causes for the defense [in capital cases]. Prosecutors receive on average more than three times the funding that is provided to defenders in the United States,
} 
This is most apparent with appointed counsel. Lawyers who accept court appointments in criminal cases are typically solo practitioners or practice in small firms. Such lawyers are in no position to match the manpower and resources available to a prosecutor's office bent on obtaining a death sentence. Resource concentration, therefore, gives prosecutors a clear advantage over the typical court-appointed lawyer.

The effect of resource concentration on public defenders is different. Resource concentration actually benefits public defenders. It does so in the same way that it benefits prosecutors-by freeing up resources that would otherwise have been expended on additional capital cases. Even assuming that public defender offices would reallocate the saved resources to other capital cases (which is not at all clear given how significantly understaffed and underfunded public defenders are as compared to prosecutors), ${ }^{102}$ the effect on the quality of representation afforded is likely to be marginal. The unmet resource needs are simply too great. To the extent public defenders will, even with a boost from concentrated resources, be unable to match the manpower and resources that prosecutors' offices will be prepared to invest in capital cases, public defenders will be in a similar position to appointed lawyers. Thus, resource concentration in capital cases produces an even wider resource and effectiveness gap between the prosecution and defense teams.

\section{b. Avoiding Defeats}

As the individuals responsible for prosecuting criminal cases, prosecutors have strong incentives to make sure that the capital cases they file will end in convictions and, most of the time at Ieast, death sentences. Many criminal prosecutions are not significant enough to generate publicity, and in those cases, prosecutors have

and the differential is really much greater than that figure indicates. Funding for the support services essential to the preparation of the prosecutor's casepolice investigation, FBI and local crime labs, and state and local forensic experts-does not come out of the budget for the prosecutor's office, while analogous expenses by the defense must be paid out of the money provided for defense services.

Vick, supra note 93, at 394-95 (footnotes omitted).

${ }^{102}$ See Vick, supra note 93 , at 394-95. 
little to fear from a litigation defeat. Death penalty cases, however, do not fall into that category. Murders receive heavy coverage, even in large media markets, and death penalty trials can easily result in saturation coverage on television news programs and in local newspapers for weeks or months on end..$^{103}$ With such extensive coverage, prosecutorial losses in capital cases will not go unnoticed.

Naturally, such losses may be embarrassing to the prosecuting attorney, but far more is at stake than reputation alone. When the penalty phase ends in a life sentence, scarce prosecutorial resources will have been squandered in a quest that could probably have resulted in the same outcome with considerably less cost and effort. After all, many defendants would readily plead guilty to avoid the death penalty. ${ }^{104}$ For a prosecutor to take such defendants to trial and a capital hearing only to end up with a life sentence consumes resources that might have been better spent on other cases.

Of course, even if prosecutors litigate capital cases that end in life sentences, they can still take credit for having obtained a firstdegree murder conviction and for having been "tough" enough to ask for death. Nevertheless, in many cases, that may amount to little more than "spin control." Even if they later claim, in statements to the press or in campaign literature, to have been vindicated by a life sentence, many prosecutors consider anything other than a death sentence as a defeat. ${ }^{105}$

${ }^{103}$ These cases can be so heavily covered in the local media as to make it difficult to seat an impartial jury. See, e.g., Mu'min v. Virginia, 500 U.S. 415, 417 (1991) (noting that local media coverage of a murder was so pervasive that eight of the twelve jurors who condemned the defendant to death admitted pretrial exposure to publicity about the case).

${ }^{104}$ The potency of the death penalty in extracting guilty pleas from defendants is shown in North Carolina v. Alford, 400 U.S. 25 (1970). In that case, the Court recognized that it might be reasonable for a capital defendant who believes that he is innocent to plead guilty to avoid a possible death sentence. Id. at 37-38. The Court ruled that such "Alford pleas" can be accepted, over and against the defendant's claim of innocence, as long as the evidence provides a factual basis for the guilty plea. Id. at 38 n.10.

${ }^{105}$ It is not uncommon for state prosecutors to express displeasure with jury decisions giving life sentences to defendants convicted of capital crimes. These comments, as one would expect, range in intensity. Sometimes, prosecutors voice their disagreement with the sentence but respectfully defer to the sentencer's decision to grant leniency. See, e.g., Stephanie A. Stanley, Stogner Gets Life Sentence for Rape, Murder, Times-Picayune (New Orleans, St. Tammany Parish ed.), Oct. 20, 2001, at A1 ("'l'm 
Moreover, if there are enough cases in which they ask for death but do not get it, prosecutors face the risk that whatever "points" they may have obtained in the "toughness" category might have come at the expense of their reputation for professional competence or good stewardship of public resources. A "tough" but incompetent prosecutor, particularly one who routinely squanders taxpayer money through inordinately aggressive capital charging decisions, may ultimately be seen by his constituents as doing more harm than good.

Furthermore, high-profile defeats can harm a prosecutor's prospects for reelection or promotion. For example, the acquittals of O.J. Simpson and other celebrity murder defendants in Los Angeles are widely credited with how close then-District Attorney Gil Garcetti came to losing reelection in $1996 .{ }^{106}$ Garcetti's troubles continued, but, unfortunately for him, his luck did not: he was voted out of office in the next election. ${ }^{107}$

It makes perfect sense that voters will hold elected prosecutors accountable for achieving poor results in criminal cases. Prosecutors run for office based on competence as well as "toughness." For good or ill, incumbent prosecutors' win/loss ratios and deathsentence totals can serve as powerful evidence of professional

disappointed,' District Attorney Walter Reed said. 'I think he deserved the death penalty. But I accept the jury's verdict, and I respect it."'). Other prosecutors, however, are far less accommodating in their reaction. For example, Bob Macy, who was District Attorney for Oklahoma County at the time of the Oklahoma City bombing but left office before the state court prosecution of Terry Nichols, said that the jury's decision not to impose death "makes me sick." The Reaction, The Oklahoman, June 12,2004 , at $8 \mathrm{~A}$. Similarly, in a failed death penalty prosecution in Maryland, prosecutors said they were "very disappointed" that the defendant did not get death and considered it "frightening" that the defendant would not be executed. See Andrea F. Siegel, Williams Draws Life in Prison, Sun (Balt.), Aug. 22, 1998, at 1B. For similar reactions, see, e.g., Steve Kemme, Judge Spares Life of Killer, Cin. Enquirer, Oct. 10, 2000, at B1 ("Butler County Prosecutor Dan Gattermeyer, who had argued for the death penalty, expressed his deep disappointment with the sentence. 'I can't think of any case that is more appropriate for the death penalty,' he said."); Sylvia Martinez, Jurors Sentence Dallas Man to Life in Teacher's Slaying, Dallas Morning News, Nov. 8, 1992, at 37A ("We're extremely disappointed. We thought the death sentence was the appropriate sentence according to the evidence.").

${ }^{106}$ See Daniel C. Richman, Old Chief v. United States: Stipulating away Prosecutorial Accountability?, 83 Va. L. Rev. 939, 964 n.85 (1997).

${ }^{107}$ See Barbara Whitaker, Rocky Tenure Ends for Los Angeles Prosecutor, N.Y. Times, Nov. 10, 2000, at A18. 
competence. ${ }^{108}$ Prosecutors with weak records on either of these scores-which might be termed "leading prosecutorial indicators"-may find themselves vulnerable to defeat.

As a result, prosecutors have incentives to handle capital cases in ways that will minimize the risk of embarrassing defeats. They can do two things in particular to reduce the risk that the defendants they target for execution will receive life imprisonment instead of death. First, prosecutors can seek the death penalty only in cases involving the types of killings and defendants that juries are most likely to view as deserving of death. Second, once capital charges are filed, prosecutors can pour resources into presenting the strongest possible case for death. Both may seem like positive steps, but each has a less attractive underside when viewed in light of the politics of death.

As for who should and should not be charged with a capital offense or sentenced to death, it is in everyone's interest for those determinations to be made with great care and circumspection. Even so, however, to the extent prosecutors decide to seek death sentences based on predictions that jurors are likely to find certain classes of defendants or kinds of murders more deserving of death than others, one can expect to see a significant impact on the demographics of the population sent to death row. Perhaps the most obvious example is race.

The famous Baldus study at issue in McCleskey v. Kemp ${ }^{109}$ found significant racial disparities in Georgia capital cases, at both the charging and penalty stages. In Georgia, blacks who killed blacks had the lowest rate of death sentences, and blacks who killed whites had the highest. ${ }^{110}$ Additionally, defendants of any race who killed black victims had much lower chances of being sentenced to death than if their victims had been white.." Significantly, the

\footnotetext{
${ }^{108}$ See generally Erik Luna, System Failure, 42 Am. Crim. L. Rev. 1201, 1213 (2005) (discussing performance measures for prosecutors). Not surprisingly, incumbent prosecutors running for reelection or higher office routinely emphasize the number of prisoners they have put on death row. See supra note 96.

${ }^{109} 481$ U.S. 279 (1987).

${ }^{110}$ See id. at 286-87. See generally David C. Baldus et al., Equal Justice and the Death Penalty 149-69 (1990) (presenting results of Georgia study).

${ }^{111}$ See McCleskey, 481 U.S. at 286-87. This problem is not unique to Georgia. See Baldus et al., supra note 110, at 266 (finding "persuasive evidence" that "in many jurisdictions, defendants who killed white victims receive more punitive treatment than
} 
charging decisions by Georgia prosecutors reflected the same ordinal ranking of killers based on the race of the killers and victims, ${ }^{112}$ which suggests that prosecutors were applying selection criteria that they knew would appeal to prospective capital jurors. If so, the Baldus study serves as a chilling illustration of the adverse effects that can result when prosecutors decide whether or not to seek the death penalty by reference to how capital juries are likely to rule at the penalty phase.

More generally, if prosecutors endeavor to seek the death penalty against defendants whom juries are most likely to sentence to death, certain racial minorities and persons from other disadvantaged groups will be more likely to receive the ultimate sanction. This is because such groups tend to be underrepresented on capital juries. Through the process of "death qualification," the pool of potential jurors is carefully screened to exclude individuals who would be unable to set aside their personal views about the death penalty in deciding how to vote. ${ }^{113}$ Death qualification promotes the impartiality of capital juries, but does so at the expense of their representativeness. According to a study by Robert Fitzgerald and Phoebe Ellsworth, minorities (and especially blacks), women, and the poor, among other groups, are seriously underrepresented on death-qualified juries. ${ }^{114}$ This creates the risk that jurors in capital

those whose victims were black"). Nor is the problem limited to the charging and sentencing stages. See David Jacobs et al., Who Survives on Death Row? An Individual and Contextual Analysis, 72 Am. Soc. Rev. 610 (2007) (reporting post-sentencing empirical study finding that minority death-row inmates convicted of killing whites face higher execution probabilities than other capital offenders).

${ }_{112}$ See $M c$ Cleskey, 481 U.S. at 286-88. In McCleskey, the Supreme Court held that statistical analysis alone was insufficient to prove that the death penalty was applied in Georgia in an unconstitutional manner but, in doing so, implicitly accepted the Baldus study as reliable. See id. at 312-13.

${ }^{113}$ See Lockhart v. McCree, 476 U.S. 162, 167 (1986). Potential jurors who would not impose death even in cases where the law and evidence require that result are dismissed from service in capital cases. The same is true of individuals who would always vote for a death sentence, regardless of the law and evidence. Both categories of potential jurors lack the impartiality that the Sixth Amendment requires as a prerequisite to service on a capital jury. See generally id. at 173-83 (interpreting the constitutional requirement of an "impartial jury").

${ }^{114}$ See Robert Fitzgerald \& Phoebe C. Ellsworth, Due Process vs. Crime Control: Death Qualification and Jury Attitudes, 8 Law \& Hum. Behav. 31, 46 (1984). More controversially, Fitzgerald and Ellsworth contend that death qualification "specifically gerrymanders the jury against the large number of capital defendants who are black and poor by fencing out those who might bring to the deliberations the understanding 
cases will find it more difficult to show mercy to defendants from disadvantaged groups. ${ }^{115}$ Consequently, a prosecution-sorting mechanism tied to likely jury sentencing behavior can be expected to increase the likelihood that certain racial minorities and persons from other disadvantaged groups will be sentenced to death.

Similarly, vigorous presentation of the case for the government in capital cases takes on a different light given the politics of death. Ordinarily, vigorous prosecution is an unmitigated good because it helps ensure that the truth-seeking function of criminal trials will be fulfilled. In the context of capital sentencing hearings characterized by severe resource constraints on defense counsel, however, the effect is not nearly so salubrious. Many resource-constrained defense attorneys (particularly those who lack extensive experience in capital litigation) focus their efforts on the guilt phase at the expense of the penalty phase. ${ }^{116}$ With astonishing frequency, the result is weak or nonexistent mitigation cases. For example, in the trials of forty of the 131 prisoners Texas executed from January of 1995 to June of 2000 , defense lawyers presented "no evidence whatsoever or only one witness during the trial's sentencing

that arises from common experience." Id. The underrepresentation of blacks on capital juries is of concern for another reason as well: "Death sentences depend not only on the defendant's race, and not only on the victim's race, but on the juror's race as well. All else being equal, white jurors are more apt to vote for death than are black jurors." Theodore Eisenberg et al., Forecasting Life and Death: Juror Race, Religion, and Attitude Toward the Death Penalty, 30 J. Legal Stud. 277, 308 (2001).

${ }^{115}$ That this risk is real is shown by the fact that experienced capital defense attorneys believe it is essential at the penalty phase to humanize the client and educate the jury about the hardships and life experiences that predisposed the client to acts of violence. See Welsh S. White, A Deadly Dilemma: Choices by Attorneys Representing "Innocent" Capital Defendants, 102 Mich. L. Rev. 2001, 2024 n.129 (2004) (explaining that experienced capital defenders "have long recognized the importance of introducing mitigating evidence that will humanize the capital defendant, thereby leading the penalty jury to empathize with the defendant"). The classic exposition of this point is Gary Goodpaster, The Trial for Life: Effective Assistance of Counsel in Death Penalty Cases, 58 N.Y.U. L. Rev. 299, 320-39 (1983).

${ }^{116}$ In one of his last articles before his untimely recent death, Professor Welsh White reported the results of a series of interviews he had conducted with capital defense attorneys. See White, supra note 115 . He found that many defense attorneys who handle capital cases tend to overestimate the likelihood of obtaining favorable results for their clients at the guilt stage of capital trials. See id. at 2024-29. These defense attorneys, he reports, often make the mistake of focusing on the guilt stage to the exclusion of the penalty phase, leaving them grossly unprepared, when their clients are convicted, to demonstrate that death should not be imposed. See id. 
phase." 117 Given how unlikely resource-constrained capital defenders are to present serious cases in mitigation, the more effort and resources the prosecution invests at the sentencing stage, the less likely it will be that the jury's eventual life/death decision will accurately reflect whether or not the defendant truly deserves to die. The danger is that the decision will simply reflect the poor quality of representation the defendant received at the penalty phase from his court-appointed lawyer by virtue of the legislative funding "squeeze."118

$* * *$

In short, by virtue of the politics of death, prosecutors will concentrate their resources on a smaller number of capital cases and then devote the considerable energy and resources necessary to maximize the likelihood that those cases will end in death sentences. The prosecutors' extra effort in capital cases will be matched, on the defense side, by severe funding constraints that impede their ability to do the laborious factual investigation that is so vital to presenting a strong mitigation case at the penalty phase. A vigorous case for death, coupled with an inadequate effort to discover and prove grounds for leniency, will all too often leave death-qualified jurors with no basis on which to disagree with the prosecutor's judgment that the defendant should be put to death.

\section{Executive Clemency}

Like legislators and prosecutors, state governors and presidents are elected politicians. As such, these chief executives have incentives to take actions that will be popular with voters and avoid actions that will be unpopular with voters. On balance, this means that governors (particularly those who aspire to national office, as many no doubt do) and presidents will take steps to reduce the risk of being tagged by political opponents as "soft" on the death penalty. That risk can be minimized by supporting legislation promoting the death penalty and vetoing contrary legislation.

Then-Governor Bill Clinton understood this quite clearly. Determined not to repeat the mistake of the preceding Democratic

\footnotetext{
${ }^{117}$ Steve Mills et al., supra note 81.

${ }^{118}$ See Stephen B. Bright, Counsel for the Poor: The Death Sentence Not for the Worst Crime but for the Worst Lawyer, 103 Yale L.J. 1835, 1843-44 (1994).
} 
nominee for President, Massachusetts Governor Michael Dukakis, of opposing the death penalty, Clinton suspended campaigning on the eve of the 1992 New Hampshire Democratic primary to return to Arkansas to preside over an execution. The condemned man was "a brain-damaged, African-American" who had saved part of his last meal "thinking that he was going to come back and eat it after the execution." entered the White House. As president, he signed into law the Federal Death Penalty Act of $1994,{ }^{120}$ which expanded the death penalty to dozens of crimes, and the Antiterrorism and Effective Death Penalty Act of $1996,{ }^{121}$ a measure designed to promote the finality of state death sentences and expedite their execution. In 1996, the Clinton campaign understandably touted these measures in campaign ads during the President's successful reelection campaign. ${ }^{122}$

As former New York Governor Mario Cuomo learned the hard way in 1994, governors take action against the death penalty at their own peril. In that year, Cuomo's Republican challenger, George Pataki, made the death penalty an important issue in his campaign. ${ }^{123}$ Reminding voters that Cuomo had vetoed bills to reinstate capital punishment and had refused to extradite a prisoner named Thomas Grasso to Oklahoma to face capital charges, Pataki promised to bring back the death penalty and to return Grasso to Oklahoma if elected. Pataki was swept into office, and he kept both promises. ${ }^{124}$

${ }^{119}$ See Stephen B. Bright, The Politics of Capital Punishment: The Sacrifice of Fairness for Executions, in America's Experiment with Capital Punishment, supra note 8, at 127,130 .

${ }^{120}$ Pub. L. No. 103-322, §60002(a), 108 Stat. 1796, 1959-68 (1994) (codified as amended at 18 U.S.C. $\$ 3591$ (2000)).

${ }^{121}$ Pub. L. No. 104-132, 110 Stat. 1214 (1996) (codified as amended in scattered sections of the U.S. Code).

${ }^{122}$ See Bright, supra note 119, at 131.

${ }^{123}$ Id. For examples of other campaigns, federal and state, in which the death penalty played a key role in determining the ultimate winner, see id. at 129-32.

${ }^{124}$ Id. at 131 . Even after Pataki won reauthorization of the death penalty, capital punishment remains controversial in New York. After a recent state court decision finding procedural flaws in the state's new death penalty scheme, Pataki returned to the legislature for corrective legislation, but no such legislation has been passed yet. See Al Baker, Republicans Seek a Bipartisan Vote on a Bill to Reinstate the State's Death Penalty, N.Y. Times, Mar. 2, 2005, at B5. 
If a governor can be turned out of office based on opposition to the death penalty in New York, it can happen in any "death" state. After all, New York is a state in which opposition to the death penalty is widespread and deep. ${ }^{125}$ Nevertheless, even in New York, opposition to the death penalty has proven to be an issue that can spell defeat at the polls. ${ }^{126}$ This outcome, of course, is especially likely in the states that most actively enforce the death penalty; in those states, candidates who oppose the death penalty can be elected, if at all, only if they credibly promise to set aside their personal views and enforce their state's death penalty laws. ${ }^{127}$ Consequently, except in the staunchest abolitionist states where substantial majorities categorically oppose capital punishment, it is politically risky for governors or gubernatorial candidates to oppose (or allow themselves to be branded as opposing) the death penalty.

For legislators, the legislative and appropriations processes are their only opportunities for weighing in on the matter of the death penalty. This is not so for chief executives. Governors and presi-

${ }^{125}$ According to a 2005 New York Times poll:

Fifty-six percent of registered [New York] voters surveyed said they preferred either life in prison without parole or life in prison with the possibility of parole over the death penalty for people convicted of murder. Only 34 percent said they supported the death penalty, a significant drop from the 47 percent who supported it in 1994, when Mr. Pataki made instituting the death penalty a critical component of his successful drive to unseat Gov. Mario M. Cuomo.

Michael Slackman \& Marjorie Connelly, Pataki's Ratings Decline Sharply in Poll of State, N.Y. Times, Feb. 15, 2005, at A1.

${ }^{126}$ Even in neighboring New Jersey, where opposition to the death penalty was high enough to result in the abolition of capital punishment in 2007, Governor Corzine did not commute the sentences of the eight people on his state's death row until after the legislature abolished the death penalty. See Peters, supra note 52. Evidently, he was unwilling to make the case that the prisoners whom juries had sentenced to deathamong whom was the sex offender who raped and murdered Megan Kanka, see supra note 59-deserved leniency. Once the legislature had abolished the death penalty, of course, the governor could hardly be faulted for commuting the death sentences.

${ }^{127}$ An example is Virginia's governor, Democrat Timothy M. Kaine. During his campaign, Kaine was attacked for his stated moral opposition to the death penalty. The move backfired, and Kaine was ultimately elected because voters believed he would enforce the law despite his personal beliefs. See Michael D. Shear, Democrat Kaine Wins in Virginia, Wash. Post, Nov. 9, 2005, at A1 (explaining that Kaine responded to the attacks by pledging to "take an oath and enforce the death penalty" and citing surveys in which "voters said they believed Kaine's response and were angered by [his opponent]'s negative ads"). 
dents also have the executive power of granting clemency to individuals sentenced to death. ${ }^{128}$

As one might expect, the politics of death leave little room for clemency. Before the Furman Court politicized capital punishment, clemency was commonplace in capital cases, even in states known for their propensity to execute criminals. ${ }^{129}$ At a time when executions were becoming increasingly rare occurrences (as they were from the 1930s through the late $1960 \mathrm{~s}),{ }^{130}$ commuting death sentences was not the high-risk/low-gain proposition it is today. As importantly, perhaps, the capital-sentencing process was not shrouded in what has been aptly called an "aura of science" and courts were not viewed as the first (and last) line of defense against unjust executions. ${ }^{131}$ Knowledge that the judicial process is not infallible and acceptance of the view that the promotion of justice is as much a proper concern of political actors as of judges was quite conducive to the broad exercise of clemency powers, even in cases involving crimes as serious as murder.

Furman caused an about-face concerning how governors viewed clemency petitions from persons on death row. After the decision, there was a dramatic and sustained drop-off in exercises of clemency in capital cases. ${ }^{132}$ Evidently, courts (and especially the U.S. Supreme Court) came to be viewed as the guardians of justice in the administration of the death penalty. In that context, clemency seemed, at best, unnecessary. The courts, applying the new sentencing regimes enacted in response to Furman, would make sure that prisoners got leniency where leniency was deserved. There was a more cynical view, one in which frequent use of clemency powers would actually be inimical to the interests of justice. If the judicial process itself ensures that the death penalty will be visited only on the "worst" murderers, as many supporters of capital pun-

\footnotetext{
${ }^{128}$ See Herrera v. Collins, 506 U.S. 390, 411-14 (1993) (discussing the origins of clemency in the United States).

${ }^{129}$ See Austin Sarat \& Nasser Hussain, On Lawful Lawlessness: George Ryan, Executive Clemency, and the Rhetoric of Sparing Life, 56 Stan. L. Rev. 1307, 1310 (2004) (noting that prior to Furman "governors granted clemency in $20 \%$ to $25 \%$ of the death penalty cases they reviewed").

${ }^{130}$ See supra note 10.

${ }^{131}$ See Steiker \& Steiker, supra note 16 , at 360.

${ }^{132}$ See Hugo Adam Bedau, The Decline of Executive Clemency in Capital Cases, 18 N.Y.U. Rev. L. \& Soc. Change 255, 263 tbl.1 (1991).
} 
ishment think, then continued liberality in granting clemency would, almost by definition, spare from execution the very prisoners who are most deserving of it.

Today, clemency has virtually disappeared in capital cases. The 1990s saw no more than three death-row inmates receive clemency annually nationwide. ${ }^{133}$ That number is small enough on its own terms, but even smaller considering that, during the same period, there were close to three thousand death sentences handed down ${ }^{134}$ and sixty to eighty executions carried out nationally each year. ${ }^{135}$ In this respect, Florida is a bellwether of the national trend: "In Florida, one of the pillars of the 'death belt,' governors commuted $23 \%$ of death sentences between 1924 and 1966, yet no Florida death penalty sentences were commuted in the 1990s."136

Even more important than the lower rate of successful clemency applications is the changed conception of the power of clemency. Historically, clemency was understood principally in terms of morally laden concepts such as "mercy," "fairness," and "justice." Alexander Hamilton's defense of the Pardon Power in The Federalist Papers is illustrative. He argued that considerations of "[h]umanity and good policy" militate in favor of a power to grant clemency because "without an easy access to exceptions [from legally authorized punishment] in favour of unfortunate guilt, justice would wear a countenance too sanguinary and cruel.", ${ }^{137}$ In other words, the purpose of clemency was not simply to correct errors in the judicial process but rather to allow the chief executive to be a "dispenser of the mercy of the government." ${ }^{, 138}$ In order to serve its

\footnotetext{
${ }^{133}$ See Sarat \& Hussain, supra note 129 , at 1310.

${ }^{134}$ Each year during the 1990 s, an average of 291 death sentences were imposed nationwide, for a decade total of 2910 . See Tracy L. Snell \& Laura M. Maruschak, Capital Punishment, 2001, 2002 Bureau of Just. Stat. Bull. 13 tbl.1, http://www.ojp.usdoj.gov/bjs/pub/pdf/cp01.pdf.

${ }^{133}$ See Sarat \& Hussain, supra note 129 , at 1310.

${ }^{136} \mathrm{Id}$.

${ }^{137}$ The Federalist No. 74, at 385 (Alexander Hamilton) (Gideon ed., 2001).

${ }^{138}$ Id. Justice Kennedy echoed this traditional understanding in Dretke v. Haley, 541 U.S. 386 (2004):

The rigors of the penal system are thought to be mitigated to some degree by the discretion of those who enforce the law. The clemency power is designed to serve the same function. Among its benign if too-often ignored objects, the clemency power can correct injustices that the ordinary criminal process seems
} 
humanitarian purpose of "mitigation of the rigour of the law," Hamilton contended, the exercise of clemency powers should be "as little as possible fettered or embarrassed." 139 Those days, however, are long gone.

Ironically, given the natural tendency of institutional actors to aggrandize their powers and importance, contemporary state governors take an exceedingly narrow view of their clemency powers in capital cases. Governors invariably explain refusals to halt executions with statements that the prisoners' guilt had been conclusively proven and that the prisoners had had ample opportunity to seek relief in the courts. For example, as governor of Texas, George W. Bush said that he considered only two questions in weighing clemency petitions by inmates on death row: "Is there any doubt about this individual's guilt or innocence? And, have the courts had ample opportunity to review all the legal issues in this case?"140 That narrow formulation of clemency clearly suggests that contemporary chief executives increasingly view serious legal or factual error as the only proper basis for halting an execution.

The record of then-Governor Bush is unequivocal on this point. During his two terms as governor, Bush was presented with 154 clemency petitions from prisoners under sentence of death. Many of these cases rested largely or entirely on pleas for mercy. All of these petitions were denied. ${ }^{141}$

unable or unwilling to consider. These mechanisms hold out the promise that mercy is not foreign to our system. The law must serve the cause of justice. Id. at 399 (Kennedy, J., dissenting) (citation omitted).

${ }^{139}$ The Federalist No. 74 , supra note 137 , at 385 .

${ }^{140}$ See Sarat \& Hussain, supra note 129 , at 1309 . The point of view Bush expressed was not just the view of an especially conservative Republican governor. Democrat Bill Clinton took a similarly narrow view as governor of Arkansas. As he put it, "[t]he appeals process, although lengthy, provides many opportunities for the courts to review [death] sentences and that's where these decisions shouls' iu mavic." ici. at 1J1U. For a trenchant critique of such narrow conceptions of the clemency power, see Austin Sarat, Mercy on Trial: What It Means to Stop an Execution (2005).

${ }^{141}$ The most well-known example, which would later become an issue in Bush's first run for the White House, involved Karla Faye Tucker, a woman condemned to die for killing two people with a pickax. See Jim Yardley, Texas' Busy Death Chamber Helps Define Bush's Tenure, N.Y. Times, Jan. 7, 2000, at A1. Tucker admitted her guilt but asked to have her sentence reduced to life because, having undergone a conversion experience in prison (which included becoming a born-again Christian), she was no longer the violent person she once was. This conversion experience earned her clemency petition support from across the religious spectrum (including Pat Robertson 
Indeed, throughout his entire term of office, Bush only granted clemency to one death-row inmate: Henry Lee Lucas. Lucas was a notorious serial killer who admitted to killing up to six hundred people including an unidentified female hitchhiker referred to as "Orange Socks," a reference to the only items of clothing left on her brutalized, violated corpse. ${ }^{142}$ To his credit, Bush realized that even an individual as reprehensible as Lucas could deserve clemency. Bush successfully urged the Texas Board of Pardon and Paroles to recommend clemency on the basis of newly discovered evidence showing that Lucas could not possibly have killed "Orange Socks." ${ }^{143}$ In granting clemency to Lucas, Bush stressed his "special obligation to make sure the State of Texas never executes a person for a crime they may not have committed." ${ }^{144}$ Bush's record in Texas thus shows that, for the most part, clemency in capi-

and Pope John Paul II) as well as the international community, and it was one that weighed heavily on the mind of Bush, himself a born-again Christian. Id. Ultimately, however, Bush declined to intervene. Having "sought guidance through prayer" about Tucker's case, he concluded that "judgment about the heart and soul of an individual on death row are best left to a higher authority." Texas Governor Refuses to Intervene, N.Y. Times, Feb. 4, 1998, at A20 (quoting Bush's official statement). Bush's view that judgments about an inmate's "heart and soul" should be left to "higher authority" suggests that it is to God alone that pleas for mercy must be directed; a governor's only proper concern, when asked to grant clemency, is whether the condemned person is guilty and "ha[d] opportunity for access to the court and a thorough legal review." Id.

${ }^{142}$ See Allen R. Myerson, Citing Facts, Bush Spares Texas Inmate on Death Row, N.Y. Times, June 27, 1998, at A8.

${ }^{143}$ See Carol Marie Cropper, Commute Death Sentence of Multiple Killer, Texas Panel Says, N.Y. Times, June 26, 1998, at A10. One commentator provided the following account of Bush's behind-the-scenes role in orchestrating the favorable recommendation: "He intervened with the Texas pardons board before they had a chance to make a recommendation, and after his intervention, the board handed him the decision he wanted: a 17-1 vote for commutation of Lucas's death sentence." Helen Prejean, Death in Texas, 52 N.Y. Rev. Books 4, 4 (2005). In Texas, a favorable recommendation from the gubernatorially appointed board of pardons is a legal prerequisite to a pardon or commutation.

${ }^{14}$ See Myerson, supra note 142. Prosecutors had urged Bush to allow Lucas to be executed, despite the evidence of innocence, on the strength of Lucas's (false) confession. According to the state attorney general, the new evidence that Bush found to be so compelling did not warrant relief. The evidence did not prove that it was "impossible" that Lucas killed the victim; it merely showed that Lucas's involvement was "highly improbable." See Sam Howe Verhovek, Killer to Die for Sole Murder of His 10 that Is in Doubt, N.Y. Times, June 7, 1998, at A16. 
tal cases is reserved for executions that are wrongful, in the factual or legal sense, not executions that are wrong.

To be sure, some prisoners elsewhere have been spared execution purely on grounds of fairness or other moral considerations. A particularly interesting example involved Kevin Stanford, who was facing execution in Kentucky for a rape and murder ${ }^{145}$ On his last day in office, Governor Paul Patton reduced Stanford's sentence to life without parole because Stanford was a minor when he committed his crimes. ${ }^{146}$ The governor's action was remarkable because Stanford had lost in the Supreme Court on the claim that it was unconstitutional to execute juveniles. ${ }^{147}$ In keeping with the traditional understanding of clemency, the fact that the execution was legal did not necessarily make it right, and Patton's view was that his state "ought not be executing people who, legally, were children [when they committed their crimes]." ${ }^{148}$ It is thus possible, under the right set of conditions, for a death-row inmate to receive clemency on grounds other than legal or factual error.

Nevertheless, recent empirical analyses of capital clemency decisions have shown that such cases amount to the exceptions that prove the rule that clemency will not be granted except where necessary to correct serious factual or legal error in the judicial process. From 1977 to 2002, eighty percent of all clemency grants in capital cases nationwide were based on questions of legal or factual error. ${ }^{149}$ Only twenty percent of the clemency grants, issued by just

${ }^{145}$ See Jack Brammer, Patton Bids Office Farewell, Lexington Herald-Leader, Dec. 9,2003 , at B3.

${ }_{146} \mathrm{Id}$.

${ }^{147}$ See Stanford v. Kentucky, 492 U.S. 361 (1989), overruled by Roper v. Simmons, 543 U.S. 551 (2005).

${ }^{148}$ Brammer, supra note 145 . Even so, however, the governor was not immune to the pull of death's politics. By his own estimate, Patton had "more than 200" clemency petitions on his desk that "probably should have been granted," but he awarded relief only to Stanford because "doing that many [clemency grants] would have been an injustice." Courtney Kinney, Patton Cuts Last Day Short, Ky. Post, Dec. 9, 2003, at A11.

${ }^{149}$ See generally Elizabeth Rapaport, Straight Is the Gate: Capital Clemency in the United States from Gregg to Atkins, 33 N.M. L. Rev. 349, 353-55 \& n.38, 355 tbl.1 (2003). According to Professor Rapaport, seventy-two of the ninety clemency grants between 1976 and 2002 were issued to "prevent the loss of convictions and to conserve judicial resources," id. at 353, or "rectify[] legal system failures," id. at 355. 
six governors, were based on fairness and mercy grounds. ${ }^{150}$ Even that twenty percent figure substantially overstates the availability of clemency on grounds of simple fairness because roughly half of all clemency grants (and, in all likelihood, an even larger share of the grants of clemency on fairness grounds) come from states where few executions occur. ${ }^{151}$ Outside of these states, in the few cases where clemency is granted to a person on death row, there are almost always serious questions concerning either the legality of the death sentence or the prisoner's guilt.

In other words, across the nation, and especially in states that account for the bulk of executions in America, avoiding wrongful executions has come to be the purpose of clemency in capital cases. Factors related to mercy or fairness as opposed to innocence or the legality of the death sentence-that is to say, whether or not a defendant who was properly convicted of a capital offense should receive leniency based on factors particular to him-are largely deemed irrelevant to the clemency decision, particularly in the states that most actively enforce the death penalty. Thus, for defendants without strong claims of factual innocence or legal irregularity, clemency has become little more than an empty promise: if, when all is said and done, the judicial process has decreed death, then the prisoners' days are numbered.

The politics of death explain why clemency would come to be reserved largely for cases of serious factual or legal error. For a governor to grant clemency to a prisoner on death row would be a highly visible act, one sure to generate considerable media coverage and be noticed in future elections. It would also place the gov-

${ }^{150}$ See id. at $353-55 \&$ tbl.1. Although the "justice or mercy" category in Professor Rapaport's data set would suggest that more than half (forty-eight of the ninety) clemencies issued from 1976 to 2002 were based on fairness considerations, she notes that this category vastly overstates the true number of fairness-related grants. She explains that "[i]n thirty of the forty-eight cases [included in the 'justice and mercy' category], the governor or other clemency authority enacted the 'fail-safe' role, justifying grants of clemency as rectifying legal system failures." Id. at 355 . Because, in these thirty cases, clemency was not justified in terms of "ideals of justice and mercy not captured by legal justice," they are not properly counted as "fairness" grants. Id. Excluding these thirty cases leaves eighteen clemency grants out of a total of ninety, or twenty percent of all clemency grants from 1976 to 2002, that were actually issued for reasons of fairness and mercy. See also id. at 355 tbl.1.

${ }^{151}$ See Adam Gershowitz, The Diffusion of Responsibility in Capital Clemency, 17 J.L. \& Pol. 669, 686 (2001). 
ernor in conflict with powerful institutions of local government: the district attorney's office and the investigating police department. To grant clemency based on doubts concerning the defendant's guilt in the absence of compelling newly discovered evidence of innocence would tend to cast aspersions on the police for not building a stronger case and on the district attorney's office for going forward without better evidence. ${ }^{152}$ Likewise, for a governor to say that a death sentence imposed by jurors and upheld by the courts is so unjust as to warrant clemency would come perilously close to accusing the district attorney of having abused his discretion in pressing to carry out the death sentence. In both cases, a grant of clemency would expose the governor to the risk that political opponents could attack his commitment to enforcing the death penalty.

This is not to suggest that there are no circumstances in which governors might have incentives to grant clemency to an applicant without a claim of serious factual or legal error. To give an obvious example, for a governor who is leaving political life altogether, a bold act of clemency that would otherwise amount to political harikari could be a costless move that might draw praise as an act of statesmanship. This appears to have been the calculus behind the blanket commutations ordered in 2003 by outgoing Illinois Governor George Ryan. ${ }^{153}$

Similarly, political calculations might, with sufficient grounds for cover at least, give a governor interested in national office a reason

${ }^{152}$ This may explain why former Virginia Governor Mark Warner, in granting clemency in 2005 to a death-row inmate who claimed to be innocent, did not cite possible innocence as a reason for commuting the sentence. Instead, Warner pointed to the fact that a court clerk had illegally destroyed the evidence in the case, which made additional forensic testing impossible. See infra notes 154-156 and accompanying text. That tactic cleverly put the blame on the clerk, not police or prosecutors.

${ }^{153}$ In one of his last acts in office, Governor Ryan granted clemency to all 157 people on death row in his state. See Jeff Flock, 'Blanket Commutation' Empties Illinois Dcath Row, CNN.com, Jan. 13, 2003, http://www.cnn.com/2003/LAW/01/11/illinois.death.row/index.html. Unfortunately for Ryan, he was in a unique position to take such a risky step. After all, he was not running for reelection due to a scandal that led to his later indictment on federal corruption charges. With his political career coming to an end, Ryan had nothing to fear from the predictable political firestorm and, conceivably, benefited by receiving some favorable media coverage that diverted attention from his administration's legal and ethical problems. For a less cynical account of Ryan's commutations, see Rob Warden, Illinois Death Penalty Reform: How It Happened, What It Promises, 95 J. Crim. L. \& Criminology 381, 405-10 (2005). 
to grant an occasional clemency petition. As an example, consider the commutation that outgoing Virginia Governor Mark Warner granted in favor of a death-row inmate named Robin Lovitt. For Warner, then reputed to be an early favorite for the 2008 Democratic presidential nomination, it was advantageous to have an act of clemency on his record. If he had allowed Lovitt's execution, Warner would have been responsible for a chilling national milestonethe nation's 1000th execution since executions resumed in 1976and would have left office having allowed all twelve of the executions scheduled to take place during his tenure. ${ }^{154}$ This record could well have spelled trouble in a Democratic presidential primary because many liberals oppose capital punishment. ${ }^{155}$ Reducing Lovitt's sentence to life without parole allowed Warner to inoculate himself, to some degree, against possible attacks in Democratic primaries that his record on the death penalty was unacceptably conservative. At the same time, the fact that a state official had unlawfully destroyed the evidence that, according to Lovitt, would have exonerated him if tested for DNA gave Warner cover to grant clemency, as did the fact that Warner had refused to halt any of the preceding eleven executions over which he presided as governor. ${ }^{156}$ Thus, there are some limited situations in which governors might have incentives to grant clemency to death-row inmates on grounds other than factual or legal error.

Apart from these situations, the path of least resistance for a risk-averse governor is clear. Absent clear cases of factual or legal error, governors asked to grant clemency in a capital case should err on the side of allowing the judicial process to run its fateful course. That way, they avoid conflict with local law enforcement and crime victims. They also insulate themselves against charges that they are unwilling to enforce the death penalty. Therefore, with governors, as with legislators and prosecutors, the incentives are skewed in favor of death.

\footnotetext{
${ }^{154}$ See Frank Green, Governor Grants Clemency to Lovitt, Richmond TimesDispatch, Nov. 30, 2005, at A1.

${ }^{155}$ See Joseph Carroll, Who Supports the Death Penalty?, Gallup, Nov. 16, 2004, http:/www.gallup.com/poll/14050/Who-Supports-Death-Penalty.aspx (reporting that forty-six percent of self-identified liberals oppose the death penalty).

${ }^{156}$ See Green, supra note 154.
} 


\section{Judicial Incentives}

Judges are not political actors, yet they play an important role in the politics of death. This is especially true in the states because judges at all levels are popularly elected in the vast majority of states. ${ }^{157}$ The fact that they must stand for election and can be voted out of office gives them the same basic incentive as politicians and elected prosecutors not to stray too far from the outcomes that the public wants (or is perceived to want). It may be, as one leading commentator claims, that "even elected judges are much less politically accountable than legislators or elected prosecutors" due to the less contentious and less partisan nature of many judicial elections. ${ }^{158}$ Even so, it does not follow that state judges are free from the grip of the politics of death.

Lawyers and academics realize that crime is just one of any number of important areas over which judges exercise jurisdiction. Voters, however, are likely to give far greater weight to criminal cases. Ever fearful that they or their loved ones could become the latest crime statistic, voters perceive themselves as having a direct stake in criminal cases of a kind that they do not have in other judicial proceedings. ${ }^{159}$ If voters are victimized by criminals, they want assurance that the guilty parties will be punished accordingly. ${ }^{160}$ That can happen only if judges are willing to uphold guilty verdicts and impose tough sentences. Therefore, voters are likely

${ }^{157}$ Kathryn Abrams, Some Realism About Electoralism: Rethinking Judicial Campaign Finance, 72 S. Cal. L. Rev. 505, 512 (1999).

${ }^{158}$ Stuntz, supra note 62 , at 540.

${ }^{159}$ Recent polling data bear this out. For example, in 2007, Gallup conducted an opinion survey on public perceptions of crime. See Gallup's Pulse of Democracy: Crime (2007), http://www.gallup.com/poll/1603/Crime.aspx. Ninety-six percent of Americans listed crime as a serious problem, and most (fifty-seven percent) viewed crime as an "extremely serious" or "very serious" problem nationally. Id. Indeed, most people surveyed reported that they themselves worry about being the victim of serious crimes such as murder and rape. Fifty-two percent of respondents reported worrying, to some degree, that they might be murdered; the figure was forty-seven percent for rape or sexual assault. Id.

${ }^{160}$ A 2004 Gallup poll found that, even after decades of harsher sentencing laws and policies, Americans still want a tougher judicial system. Asked "if the U.S. criminal justice system is "too tough, not tough enough, or about right," a "firm majority $(65 \%)$ said that the criminal justice system is 'not tough enough' on crime." Heather Mason Kiefer, Public on Justice System: Fair, but Still Too Soft, Gallup, Feb. 3, 2004, http://www.gallup.com/poll/10474/Public-Justice-System-Fair-Still-Too-Soft.aspx. 
to pay close attention to how judges approach the criminal side of their dockets.

Without question, capital cases are among the most visible cases in criminal law. All the ingredients of high drama are present: a horrendous crime; sympathetic, grieving survivors pleading in interviews and in court for justice; and a high-stakes trial conducted with a life literally hanging in the balance. Voters tend to notice and remember these kinds of cases. More importantly, prosecutors and opponents of an incumbent judge can make voters take notice of and remember these kinds of cases through campaign "attack ads" if a judge votes the "wrong" way. These are the kinds of cases that can literally cause elected judges to be turned out of office.

The risk is real. From coast to coast, state judges have been voted out of office for not enforcing the death penalty with sufficient vigor. ${ }^{161}$ The risk that voting to overturn death sentences might have adverse consequences, incidentally, is not unique to state judges. Granted, federal judges are not politically accountable, in the sense that life tenure gives them the job security that their elected counterparts on the state judiciary lack. Nevertheless, the politics of death exert their pull on federal judges through the

${ }^{161}$ For an overview of elections in which state judges have been defeated based on votes against the death penalty, see Gerald F. Uelmen, Crocodiles in the Bathtub: Maintaining the Independence of State Supreme Courts in an Era of Judicial Politicization, 72 Notre Dame L. Rev. 1133, 1136-37 (1997). The most famous example involves three California Supreme Court justices, including Chief Justice Rose Bird, who were defeated in reelection campaigns in 1986 based on a record that was decidedly hostile to the death penalty. Republican California Governor George Deukmejian, citing what he viewed as their unwillingness to implement the death penalty, waged a high-profile campaign to have them turned out of office. See Scott D. Wiener, Note, Popular Justice: State Judicial Elections and Procedural Due Process, 31 Harv. C.R.-C.L. L. Rev. 187, 198-201 (1996). The result was a dramatic turnaround in the fate of death sentences in the high court: whereas the Bird court reversed eightythree percent of the death sentences it reviewed from 1979 to 1986, its successor court reversed only fifteen percent of the death sentences it reviewed from 1987 to 1995 . See Andrew Gelman et al., A Broken System: The Persistent Patterns of Reversals of Death Sentences in the United States, 1 J. Empirical Legal Stud. 209, 221-22 (2004). Mindful of how voters reacted in 1986 to justices with weak records of enforcing the death penalty, Democratic California Governor Gray Davis went to great lengths to screen his judicial nominees for willingncss to enforce dcath sentences. See Maura Dolan, Execution Issue Clouds Davis' Judge Selections, L.A. Times, Nov. 13, 1999, at A1. Several potential nominees later said they were "absolutely traumatized" by the grilling they received from Davis's staff on capital punishment and felt pressured to say "they thought the death penalty was the greatest thing since sliced bread." Id. 
process of judicial selection. A number of federal judicial nominees have run into problems in the Senate confirmation process for allegedly being "soft" on the death penalty. ${ }^{162}$ Thus, whether or not they have to stand for election in some way, the politics of death create incentives for judges to avoid casting votes that might be used as evidence of hostility to capital pumishment.

The effect of the politics of death can be seen in the sentencing practices of trial judges in capital cases. In most death penalty states, the jury makes the life/death decision, but nine states allow the trial judge to determine the sentence without a jury or, in jury cases, to override the sentence recommended by the jury; in eight of the nine "override" states, trial judges are elected. ${ }^{163}$ Capital overrides are quite common. According to one account, fully twenty percent of the death-row population in Florida got there because trial judges overrode jury recommendations of life imprisonment. ${ }^{164}$ Overrides may be less frequent in other states, but in all "override" states trial judges are significantly harsher sentencers in capital cases than even death-qualified juries. In such states, trial judges "(1) impose death sentences ... frequently (more often than juries) and (2) replace life sentences juries impose with death sentences... much more often than the reverse.,"165 The pattern and

${ }^{162}$ To give one fairly recent example, Missouri Supreme Court Justice Ronnie White, nominated by President Clinton for a seat on the U.S. District Court, was relentlessly (and successfully) opposed for alleged "pro-criminal" votes in capital cases. See David Stout, Senate Rejects Judge Chosen by President for U.S. Court, N.Y. Times, Oct. 6, 1999, at A18. The Missouri Sheriffs' Association and the Missouri Federation of Police Chiefs, among other members of the law enforcement community, lined up in opposition to the nomination. See Deirdre Shesgreen, Ashcroft Leads Attack as Senate Weighs White's Nomination, St. Louis Post-Dispatch, Oct. 5, 1999, at A1. Even though White had voted to uphold death sentences in forty-one of the fiftyfive capital appeals in which he had participated, he was opposed for being too "soft" on the death penalty. Id. The White nomination was hardly an isolated case. See Neil A. Lewis, G.O.P. to Challenge Judicial Nominees Who Oppose Death Penalty, N.Y. Times, Oct. 15, 1993, at A26.

${ }^{163}$ See Liebman, supra note 37 , at 2112 n.197.

${ }^{164}$ See Jason C. Tran, Death by Judicial Overkill: The Unconstitutionality of Overriding Jury Recommendations Against the Death Penalty, 30 Loy. L.A. L. Rev. 863, 874 (1997).

${ }^{165}$ See Liebman, supra note 37, at 2114. For example, Justice Stevens has noted that Alabama trial judges are ten times more likely to use their override power in capital cases to impose death where the jury recommended life than to spare the life of a defendant whom the jury condemned to death. See Harris v. Alabama, 513 U.S. 504, 521-22 (1995) (Stevens, J., dissenting) ("Alabama judges have vetoed only five jury 
frequency of judicial overrides suggest that elected trial judges err on the side of imposing death sentences.

Nevertheless, the situation is not necessarily as bleak as it might appear. In fact, even elected judges frequently do rule in favor of capital defendants, as a recent study of state capital sentences shows. ${ }^{166}$ This suggests that the incentives for judges to decide cases by reference to how their rulings might impact their future prospects for retention or promotion are countered, to some extent, by other factors. Any list of likely countervailing influences would include judicial integrity and the desire for respect in the professional community, not to mention the very pragmatic issue of avoiding potentially stigmatizing reversals by higher courts. ${ }^{167}$

Unfortunately, state courts do occasionally uphold death sentences when there is no reasonable basis in federal constitutional law for doing so. Williams $v$. Taylor, ${ }^{168}$ a case involving ineffective assistance of counsel at a capital sentencing hearing, is a case in point. The facts in Williams are chilling. The defendant had a history of violently assaulting elderly victims, and, in addition to killing an elderly man and burning down another's house (with the occupant inside), he beat an elderly woman so severely that she was left in a persistent vegetative state. ${ }^{169}$

The Virginia Supreme Court upheld the death sentence. Indeed, its decision in this regard was unanimous. ${ }^{170}$ The absence of recorded dissent suggests that the state court thought Williams was an easy case. If the case seemed easy, however, it must have been because of the deplorable nature of the defendant's crimes rather than the weakness of his arguments. After all, in the U.S. Supreme

recommendations of death, but they have condemned 47 defendants whom juries would have spared.").

${ }^{166}$ A study conducted by Professor Liebman and others found that sixty-eight of every one hundred capital sentences reviewed from 1973 to 1995 were overturned. See Liebman et al., supra note 64 , at 1852 . State courts accounted for forty-seven of the sixty-eight reversais. Id.

${ }^{167}$ See Stuntz, supra note 62 , at 540-42 (discussing these influences on appellate judges in criminal cases).

${ }^{168}$ Terry Williams v. Taylor, 529 U.S. $362,362(2000)$. There was a separate ruling in 2000 by the Supreme Court in another Virginia case involving a different petitioner named Williams. See Michael Williams v. Taylor, 529 U.S. 420 (2000). All citations in this Article to Williams $v$. Taylor refer to the case involving Terry Williams.

${ }^{169}$ Williams, 529 U.S. 362, at 368-69.

${ }^{170}$ Williams v. Warden of the Mecklenberg Corr. Ctr., 487 S.E.2d 194 (Va. 1997). 
Court, six Justices rejected the state court's decision and ruled that the sentence was constitutionally infirm. ${ }^{171}$

To be sure, the mere fact of disagreement between the federal and state courts on a question of federal law does not necessarily indicate that the state court's decision was unreasonable. The state court may simply have made a good-faith error about the meaning or application of federal law. Indeed, the state court may not have made an error at all. The decision of the state court may have been correct under the precedents in existence at the time but reversed based on unforeseeable later developments in federal law. ${ }^{172}$ Even apart from intervening changes in federal law, it is possible that, in cases of federal/state disagreement, it is the federal court that erred, not the state court. Justice Jackson's famous aphorism about the Supreme Court is surely applicable to the federal courts generally: "We are not final because we are infallible, but we are infallible only because we are final.",173

Nevertheless, the procedural posture in Williams shows that the case involved a serious error of judgment by the state court. Williams was a federal habeas corpus action subject to the stringent standards of the AEDPA. ${ }^{174}$ Consequently, the state court's decision could not be overturned based on a mere finding of legal error or changed legal standards. In the words of the statute, only "clearly established Federal law" could be applied, and even then the state court decision could not be set aside unless it was "con-

\footnotetext{
${ }^{171}$ See Williams, 529 U.S. at 391.

${ }^{172}$ The possibility of reversal based on later changes in federal law arises from the fact that decisions of the federal courts typically have retroactive effect. Full retroactivity of law-changing decisions is the rule in civil cases other than habeas corpus proceedings. See Harper v. Va. Dep't of Taxation, 509 U.S. 86, 97 (1993). It is also the rule in criminal cases that are pending on direct review at the time the law-changing decision is rendered. See Griffith v. Kentucky, 479 U.S. 314, 328 (1987). Habeas corpus is the one exceptional situation in which new rules of federal law will presumptively be denied retroactive effect. Under Teague $v$. Lane, 489 U.S. 288, 310 (1989), a prisoner is almost never entitled to the benefit of new rules of law handed down after his conviction became final. Even on habeas corpus review, however, new rules of federal law may be retroactively applicable in two exceptional, and rarely met, circumstances. See id. at 311-12 (ruling that retroactive application is proper on habeas corpus for new rulings that exempt conduct from criminal sanction or the death penalty or announce "watershed rules of criminal procedure" that significantly promote the accuracy of criminal trials).

${ }^{173}$ Brown v. Allen, 344 U.S. 433, 540 (1953) (Jackson, J., concurring).

${ }^{174}$ Williams, 529 U.S. at 391.
} 
trary to, or involved an unreasonable application of," clear federal law. ${ }^{175}$ The majority concluded that "both" prongs of the AEDPA standard were met. ${ }^{176}$ Thus, the reversal in Williams was far more than a mere finding of legal error; it was a finding that the state court acted unreasonably in upholding the prisoner's death sentence.

That finding, of course, might have been wrong. As one would expect, the dissenters argued precisely that. ${ }^{177}$ Interestingly enough, however, even they made no effort to defend the correctness of the state court's decision. Their argument was simply that the decision was not so erroneous as to constitute an "unreasonable application" of prior federal precedent within the meaning of the AEDPA. ${ }^{178}$ The majority's strong condemnation of the state court's decision, coupled witl the dissent's fairly tepid argument that habeas relief was improper, suggests that the state court's decision was indefensible as a matter of precedent.

To summarize, state courts do indeed reverse in capital cases. Indeed, given the potential risks involved in doing so, it is surprising just how frequently they overturn death sentences. Nevertheless, it remains the case that state courts do occasionally uphold death sentences in cases where, in the view of the federal courts at least, there was no reasonable basis in federal law for having done so.

${ }^{175} 28$ U.S.C. $\$ 2254(d)(1)(2000)$. The Court has explained the two prongs of the AEDPA standard as follows:

Under the "contrary to" clause, a federal habeas court may grant the writ if the state court arrives at a conclusion opposite to that reached by this Court on a question of law or if the state court decides a case differently than this Court has on a set of materially indistinguishable facts. Under the "unreasonable application" clause, a federal habeas court may grant the writ if the state court identifies the correct governing legal principle from this Court's decisions but unreasonably applies that principle to the facts of the prisoner's case.

Williams, 529 U.S. at 412-13.

${ }^{176}$ See Williams, 529 U.S. at 391 ("Williams is therefore entitled to relief if the Virginia Supreme Court's decision rejecting his ineffective-assistance claim was either 'contrary to, or involved an unreasonable application of,' [clearly] established law. It was both.”) (quoting 28 U.S.C. $\$ 2254$ (d)(1)); see generally id. at 391-99; id. at 413-16 (O'Connor, J., concurring).

${ }^{177}$ See id. at 417-18 (Rehnquist, C.J., concurring in part and dissenting in part).

${ }^{178}$ Id. 


\section{Summary: The "Politicized" Death Penalty}

The preceding survey of the basic incentives of the institutional players in the death penalty process reveals the kind of death penalty that the politics of death have produced in America. In each death penalty jurisdiction, there are, in effect, two different death penalty systems. One is the system that many supporters of capital punishment mistakenly believe we have; the other is the politicized death penalty that actually decides who lives and who dies.

The first system is one in which the ultimate sanction is reserved, in law and in fact, for the most heinous crimes and for the most deserving defendants. In such a system, death is imposed in a fair and outwardly rational manner based on a reliable, individualized determination that the sanction "fits" the defendant's crime. Even then, the system always takes seriously the possibility of leniencythat a defendant who committed a heinous crime may nevertheless be able to show that his life should be spared. This is an attractive system, and one would be hard-pressed to oppose such a system unless completely opposed to capital punishment on moral grounds. The problem is that this system exists only as an ideal.

The system that does exist is a politicized death penalty system in which the life-or-death decision is skewed in favor of death. Death is all too often used, not as the ultimate sanction, but rather as the ultimate slogan, a signal to voters of how "tough" politicians, prosecutors, and elected judges can be on crime. That "toughness," however, tends to be disproportionately directed at those who have had the hardest lives, such as individuals who suffer from mental illness or were subjected to horrific childhood abuse, and exercised in ways that allow race, poverty, and other arbitrary influences to factor into life/death decisions-influences to which capital juries will be much more likely to respond than more representative juries.

It is all too easy for prosecutors to make the case for death when the system makes it so difficult for capital defense lawyers to present effective cases on behalf of their clients. It strains credulity to think that overworked capital defenders embroiled in complex litigation at severe resource disadvantages will subject the prosecution's case to meaningful adversarial testing at either the guilt or penalty phase. Denied the resources necessary to do thorough fac- 
tual investigations, the defense will frequently go to trial ignorant of helpful evidence and fruitful lines of attack.

At the penalty phase, jurors are inundated with facts and arguments from the prosecution about the brutality of the crime and other reasons that the defendant deserves death. Needless to say, jurors need that information in order to decide the propriety of a death sentence. At the same time, however, jurors will not have a balanced picture unless they also get to hear facts and arguments from the defense about why the defendant should receive life instead of death. All too often, jurors never get to hear strong grounds for leniency, usually because the defendant's courtappointed attorney failed to unearth mitigating evidence. This would be bad enough in any event; it is even worse given that, by virtue of death qualification, capital jurors will already be predisposed to side with the prosecution and thus will need to be given compelling reasons to take seriously life imprisonment as an alternative to a death sentence. ${ }^{179}$ All this combines to make it much more likely that the end result of the trial process will be deathand death not, as Stephen Bright has written, for having committed the "worst crimes," but for having been assigned the "worst lawyers." 180

In the politicized death penalty system that we have, there is no guarantee that unjust or erroneous death sentences will be overturned. Except in cases of serious factual or legal error, there is little chance of being granted clemency, and the outcome of the judicial process will be decisive. By necessity, judges must think long and hard before setting aside a death sentence; otherwise, today's ruling may be tomorrow's election or confirmation controversy. This concern does not cause them to deny all capital defendants relief, but it does cause them to leave uncorrected some errors that are plainly contrary to existing precedents. As for the kinds of errors that, due to death's politics, may go uncorrected in the state

${ }^{179}$ As the Court noted in Witherspoon $v$. Illinois, death-qualified juries are "uncommonly willing to condemn a man to die." 391 U.S. 510, 521 (1968). Subsequent research has confirmed that assessment. See Brooke M. Butler \& Gary Moran, The Role of Death Qualification in Venirepersons' Evaluations of Aggravating and Mitigating Circumstances in Capital Trials, 26 Law \& Hum. Behav. 175, 182-83 (2002) (finding that death-qualified jurors give more weight to aggravation evidence and downplay mitigation evidence).

${ }^{180}$ See Bright, supra note 118 , at 1883. 
system, federal habeas provides an avenue of last resort, but only in rare, truly exceptional cases. ${ }^{181}$ At every step of the process, the politics of death have tilted the scales decidedly in favor of death.

\section{TOWARD A NEW "POLITICAL" APPROACH \\ TO DEATH PENALTY REFORM}

The following Sections canvass two different strategies that the Supreme Court has employed, at various times, in an effort to reform the death penalty. The first is referred to here as the "traditional" approach because it has been the primary approach the Court has taken since it subjected capital punishment to constitutional regulation in Furman v. Georgia. ${ }^{182}$ The contours of this approach are familiar. Less familiar, however, is the second, more aggressive approach that has emerged over the last few years. This approach might be described as "political," not because it reflects partisan considerations, but rather because it tends to counteract the politics of death. The second approach has the potential to succeed where its predecessor failed in accomplishing the basic aims of Furman and its progeny.

\section{A. The Traditional Approach}

In the first two decades after Furman, the Supreme Court's dominant strategy for death penalty reform was procedural in nature. Only rarely did the Court regulate the substance of the death penalty by exempting certain kinds of offenses or offenders from capital punishment. ${ }^{183}$ For the most part, the Court left such substantive matters to the political process. Instead, the Court focused heavily on process, seeking to mandate procedural safeguards that would bring reliability and rationality to the life/death decision and ensure that the death penalty would be restricted to the most deserving offenders. The result was a dizzying array of rules about how a constitutionally valid capital punishment scheme must be structured and implemented. These rules addressed a myriad of is-

\footnotetext{
${ }^{181}$ See 28 U.S.C. $\$ 2254(d)(1)$ (2000).

182408 U.S. 238 (1972).

${ }^{183}$ An example is Coker v. Georgia, 433 U.S. 584, 584 (1977), which ruled that death is a constitutionally excessive punishment for the crime of rape.
} 
sues such as the scope of voir dire,${ }^{184}$ capital jury disqualifications, ${ }^{185}$ the admissibility of certain kinds of evidence, ${ }^{186}$ and permissible argument at the penalty phase. ${ }^{187}$

Even under the weight of the mountain of precedent generated by the Supreme Court after Furman, the wheels of the "machinery of death," with which Justice Harry Blackmun famously gave up "tinker[ing]" at the end of his career, ${ }^{188}$ kept turning. The federal government is back into the death penalty "game" after decades on the sidelines. ${ }^{189}$ On average, someone has been put to death in the United States every ten days since the death penalty was reinstated in 1976 , for a total of more than one thousand executions. ${ }^{190}$ The last few years have seen a record-setting number of executions conducted in a single year-ninety-eight in 1999, the highest annual total since $1951^{191}$ - and, as of 2004 , there were more than three thousand people on death row nationwide. ${ }^{192}$ Thus, capital punishment, a practice that was in steady decline for almost fifty years prior to Furman, ${ }^{193}$ is now entrenched in American criminal practice.

${ }^{184}$ See, e.g., Turner v. Murray, 476 U.S. 28, 36-37 (1986) (addressing when capital defendants must be allowed to inquire into potential racial prejudice among veniremen).

${ }^{185}$ See, e.g., Lockhart v. McCree, 476 U.S. 162, 173 (1986) (upholding controversial practice of "death qualifying" jurors in capital cases even though death qualification produces more conviction-prone juries); Witherspoon v. Illinois, 391 U.S. 510, 521-23 (1968) (holding that persons with moral scruples against capital punishment cannot be excluded on partiality grounds unless they could not fairly decide guilt or innocence or would never impose death).

${ }^{186}$ See, e.g., Simmons v. South Carolina, 512 U.S. 154, 169 (1994) (holding that defendants are entitled to have jurors instructed when a sentence of life imprisonment would not result in eligibility for parole); Payne v. Tennessee, 501 U.S. 808, 827 (1991) (ruling that it is constitutional to admit "victim impact" evidence at the sentencing phase of capital trials); Lockett v. Ohio, 438 U.S. 586, 604-05 (1978) (holding that all potentially mitigating evidence must be admissible).

${ }^{187}$ See, e.g., Caldwell v. Mississippi, 472 U.S. 320, 336 (1985) (holding that it is unconstitutional for prosecutors to minimize the role of jurors in determining whether the defendant should live or die). For a comprehensive overview of the Court's major procedural mandates, see Steiker \& Steiker, supra note 16, at 371-402.

${ }_{188}$ Callins v. Collins, 510 U.S. 1141, 1145 (1994) (Blackmun, J., dissenting from denial of certiorari).

${ }_{189}^{189}$ See supra note 6 and accompanying text.

${ }^{190}$ See Goodman, supra note 27.

${ }^{191}$ See supra note 7 and accompanying text.

${ }^{192}$ See supra note 26.

${ }^{193}$ See supra note 10. 
This result was inevitable because an approach that regulates the structure and implementation of capital sentencing schemes is easily overcome by the politics of death. If new procedural mandates require amendments to capital sentencing statutes, prosecutors will certainly lobby for it. Prosecutors, after all, directly benefit from having the option to charge capital offenses (which makes it easier to extract guilty pleas) and from any changes that make the death penalty easier and cheaper to obtain (which makes their jobs easier and conserves their resources). When the utility of new legislation is brought to the attention of lawmakers, they can usually be counted on to supply the curative legislation. This is because legislators and prosecutors are "natural allies" in criminal law whose interests converge on being "tough" on crime and especially the crime of murder. ${ }^{194}$ The growing roster of capital crimes and aggravating factors in capital sentencing schemes, ${ }^{195}$ not to mention the swift reenactment of death penalty schemes after Furman, ${ }^{196}$ are examples of how willing legislators are to enact legislation necessary to satisfy new procedural mandates from the courts in the area of capital punishment.

Many procedural mandates, however, do not require new legislation and can readily be satisfied in new sentencing hearings. Examples include instructional error and improper exclusion of defense evidence at the sentencing phase. Reversals on procedural grounds such as these can be cured simply by retrying the sentencing phase. In these situations, prosecutors may have strong incentives not to acquiesce in their losses on appeal and to seek reinstatement of the death sentence, having committed themselves at the chargeselection stage to litigate for however long it might take to obtain a death sentence. Often, new sentencing hearings will produce the same outcome: a sentence of death. ${ }^{197}$

\footnotetext{
${ }^{194}$ Stuntz, supra note 62 , at 534 .

${ }^{195}$ See supra Subsection II.A.1.

${ }^{196}$ See supra note 18.

${ }^{197}$ This is exactly what happened in the prosecution of Walter Mickens, Jr., in the wake of Simmons v. South Carolina, 512 U.S. 154 (1994). Simmons gave defendants the right to have jurors at sentencing informed of the availability of life without possibility of parole as an alternative to a death sentence. Id. at 156 (plurality opinion). Because Mickens was denied that right, the Virginia Supreme Court vacated his death sentence. See Mickens v. Commonwealth, 457 S.E.2d 9, 10 (Va. 1995). The prosecutor did not give up but again sought a death sentence; the second sentencing hearing, like the first, ended in a sentence
} 
The most that a dominantly procedural approach can hope for in terms of limiting capital punishment, then, is to make capital sentencing so resource intensive as to give prosecutors incentives, at the margin, not to seek capital charges. This, in fact, is precisely what has happened: prosecutors concentrate their resources on a smaller number of capital cases, and a significant reason for doing so is to avoid the high costs of obtaining and carrying out death sentences. ${ }^{198}$ Nevertheless, cost-driven decisions not to seek death are not properly counted as successes of the Furman regime. After all, it is possible that, but for the Court's intervention, the politics of death would not have arisen and capital punishment would have continued to fade away. ${ }^{199}$

More fundamentally, reducing the number of executions was not the goal of Furman. Indeed, the fact that the death penalty was so rarely imposed was one reason the Court struck it down. The following reasoning by Justice Potter Stewart, a member of the Furman majority, illustrates the point: "[O]f all the people convicted of rapes and murders in 1967 and 1968, many just as reprehensible as these, the petitioners are among a capriciously selected random handful upon whom the sentence of death has in fact been imposed." 200 As the quote suggests, the goal was to bring fairness and rationality to the capital sentencing process. Thus, the fact that the death penalty is being used less today than it might otherwise

of death. See Beverly N. Williams, Convicted Killer Receives Death Penalty, Daily Press (Newport News, Va.), Mar. 30, 1996, at C1. After being denied judicial relief and clemency, Mickens was executed in 2002. See Man Executed for Killing 17-year-old, United Press Int'l, June 12, 2002, http://www.upi.com/NewsTrack/Top_News/2002/06/12/ man_executed_for_killing_17yearold/2808/.

${ }^{198}$ See supra Subsection II.B.1.a (discussing resource concentration in post-Furman capital cases). It is difficult to find reliable studies of the costs of obtaining and carrying out death sentences. The available cost estimates are advocacy driven, with opponents of capital punishment reporting high costs and supporters minimizing the costs. Nevertheless, a recent article by an apparent death penalty supporter claims that the "average cost per execution in the United States ranges from $\$ 2$ million to $\$ 3$ mil. lion," with extraordinary cases potentially costing even more. See David A. Wallace, Dead Men Walking-An Abuse of Executive Clemency Power in Illinois, 29 U. Dayton L. Rev. 379, 396 (2004).

${ }^{199}$ See supra notes 5-7 and accompanying text.

${ }^{200}$ Furman, 408 U.S. at 309-10 (Stewart, J., concurring) (footnote omitted). 
be, even if true, may simply mean that the death penalty today remains as arbitrary as it was before Furman. ${ }^{201}$

\section{B. The Emerging "Political" Approach}

Over the last decade, as the death penalty has risen to new heights in America, the Supreme Court has developed what amounts to a very different approach to reforming the death penalty. Instead of continuing to rely mainly on procedural reforms that are easily vitiated by the politics of death, the Court has recently adopted a new approach to bringing rationality and fairness to the capital sentencing process-an approach that takes direct aim at the politics of death. There are two basic elements to the new approach. The first is much more aggressive use of the Eighth Amendment to carve out substantive exceptions to the death penalty. The second is heightened emphasis on the quality of representation defendants receive in capital cases, an issue of vital importance to the effort to rationalize the imposition of death.

Taken together, these developments suggest that the Supreme Court finally understands the deleterious effect of the politics of death on efforts to reform the institution of capital punishment. Rather than give up on the prospect of reforming the death penalty through constitutional adjudication, as critics on the left and right have urged, ${ }^{202}$ the Court seems determined to use the Constitution to counteract the politics of death and promote fairer, more reliable determinations of who deserves to die. More than simply a stunning new development in constitutional law, it represents a Uturn, with the Court now pursuing reformist strategies that, until

${ }^{201}$ The Steiker and Steiker hypothesis is exactly that: measured in terms of its animating goals, the Furman regime has been a monumental failure. See generally Steiker \& Steiker, supra note 16, at 360 ("We conclude, with gloomy irony, that the Supreme Court's Eighth Amendment jurisprudence, originally promoted by selfconsciously abolitionist litigators and advanced by reformist members of the Court, not only has failed to meet its purported goal of rationalizing the imposition of the death penalty, but also may have helped to stabilize and entrench the practice of capital punishment in the United States.").

${ }^{202}$ Compare, e.g., Callins v. Collins, 510 U.S. 1141, 1145 (1994) (Blackmun, J., dissenting from denial of certiorari) (rejecting the Court's death penalty jurisprudence as unworkable and endorsing the view that the death penalty is per se unconstitutional), with Walton v. Arizona, 497 U.S. 639, 656-73 (1990) (Scalia, J., concurring in part and concurring in the judgment) (rejecting the Court's death penalty jurisprudence as unworkable and urging greater flexibility for states in capital sentencing). 
recently, were "not merely roads not taken but roads deliberately forsaken" in the post-Furman era. ${ }^{203}$

\section{Expanded Substantive Regulation}

The most natural place for the Court to turn for a new political approach to capital punishment is the Eighth Amendment. If the problem with procedural reforms of the type mandated in Furman and its progeny is that the politics of death will cause substantive law to be changed in ways that undermine those reforms, an obvious solution is to regulate the substance of death eligibility. After all, rulings that categorically exempt certain crimes or classes of offenders from capital punishment will be more impervious to subversion by the political process than purely procedural mandates engrafted upon unregulated substantive law. ${ }^{204}$ The Eighth Amendment's prohibition of "cruel and unusual punishment" was a logical place for reform-minded Justices to ground decisions creating exemptions from capital punishment because of its dynamic nature. The amendment has been read as allowing courts to strike down punishments that, in their independent judgment, violate the

${ }^{203}$ Steiker \& Steiker, supra note 16 , at 414 . Back in 1995 , Professors Steiker and Steiker lamented the fact that the Supreme Court had not pursued a variety of alternative strategies for reforming capital punishment. See id. at 414-26. Among these "roads not taken," as they put it, were the two avenues discussed below: greater substantive regulation of the death penalty and greater emphasis on issues of representational quality. See id. at 415-21 (substantive regulation); id. at 421-23 (quality of counsel). At that time, there was not even a hint that the Court would reverse course, and, in any event, Professors Steiker and Steiker gloomily questioned whether "these (or any other) strategies could rationalize to an acceptable degree the administration of capital punishment in America." Id. at 360. The goal here is to demonstrate that the Court has indeed reversed course and to describe the key elements of the new approach-which has considerable promise precisely because it, unlike the roads previously taken, is tailored to counteract some of the more insidious effects of the politics of death.

${ }^{204}$ For example, short of a constitutional amendment, there is no evident way for legislatures to get around the ruling in Coker v. Georgia that death is a constitutionally impermissible penalty for raping an adult. 433 U.S. 584, 592 (1977). To the contrary, even substantive constitutional regulation can at times be evaded by the political process. An example is Atkins $v$. Virginia, where the Court exempted the mentally retarded from capital punishment. 536 U.S. 304, 321 (2002). Because the proper definition of mental retardation is neither self-evident nor supplied by Atkins, legislatures can undermine the Atkins mandate by defining mental retardation narrowly. 
"evolving standards of decency that mark the progress of a maturing society.",205

One of the most striking developments in current death penalty law has been the Supreme Court's more aggressive use of the Eighth Amendment's proportionality requirement. In the twenty years following reinstatement of the death penalty in 1976, the Court was quite restrained in carving out exceptions to capital punishment. The Court did so infrequently, only in instances where there were strong objective indicia (usually from legislative enactments nationwide) that particular offenses or offenders did not merit the ultimate sanction. For example, by the time Coker $v$. Georgia $^{206}$ was decided, Georgia was the only state that classified rape as a capital offense, and even then Georgia juries usually did not sentence rapists to death. ${ }^{207}$ To be sure, the Coker majority did assert the right to exercise its own independent judgment about when death is a constitutionally disproportionate sanction. In practice, however, the Court took the lead on that question from legislatures and juries, both in Coker and other capital proportionality decisions, and created exemptions from the death penalty only in contexts in which most states had already done so. ${ }^{208}$

${ }^{205}$ Trop v. Dulles, 356 U.S. 86, 100-01 (1958). The emphasis on independent judgment is key because it loosens the Eighth Amendment from its moorings in traditional Anglo-American criminal practice, allowing even commonly imposed punishments authorized by many states to be struck down as "cruel and unusual."

${ }^{206} 433$ U.S. 584 (1977).

${ }^{207}$ Id. at 595-97. The death penalty for rape was applied in a racist manner in Georgia in that death "was used almost exclusively to punish black men who had been convicted of raping white women." See Samuel R. Gross, The Risks of Death: Why Erroneous Convictions Are Common in Capital Cases, 44 Buff. L. Rev. 469, 479 n.46 (1996).

${ }^{2008}$ See, e.g., Roper v. Simmons, 543 U.S. 551, 609 (2005) (Scalia, J., dissenting) ("Our previous cases have required overwhelming opposition to a challenged practice, generally over a long period of time."). Another pertinent example of the restrained approach the Court has taken in the capital proportionality context is Enmund v. Florida, 458 U.S. 782 (1982). In that case, the Court ruled that death is "cruel and unusual" punishment for persons who, without intent to kill, aided and abetted a felony during which someone else commits a killing and who had no role in the killing. Id. at 797. The opinion contained the usual disclaimer about exercising independent judgment on the proportionality determination, id., but the driving force for the outcome clearly lay elsewhere: "only a small minority of jurisdictions," said the Court, authorized death for such persons, and the evidence was "overwhelming" that juries only rarely imposed death on such persons absent aggravating factors. Id. at 792, 794. 
The great deference the Supreme Court has shown in this area has been thrown to the winds in its most recent proportionality decisions. In exempting the mentally retarded $\mathrm{d}^{209}$ and juveniles ${ }^{210}$ from the death penalty, the Court has gone far beyond its prior practice of using the proportionality standard to bring outlier states in line with prevailing value judgments enshrined in the statutes of most states. In both contexts, the states were closely divided, with most states having either rejected or not endorsed the categorical exemptions the Court read into the Eighth Amendment. ${ }^{211}$ Where it had previously found an insufficient basis for exempting juveniles and the mentally retarded from the death penalty, the Court dramatically reversed course in Roper v. Simmons and Atkins v. Virginia, respectively. ${ }^{212}$

In these cases, for the first time, it truly was independent judicial judgment that drove the proportionality analysis. In the Court's view, there were strong moral reasons for leniency for juvenile and mentally retarded offenders, and no valid penological reason for executing those offenders. ${ }^{213}$ Evidently, the fact that the laws of most death penalty states did not recognize those reasons as valid, which historically would have led the Court to leave the issue to the political process, became grounds for constitutionalizing the issue and placing it beyond the reach of politics.

\footnotetext{
${ }^{209}$ Atkins v. Virginia, 536 U.S. 304, 321 (2002).

${ }^{210}$ Roper, 543 U.S. at 568.

${ }^{211}$ At the time of Roper, more states than not allowed the execution of juveniles: whereas eighteen death penalty states had exempted juveniles aged sixteen and over, twenty had reached the opposition conclusion. Id. at 564. The numerical breakdown was the same in Atkins: eighteen death penalty states provided exemptions of some kind for mentally retarded persons charged with capital offenses, as compared to twenty states that did not. 536 U.S. at 321-22 (Rehnquist, C.J., dissenting). To be fair, the head count tilts in the Court's favor in both cases if the twelve states that have completely abolished capital punishment are taken into account. Even if abolitionist states are counted, however, there would still not be the high level of consensus among the states that was typically required before a punishment could be invalidated as contrary to evolving standards of decency. See, e.g., Coker, 433 U.S. at 595-96 (noting that all but one state agreed that death was not a proper penalty for rape).

${ }^{12}$ See Roper, 543 U.S. at 574 (overruling Stanford v. Kentucky, 492 U.S. 361 (1989)); Atkins, 536 U.S. at 321 (overruling Penry v. Lynaugh, 492 U.S. 302 (1989)).

${ }^{213}$ The Court argued in both cases that neither retribution nor deterrence justified the death penalty for crimes by juvenile or mentally retarded offenders and that, from a moral perspective, such offenders were less culpable than other offenders. See Roper, 543 U.S. at 564-72; Atkins, 536 U.S. at 318-20.
} 
Though inexplicable in terms of prior Eighth Amendment practice, Roper and Atkins are readily explained as an effort by the Supreme Court to counteract the politics of death. With the visibility and popularity of the death penalty since Furman $v$. Georgia, there is little gain, and much risk, in politicians championing measures exempting certain classes of offenders from the death penalty. This will hold true even if a majority of voters would actually support exemptions if given the opportunity. Proposals to exempt categories of offenders from the death penalty are very likely to prompt opposition from prosecutors and police groups. These are not only very powerful interest groups in the legislative process, but effective at election time in helping voters see who is, and who is not, "tough" on crime. In all likelihood, risk-averse legislators will propose categorical exemptions only if there is likely to be overwhelming public support for them. If the political process is so firmly in the grip of the politics of death that legislative enactments cannot be counted upon to reflect community mores concerning the propriety of capital punishment in particular contexts, then the search for "evolving standards of decency" cannot be limited to a legislative head count.

One obvious place to look for community sentiment about the death penalty is the sentencing decisions of capital juries. The Court has long considered those decisions as an indicator of community views about when death is an inappropriate sanction, ${ }^{214}$ which is sensible enough because the jury's role in criminal cases is to represent the community from which it is drawn. ${ }^{215}$ Nonetheless, for a number of reasons-not the least of which is the practice of death-qualifying jurors in capital cases-the jurors seated in death penalty cases will tend to be far more supportive of the death penalty, and far less likely to see grounds for leniency, than the community at large. ${ }^{216}$ To the extent the Court doubts that legislatures and capital juries will reliably reflect the views of the larger community about whether or not certain offenders should be exempt

\footnotetext{
${ }^{214}$ See, e.g., Coker, 433 U.S. at 596-97.

${ }^{215}$ See, e.g., Taylor v. Louisiana, 419 U.S. 522, 530 (1972) ("[T]he purpose of a jury is ... to make available the commonsense judgment of the community as a hedge against the overzealous or mistaken prosecutor and in preference to the professional or perhaps overconditioned or biased response of a judge.").

${ }^{216}$ See supra note 179 .
} 
from the death penalty, it makes sense to consider polling data and other indicia of community mores. ${ }^{217}$

Similarly, if the proverbial deck is so heavily stacked against death penalty reforms that even popular reforms may be defeated in the political process, then a natural response would be to lower the Eighth Amendment threshold. Except in the most extreme cases, a high degree of consensus as to the impermissibility of the death penalty in particular contexts will be unlikely to emerge. The political process will tend to leave those sorts of questions to prosecutors and juries to decide in the contexts of individual prosecutions, particularly in jurisdictions where support for capital punishment is strong. ${ }^{218}$ Consequently, it is of enormous significance in the Eighth Amendment search for evolving standards of decency that a substantial number of death penalty states have enacted categorical exemptions for certain types of offenders. Significant minority support among legislatures for categorical exemptions may suggest that, but for the distorting effects of the politics of death, more death-penalty states might have followed suit, resulting in a true numerical "consensus" against the death penalty in those situations.

${ }^{217}$ See Atkins, 536 U.S. at 316 n.21 (citing, among other things, polling data as "lend[ing] further support to our conclusion that there is a consensus [against executing the mentally retarded] among those who have addressed the issue"). Although imperfect, polls have the advantage of asking respondents to make a decision in the abstract, without regard to arbitrary factors, such as race, that might creep into a jury's life-or-death decision or to the sheer brutality of a particular crime. Much harder to justify is the Court's reliance, in both Atkins and Roper, on foreign law or, more precisely, the law of other Western industrialized democracies. See, e.g., id.; Roper, 543 U.S. at 575-78. At least polling data is aimed at showing what the American people think about particular issues of public policy; needless to say, foreign law can shed no light on that question.

${ }^{218}$ Mental retardation is a case in point. As the Atkins majority noted, "polling data shows a widespread consensus among Americans, even those who support the death penalty, that executing the mentally retarded is wrong." 536 U.S. at $316 \mathrm{n} .21$. Nevertheless, slightly more than half of the "death" states failed to exempt the mentally retarded from the death penalty. See supra note 211 . The disparity between public sentiment and legislative enactments is even more striking with respect to mental illness. According to a 2002 Gallup poll, seventy-five percent of Americans oppose execution of the mentally ill, yet "Connecticut is the only state that has legislatively proscribed imposing the death penalty on mentally ill defendants." Helen Shin, Note, Is the Death of the Death Penalty Near? The Impact of Atkins and Roper on the Future of Capital Punishment for Mentally Ill Defendants, 76 Fordham L. Rev. 465, 494 (2007); see also id. at 504 (citing Gallup poll results). 
None of this, of course, is to suggest that Atkins and Roper were correctly decided. It is to suggest merely that something very different has crept into recent proportionality cases. At the very time that the Supreme Court has made it all but impossible to overturn prison sentences on proportionality grounds, ${ }^{219}$ the Court has significantly relaxed long-standing standards for mounting successful proportionality challenges to capital punishment. The usual, "death-is-different" approach to capital punishment explains why capital cases are assessed under a more stringent proportionality standard than noncapital cases. It cannot, however, explain why a Court that is otherwise so committed to the cause of federalism would ratchet up long-standing capital proportionality principles in a way that makes it considerably easier to overturn state legislation authorizing execution of juveniles or the mentally retarded. The explanation for this dramatic new development seems to be that a majority of the Court now recognizes that the politics of death have stymied ongoing efforts since Furman to rectify injustices in the administration of the death penalty. Quite naturally, this recognition has led to substantially more aggressive use of capital proportionality review to impose substantive limitations on the death penalty.

\section{Counteracting the Funding "Squeeze"}

Substantive proportionality review is not the only area in which the Supreme Court has recently employed more intensified review based on an appreciation of the politics of death. The Court has also revisited the long-standing rule that the Sixth and Fourteenth Amendments give defendants the right to the effective assistance of counsel. ${ }^{220}$ Not coincidentally, every one of the cases involved

\footnotetext{
${ }^{219}$ See Ewing v. California, 538 U.S. 11, 23-24 (2003) (endorsing a stringent gross disproportionality standard and upholding California's controversial three strikes law, which authorizes life imprisonment for repeat offenders even for trivial property crimes). As I have discussed elsewhere, Ewing and other cases show that, "[f]or all practical purposes, the Court is out of the business of using the Constitution to regulate the proportionality of prison sentences other than life imprisonment." Stephen F. Smith, Proportionality and Federalization, 91 Va. L. Rev. 879, 892 (2005).

${ }^{220}$ See generally Strickland v. Washington, 466 U.S. 668 (1984) (exploring the nature of the right to effective assistance and enunciating standards for evaluating claims of ineffective assistance). The notion that ineffective representation violates due process predated Strickland by half a century. See Powell v. Alabama, 287 U.S. 45, 71 (1932).
} 
the death penalty. The result was that the Court reinterpreted the settled standard governing ineffective assistance claims. The new approach made it considerably easier for death-row inmates to challenge their sentences based on errors by their attorneys. As demonstrated below, the Court's newfound interest in the quality of defense representation in capital cases reflects a keen appreciation of how the politics of death have operated to defeat the Court's goal of having an accurate and reliable determination of whether or not death is deserved in every case.

\section{a. The Traditional Ineffectiveness Standard}

Zealous, competent defense representation is the very linchpin that holds together the Furman scheme for bringing rationality and fairness to the administration of the death penalty. If prosecutors do their jobs right, they will seek death only in the kinds of cases that jurors would very likely view as sufficiently egregious to warrant society's ultimate sanction. Once capital charges are filed, prosecutors have every incentive to avoid embarrassing defeats, which means they will vigorously present the case for death. The audience for that case-generally speaking, the same jury that convicted the accused of capital murder-will, by its very nature, be predisposed to agree with the prosecution. After all, deathqualified jurors are more willing to impose death, and more conservative on law-and-order issues generally, than the larger community. ${ }^{221}$

To say the least, then, defense attorneys face an uphill battle at the penalty phase of a capital case. Unless they offer the sentencer compelling reasons to show leniency in spite of the brutality of the crime, the penalty phase is all too likely to end in a verdict of death. To have any hope of convincing the sentencer to choose life over death requires, first and foremost, diligent investigation into the facts. Maybe the defendant was not as culpable as he appears for prior crimes charged as aggravating factors. Maybe there are factors lurking in the defendant's life history that make him legally

\footnotetext{
${ }^{221}$ See supra note 179 . In the comparatively rare cases where judges make the lifeor-death decisions, trial judges often have strong incentives to err on the side of denying leniency. See supra note 161.
} 
ineligible for execution, such as mental retardation, ${ }^{222}$ or that constitute strong grounds for leniency, such as an extremely abusive childhood. The sentencer will never know, however, unless capital defenders fully inform themselves as to all potential grounds for leniency and exercise reasonable professional judgment and skill in evaluating the facts and presenting the case against a death sentence. The defense attorneys' performance, quite literally, is a matter of life and death.

The issue of when attorney errors deprive defendants of a fair trial came before the Supreme Court in Strickland v. Washington. ${ }^{223}$ The majority, led by Justice Sandra Day O'Connor, adopted a twopart test governing claims of ineffective assistance of counsel. To obtain reversal, defendants must prove defective performance by their attorneys and prejudicial effect on the outcome of their cases. $^{224}$ This standard governed in capital trials and other criminal trials alike; the majority declined to distinguish capital cases from "ordinary" trials.

To his credit, Justice Thurgood Marshall saw that there was a major reason to distinguish capital trials from noncapital trials: the Furman regime. He wrote that " [r]eliability' in the imposition of the death sentence can be approximated only if the sentencer is fully informed of 'all possible relevant information about the individual defendant whose fate it must determine." ${ }^{226}$ Justice Marshall

${ }^{222}$ See Atkins, 536 U.S. at 321.

${ }^{223} 466$ U.S. 668 (1984).

${ }^{224}$ Id. at $690-94$. The performance prong of Strickland requires the defendant to prove that, based on what the attorney knew or should have known at the time, the attorney's handling of the case was "outside the wide range of professionally competent assistance." Id. at 690 . The prejudice prong requires defendants to demonstrate "a reasonable probability that, but for counsel's unprofessional errors, the result of the proceeding would have been different." Id. at 694 .

${ }^{225}$ Strickland, 466 U.S. at 687.

${ }^{226}$ Id. at 715 (Marshall, J., dissenting) (quoting Jurek v. Texas, 428 U.S. 262, 276 (1976)). Justice Brennan also saw the connection Justice Marshall highlighted. See id. at 706 (Brennan, J., concurring in part and dissenting in part) ("Of course, ' $[t]$ he right to present, and to have the sentencer consider, any and all mitigating evidence means little if defense counsel fails to look for mitigating evidence or fails to present a case in mitigation at the capital sentencing hearing." (quoting Helen Gredd, Comment, Washington v. Strickland: Defining Effective Assistance of Counsel at Capital Sentencing, 83 Colum. L. Rev. 1544, 1549 (1983)). The difference between the two was that Justice Brennan thought the majority opinion in Strickland could be applied in a way that would serve the goals of the Furman regime, whereas Justice Marshall re- 
was plainly correct in one sense: if it is important for the death penalty to be imposed accurately and fairly based on individual desert (and the premise of the Furman regime is that it is), then vigorous defense representation is absolutely essential. His further claim that there should be a separate standard of effectiveness ${ }^{227}$ is, however, debatable. The goals of the Furman regime could be served by a unitary standard that sets a very high baseline of effectiveness or, as Justice Brennan urged, ${ }^{228}$ a unitary standard that is phrased in general enough terms but applied more stringently in capital cases. Ultimately, what matters, as long as Furman and its progeny constitute the measure of the constitutionality of capital punishment, is that the standard governing capital cases be set high enough to make the Furman regime work.

Even so, the majority chose a different course that undermined the Furman regime. The problem was not the Strickland standard as such. As any litigator knows, error-free trials are virtually impossible, and just and reliable outcomes can be reached in spite of trial error. Moreover, retrials are quite costly, both in terms of resources and finality concerns. Therefore, the Court's basic approach-to restrict relief to cases where it is reasonably likely that serious attorney error had a detrimental effect on the outcome ${ }^{229}$ is a sensible one.

The problem, rather, was in the various meta-rules contained in Strickland. Courts were admonished not to articulate fixed constitutional rules about what attorneys should and should not do in particular circumstances because legal representation is an "art," not a science. ${ }^{230}$ Instead, judicial scrutiny "must be highly deferential," and courts "must indulge a strong presumption that counsel's conduct falls within the wide range of reasonable professional as-

jected the majority's formulation as unacceptable. Compare id. at 716 (Marshall, J., dissenting), with id. at 704 (Brennan, J., concurring in part and dissenting in part).

${ }^{227}$ See id. at 716-17 (Marshall, J., dissenting).

${ }^{228}$ See id. at 704 (Brennan, J., concurring in part and dissenting in part).

${ }^{229}$ See id. at 690-94 (majority opinion).

${ }^{230} \mathrm{ld}$. at 693 . Of course, the legal profession does generate norms to delineate professional from unprofessional behavior. Nevertheless, the majority dismissed "[p]revailing norms of practice as reflected in American Bar Association standards and the like" as "only guides." Id. at 688 . The suggestion was that conduct contrary to prevailing norms of legal practice can nonetheless constitute effective assistance of counsel for constitutional purposes. 
sistance." ${ }^{231}$ Deference is especially warranted when so-called "strategic choices" are involved. Such choices, the Court added, need not be based on "thorough investigation of law and facts relevant to plausible options," although such investigation renders attorney strategy "virtually unchallengeable." tigation might be reasonable in certain situations, and courts owe a "heavy measure of deference to counsel's judgments" about how much investigation, if any, is required. ${ }^{233}$ The message to the lower courts was unmistakable: Strickland claims are to be denied if there is any conceivable basis for rationalizing what the attorney did or failed to do.

The majority's resolution of the case before it powerfully underscored the message. The defendant had committed multiple counts of capital murder and related crimes during a bizarre, ten-day crime spree. ${ }^{234} \mathrm{He}$ not only confessed but, against his attorney's advice, pled guilty to all charges and waived his right to an advisory sentencing jury. ${ }^{235}$ Understandably, these developments caused the attorney to experience what the Court described as "a sense of hopelessness about the case," and the attorney cut short his efforts on his client's behalf. ${ }^{236}$ The attorney did not request a psychiatric evaluation of his client to try and substantiate the defendant's prior claim that he had killed under the influence of extreme mental or emotional distress. ${ }^{237}$ As for investigation into his client's background and potential character witnesses, the attorney merely had a conversation with the defendant and two relatives. ${ }^{238}$ In effect, the attorney threw his client on the mercy of the court, urging leniency because the defendant had accepted responsibility for his crimes and claimed to have been under severe emotional distress. ${ }^{239}$ Not

${ }^{231}$ Id. at 689; see also, e.g., id. at 690 ("[C]ounsel is strongly presumed to have rendered adequate assistance and made all significant decisions in the exercise of reasonable professional judgment.").

${ }^{232}$ Id. at 690-91.

${ }^{233}$ Id. at 691.

${ }^{234}$ Id. at 671-72.

${ }^{235}$ Id. at 672.

${ }^{236} \mathrm{Id}$.

${ }^{237}$ Id. at $673-74$.

${ }^{238}$ Id. at 672-73.

${ }^{239}$ Id. at 673-74. 
surprisingly, the judge was unimpressed with these arguments and imposed three death sentences. ${ }^{240}$

The Strickland majority ruled that the defendant could satisfy neither the performance nor the prejudice prongs of the test for ineffective assistance. There was little controversy over the application of the prejudice prong. As the majority noted, "[ $t]$ he aggravating circumstances were utterly overwhelming," 241 which probably explains why the prosecution felt no need to go beyond proving the nature of the crimes committed. The crimes themselves were so serious that it is difficult to believe that the outcome might have been different if the attorney had presented additional character witnesses or taken the other steps the defendant claimed he should have. ${ }^{242}$ The defendant's case was properly thrown out for lack of prejudice.

The performance prong, however, was another matter entirely. Everyone in the case agreed that the attorney had invested minimal effort in the penalty phase: aside from moving to exclude the defendant's prior record and talking to the defendant and two family members, he did nothing except plead for mercy. ${ }^{243}$ The question was whether such a minimalist effort was reasonable. Where the dissent saw an attorney giving up on his client as a lost cause, the majority saw a "strategic choice" to ignore potential grounds for mitigation based on psychological and character evidence and focus almost entirely on his client's acceptance of responsibility. ${ }^{244}$ This choice, though not the product of diligent investigation, was

\footnotetext{
${ }^{240}$ Id. at 675.

${ }^{241}$ Id. at 699.
}

${ }^{242}$ See id. at 700 . Even so, Justice Marshall was right in saying that predictions as to prejudicial effect are hazardous when ineffective assistance is at issue. Naturally, errors by the defense attorney are going to make the prosecution's case look stronger, and the client's case look more hopeless, than they would have if the defendant's attorney had been competent. See id. at 710 (Marshall, J., dissenting). Even taking this important consideration into account, it remains difficult to see how more vigorous representation could have led the trial judge to impose a life sentence. An even more serious problem with requiring defendants to show prejudice in order to obtain relief for a Strickland claim is that it takes effective assistance to prove prior ineffective assistance. If the attorney challenging the ineffectiveness of trial counsel is himself ineffective, and thus fails to discover mitigating evidence or meritorious arguments missed by trial counsel, then the defendant will lose even if his trial lawyer's errors were egregious and prejudicial.

${ }^{243}$ Id. at $672-74$ (majority opinion).

${ }^{244}$ Id. at 699. 
reasonable because psychological and character evidence would have been "of little help" if introduced and might have harmed the defendant's cause by prompting rebuttal from the prosecution. ${ }^{245}$

Here is where the Court went seriously wrong. The Court's application of the performance prong gave attorneys license to make precipitous judgments, ruling out certain lines of defense very early in the case based on speculation, and the ability to insulate those judgments against scrutiny by uttering the magic words of "strategy" or "tactics."246 Common sense suggests that lawyers cannot intelligently decide to pursue certain lines of defense over others unless they have first investigated all the pertinent options. Only then will they be in a position to exercise professional judgment, and make reasonable strategic or tactical choices, about whether to pursue all lines of defense or, if a choice is necessary, about which should and should not be pursued. If, as Strickland suggests, fear of possible rebuttal is an excuse not just for not introducing evidence on a point, but also for not investigating what the evidence might be, then even the most inept and inattentive lawyers will have an iron-clad response whenever challenged for inadequate investigation. That is because anything defense attorneys do on behalf of their clients opens the door to potential rebuttal.

In light of Strickland, it comes as no surprise that successful ineffective assistance claims are infrequent at best. As one commentator reports, "[c]ourts rarely reverse convictions for ineffective assistance of counsel, even if the defendant's lawyer was asleep, drunk, unprepared, or unknowledgeable. In short, any 'lawyer with a pulse will be deemed effective.",247

\footnotetext{
${ }^{245} \mathrm{Id}$.

${ }^{246}$ Indeed, it was not even necessary for attorneys to say the magic words because courts would eagerly supply the necessary incantation for them. In Strickland, the attorney admitted that it was a bout of "hopelessness" about the case that caused him to cut short his efforts when his client confessed and pled guilty against his advice, a fact the dissent understandably stressed. See id. at 718 (Marshall, J., dissenting). The majority, however, refused to accept the attorney's admission and said the magic words for him: "[C]ounsel made a strategic choice to argue for the extreme emotional distress mitigating circumstance and to rely as fully as possible on [the client's] acceptance of responsibility for his crimes." Id. at 699 (majority opinion).

${ }^{247}$ Stephanos Bibas, The Psychology of Hindsight and After-the-Fact Review of Ineffective Assistance of Counsel, 2004 Utah L. Rev. 1, 1 (footnotes omitted) (quoting Marc L. Miller, Wise Masters, 51 Stan. L. Rev. 1751, 1786 (1999)). The infamous "sleeping lawyer" case was Burdine v. Johnson, 231 F.3d 950 (5th Cir. 2000), vacated,
} 
The Strickland approach is a prescription for disaster in capital cases. Capital cases are incredibly complicated, and the attorneys who represent the vast majority of defendants in those casespublic defenders and appointed counsel-are subject to unusually severe resource constraints. These attorneys, caught in the vice grip of the legislative funding "squeeze," 248 often cannot adequately investigate their cases and miss what may be strong grounds for leniency. An ineffectiveness standard that tolerates minimal case preparation, attorney failures to investigate potential grounds of defense, and attorney reliance on unadorned pleas for mercy is one that allows attorney performance or other arbitrary factors to determine who gets death and who gets life-the very antithesis of the reliable, individualized determination of death eligibility that Furman mandated. This sad scenario has played out in courtrooms all across the country, ${ }^{249}$ but it was not the scenario that the Court envisioned when it allowed executions to resume in 1976. There are many capital crimes in America. Having a bad lawyer, however, was not supposed to be one of them.

\section{b. The New, "Political" Ineffectiveness Standard for Capital Cases}

A thunderbolt struck in the year 2000. In Williams $v$. Taylor, the Supreme Court for the first time overturned a death sentence under the Strickland standard. ${ }^{250}$ Over the intervening years, the Court has struck down a number of other death sentences on ineffectiveness grounds. ${ }^{251}$ Interestingly, each of these cases was subject

234 F.3d 1339 (5th Cir. 2000) (en banc), in which the defendant challenged his capital conviction on the ground that his lawyer had slept through entire portions of the trial. Rejecting the notion that prejudice should be presumed in these circumstances, the panel majority ruled that the defendant could not win without showing that he suffered Strickland prejudice as a result of something that happened while his attorney slept. Id. at 964 . The en banc court disagreed and ruled that prejudice should be presumed when a defense lawyer sleeps through substantial parts of his client's capital trial. See Burdine v. Johnson, 262 F.3d 336, 349 (5th Cir. 2001) (en banc). The panel decision in Burdine, though extreme, illustrates how dismissive many courts are when it comes to claims of ineffective assistance of counsel.

${ }^{248}$ See supra Subsection II.A.2.b.

${ }^{249}$ For some chilling accounts of indigent defendants who were sentenced to die based on gross inadequacies of representation, see Bright, supra note 118, at 1841-66.

${ }^{250} 529$ U.S. 362 (2000).

${ }^{251}$ See e.g., Rompilla v. Beard, 545 U.S. 374 (2005); Wiggins v. Smith, 539 U.S. 510 (2003). 
to the provisions of the AEDPA..$^{252}$ This is significant because the Act essentially bars federal habeas relief unless the decision of the state courts "was contrary to, or involved an unreasonable application of, clearly established Federal law." ${ }^{253}$ Despite the high hurdle for habeas relief under the statute, the Court granted relief in each of these cases, sometimes by wide margins. ${ }^{254}$

The rebuff to the state courts inherent in a ruling that they acted unreasonably in upholding the death sentences in Williams and its progeny is obvious. Less obvious is the effect that those cases have on the Strickland standard. Given that only "clearly established" law can be applied in habeas cases, the majority opinions in Williams and its progeny were written (as they had to be) as straightforward applications of Strickland. ${ }^{255}$ The dissents, however, accused the Court of going considerably beyond the law established in Strickland. ${ }^{256}$ Which side had the better of the argument?

As it turns out, both sides were right. The dissents were correct that the results reached in Williams and its progeny could not have been reached under the ineffectiveness standard as it was applied in Strickland and understood in later cases. After all, for more than a decade, courts had understood Strickland to allow even egregious errors to be excused as "strategy" and "tactics." 257 Nevertheless, the majority in Williams and its progeny was right that reflexive deference to potential "strategy" and "tactics" is fundamentally at odds with the basic standard enunciated in Strickland.

Buried amid all the unusually strong rhetoric in Strickland about the need to defer to judgments of trial counsel were two commands

${ }^{252}$ See e.g., Rompilla, 545 U.S. at 380; Wiggins, 539 U.S. at 520.

${ }^{253} 28$ U.S.C. $\$ 2254(\mathrm{~d})(1)(2000)$.

${ }^{254}$ See e.g., Wiggins, 539 U.S. at 513 (vacating Wiggins's capital sentence by a 7-2 margin).

${ }^{255}$ See, e.g., id. at 522 (claiming that Williams $v$. Taylor "made no new law" in the area of Strickland claims).

${ }^{256}$ Consider, for example, the following passage from Justice Antonin Scalia's dissent in Wiggins v. Smith:

The Court is mistaken to assert that [the] discussion [in Williams v. Taylor] 'made no new law.' There was nothing in Strickland, or in any of our 'clearly established' precedents at the time of the Virginia Supreme Court's decision, to support Williams' statement that trial counsel had an 'obligation to conduct a thorough investigation of the defendant's background.'

Id. at 542-43 (Scalia, J., dissenting) (citations omitted).

${ }^{257}$ See supra note $246-247$ and accompanying text. 
that supported the outcome in the Williams line of cases. First, absent a "reasonable decision that makes particular investigations unnecessary," counsel "has a duty to make reasonable investigations" into potential lines of defense. ${ }^{258}$ This means that the default rule under Strickland is not "no investigation" but "reasonable investigation," with limits on investigation passing constitutional muster only if those limits are themselves reasonable. Second, "strategic choices made after less than complete investigation" are reasonable only "to the extent that reasonable professional judgments support the limitations on investigation." 259 Consequently, far from being magic words, "strategy" and "tactics" are merely attorney choices that, like all other attorney choices concerning how to represent a criminal defendant, are judicially reviewable. The operative yardstick for all attorney actions-whether "strategic" in nature or not-is, as Strickland put it, "reasonableness under prevailing professional norms."260 These vital statements, though ignored in the years following Strickland, disprove the notions that defense attorneys need not investigate their clients' cases and that attorney missteps are effectively unreviewable if those missteps can be recharacterized as "strategy" or "tactics."

As a consequence, the new ineffectiveness cases do change the prior understanding of the Strickland standard as it applies to capital cases. They do so, however, not by adopting standards different from those enunciated in Strickland. Rather, they do so by returning to the principles announced in Strickland and freeing the Strickland standard from the misinterpretation that had all but rendered the right to effective assistance of counsel a dead letter.

This reinterpretation of Strickland seems to reflect an appreciation of the deleterious effect of the politics of death on the administration of the death penalty. Capital defenders are notoriously underfunded, particularly in states, like Texas and Virginia, that lead the nation in executions. ${ }^{261}$ This creates the danger that subpar performance by resource-constrained defense attorneys will undermine the larger project under Furman of reserving the death penalty for the worst of death-eligible defendants. The vital linkage

\footnotetext{
${ }^{258}$ Strickland, 466 U.S. at 691.

${ }^{259}$ Id. at $690-91$.

${ }^{260}$ Id. at 688.

${ }^{261}$ See supra Subsection II.A.2.b.
} 
between effective defense representation and fair administration of capital punishment, apparent only to Justices Brennan and Marshall in Strickland, now appears to be more widely understood among the Justices.

A 2001 speech by Justice O'Connor, author of Strickland, to a Minnesota women's bar group is revealing in this regard. In that unusually candid speech, she expressed serious doubts "about whether the death penalty is being fairly administered in this country." ${ }^{262}$ Her concern was much broader than the danger of executing an innocent person someday. ${ }^{263}$ She worried that the sentences guilty defendants receive in capital cases frequently turn on how well-or how poorly-their attorneys perform. ${ }^{264}$ As proof, she cited grisly statistics from Texas mdicating that indigents are significantly more likely to be executed than persons of means due to the lower quality of representation that indigents receive ${ }^{265}$ The real problem with the death penalty, in other words, is not death, but its politics.

The Williams line of cases addresses two important issues concerning attorney performance at capital sentencing hearings. First, to what extent, if any, are courts permitted to scrutinize strategic choices made by capital defenders? Second, what are the contours of the defense attorney's duty to investigate potential grounds for leniency and potential grounds for countering the prosecution's aggravation evidence? Each issue is discussed, in turn, below.

\footnotetext{
${ }^{262}$ Maria Elena Baca, O’Connor Critical of Death Penalty, Star Trib. (Minn.), July 3, 2001, at A1 (quoting Justice O'Connor).

${ }^{263}$ See id.

${ }^{264}$ See id.

${ }^{265}$ Id. ("In Texas last year, [O'Connor] said, those who were represented by appointed defense attorneys were 28 percent more likely to be convicted than were those who had retained their own attorneys; if convicted, they also were 44 percent more likely to be sentenced to death."). Based on this phenomenon, Justice O'Connor surmised that "it's time to look at minimum standards for appointed counsel in death cases and adequate compensation for appointed counsel when they are used." Id.
} 
i. Strategy versus "Strategery"2066

A key component of the new approach to ineffectiveness claims is that the Supreme Court now understands the need to distinguish serious attorney errors from strategic moves in capital cases. It is all too easy for an attorney, embarrassed by having the effectiveness of his representation challenged by a former client, to cast errors of judgment, inattention, or even indolence as tactical moves that, as (bad) luck would have it, ended in disaster for the client. Today, the Court views self-serving claims by capital defenders of "strategy" and "tactics" with a jaundiced eye and endeavors to evaluate the reasonableness of the actions the attorneys took on behalf of their clients.

The most striking example of this newfound suspicion of claims of "strategy" and "tactics" is Wiggins v. Smith ${ }^{267}$ In that case, the public defenders had social services records indicating that their client had suffered an abusive childhood and had experienced emotional difficulties in his youth as he was shuttled among various foster homes ${ }^{268}$ Based on their own statements at the penalty phase, the defense knew that these records suggested that "'Kevin Wiggins has had a difficult life"" and that "'[life] has not been easy for him..",269

Nevertheless, the defense did not follow up on the leads contained in the social services records. They did not even follow the local practice of requesting a "social history" for their client, which under state law would have been prepared for the defense, free of charge, by a social worker if they had requested it ${ }^{270}$ As a consequence, counsel went into the sentencing phase ignorant of other records showing, in even more graphic detail, that the defendant had suffered what the Supreme Court characterized as an "excru-

\footnotetext{
${ }^{266}$ See generally Wikipedia, Strategery, http://en.wikipedia.org/wiki/Strategery (last visited Oct. 7, 2007) (explaining that "strategery" originated in a Saturday Night Live sketch parodying the 2000 presidential debate when the word was used by the actor playing George W. Bush as a "mock-Bushism playing on the words 'strategy' and "strategic" and "satirizing Bush's reputation for mispronouncing words"). The term "strategery" is used here to refer not to presidential malapropisms, but rather to tactics that purport to be strategy but are anything but strategic.

${ }^{267} 539$ U.S. $510(2003)$.

${ }^{268}$ Id. at $523-25$.

${ }^{269}$ Id. at 515 (quoting defense counsel's opening statement).

${ }^{270}$ Id. at 524.
} 
ciating life history," replete with severe physical and sexual abuse. ${ }^{271}$ Counsel also failed to present the records they did have, or any other evidence, concerning the defendant's "difficult life.",272 Consequently, the only argument from the defense against a death sentence was that someone else had killed the victim and that Wiggins had no prior convictions. The jury imposed death, and the state courts rejected Wiggins's claim of ineffective assistance of counsel. ${ }^{273}$

The state trial court's rejection of the ineffectiveness claim was particularly jarring - and particularly probative of the effects of the politics of death on judicial decisionmaking - because the trial judge thought it was a serious mistake not to request a social history for a capital defendant. As the judge said, “'[n]ot to do a social history, at least to see what you have got, to me is absolute error. I just-I would be flabbergasted if the Court of Appeals said anything else."'274 "Absolute error" or not, the judge and the Maryland Court of Appeals rejected the ineffectiveness claim and upheld Wiggins's death sentence. ${ }^{275}$

The result was lopsided in the Supreme Court: seven Justices voted to reverse. The Court refused to defer to counsel's purported strategic decision not to expand their investigation into the defendant's background or request a social history. The claim of tactics was dismissed as a "post hoc rationalization," instead of an accurate explanation of counsel's actions. ${ }^{276}$ As the Court put it, the premature decision by counsel to abandon the search for evidence of their client's history of victimization and abuse "resulted from inattention," the very antithesis of the professional judgment and

${ }^{271}$ Id. at 537 . The abuse included multiple episodes of sexual molestation and outright rape while in various foster care facilities. Id. at 517 . It also included being regularly abandoned as a child, along with his siblings, and having no source of food for days on end other than "beg[ging] for food" and "eat[ing] paint chips and garbage." Id. at 516-17. See generally id. at 516-18 (discussing results of social history prepared on later postconviction review).

${ }^{272}$ Id. at 515, 523-24. Further investigation into the defendant's background would have been costless because the public defender's office had obtained funding to have licensed social workers investigate the client's background and prepare a "social history." Id. at 524.

${ }^{273}$ Id. at $516-18$.

${ }^{274}$ Id. at 517.

${ }^{275}$ Id. at $517-18$.

${ }^{276}$ Id. at $526-27$. 
skill that attorneys are obligated to bring to bear on behalf of their clients. ${ }^{277}$

Furthermore, Wiggins held that, even if treated as a strategic matter, the decision to rely on other grounds of defense was an unreasonable one for two reasons. First, it was "standard practice" in Maryland capital cases to have a social history prepared to uncover potential mitigating evidence, and there was no reason to have done otherwise here. ${ }^{278}$ Second, regardless of local practice, before counsel could make a reasonable strategic choice not to present background evidence in mitigation, they had to conduct a reasonable investigation into their client's background. Until such an investigation had been conducted, the majority wrote, "counsel were not in a position to make a reasonable strategic choice" as to whether or not to present background evidence. ${ }^{279}$

As Wiggins demonstrates, the Supreme Court has finally put an end to the "magic words" approach to ineffectiveness claims in capital cases. Inattention or errors of judgment can no longer be dressed up after the fact as "strategy" or "tactics." The Court looks to the actual basis for attorney decisions, not post hoc rationalizations for decisions reached on other, less supportable grounds. Moreover, even decisions that are properly viewed as "strategic" in nature are not immune from judicial scrutiny. Strategic decisions are entitled to deference under Strickland only if they were made on the basis of reasonable professional judgment after diligent investigation of the pertinent facts. Anything less than that is "strategery," not "strategy."

\section{ii. Duty and Scope of Investigation}

The recent ineffectiveness cases, beginning with Williams $v$. Taylor, reject the notion that defense attorneys preparing for capital

${ }^{277}$ Id. at 526. Interestingly, that harsh assessment of counsel's performance came from none other than Justice O'Connor, who had also written for the majority in Strickland. In Strickland, she worried that questioning decisions by defense attorneys "could dampen the ardor and impair the independence of defense counsel, discourage the acceptance of assigned cases, and undermine the trust between attorney and client." 466 U.S. at 690 . By the time of Wiggins, however, Justice O'Connor was perfectly willing, not just to disbelieve self-serving claims of "strategy," but to chide defense counsel for inattention to their cases.

${ }^{278}$ Wiggins, 539 U.S. at 524.

${ }^{279}$ Id. at 536. 
sentencing hearings have unfettered discretion over investigative matters. It is now clear that, absent contrary direction from their clients, defense attorneys have a duty to investigate all reasonably available potential grounds for avoiding a death sentence, such as evidence in mitigation and even evidence countering the aggravating circumstances invoked by the prosecution. The defense attorney's investigation into potential grounds for avoiding a death sentence need not be exhaustive, but it must be sufficiently complete to enable the attorney to exercise reasonable professional judgment as to how to maximize the chances that the sentencing phase will end in a sentence other than death. Courts can no longer send defendants to their deaths when, by virtue of inadequate investigation or unreasonable decisions by defense lawyers, jurors were denied the opportunity to hear strong grounds for choosing life over death.

\section{a. Mitigation Evidence}

Williams $v$. Taylor addressed the basic duty to investigate potential grounds for mitigation at capital sentencing hearings. The defense attorneys in that case threw their client on the mercy of the court, without ever looking for mitigating evidence in his background. ${ }^{280}$ The Williams majority overturned the resulting death sentence, holding that the defense attorneys were ineffective for "not fulfill[ing] their obligation to conduct a thorough investigation of the defendant's background." 281

Wiggins $v$. Smith picked up where the Court left off in Williams. Although the defense attorneys in Wiggins had investigated their client's background, they cut their inquiry short and elected to advance other arguments for a life sentence. They did so notwithstanding early results showing that the defendant had been physi-

\footnotetext{
${ }^{280}$ Williams v. Taylor, 529 U.S. 362,369 (2000).

${ }^{281}$ Id. at 396. In support of the notion that defense attorneys must conduct thorough investigations, the Court cited the American Bar Association's standards for the defense function. See id. (citing 1 Standards for Criminal Justice $\$ 4-4.1(1980)$ ). This was significant because Strickland had dismissed such professional standards as mere "guides" that did not necessarily establish the level of performance that the Constitution requires. See supra note 230 .
} 
cally and sexually abused as a child-strong potential mitigation evidence. ${ }^{282}$

Building on the holding in Williams concerning the contours of the basic duty to investigate, the Court reversed Wiggins's death sentence based on ineffective assistance of counsel. The Court ruled that "investigations into mitigating evidence 'should comprise efforts to discover all reasonably available mitigating evidence." "283 Once the search for mitigating evidence is underway, counsel must continue the search until such time as it becomes reasonable to conclude that further efforts are likely to be either "counterproductive" or "fruitless." ${ }^{284}$ No such point had been reached in Wiggins, the Court concluded, because even preliminary investigation into the client's background had generated helpful leads that, if pursued, might have yielded strong evidence in mitigation. ${ }^{285}$

Together, Williams and Wiggins amount to a strong mandate that defense attorneys in capital cases take very seriously their professional obligation to look for reasons to spare their clients' lives. No longer can defense attorneys abandon their clients as lost causes and go into capital sentencing hearings with only pleas for mercy or half-hearted efforts to prove that their clients deserve leniency. Rather, attorneys must thoroughly investigate their clients' background and other potential sources of mitigating evidence. Although such investigation is resource-intensive, the Supreme Court has made clear that it will no longer allow people to be executed because the attorneys assigned to their cases cut corners in the search for mitigating evidence or abandoned mitigation defenses without first developing the relevant facts. ${ }^{286}$ By using the constitutional guarantee of effective assistance of counsel to ratchet up the

\footnotetext{
${ }^{282}$ Wiggins, 539 U.S. at 524-25.

${ }^{283}$ Id. at 524 (quoting Guidelines for the Appointment and Performance of Counsel in Death Penalty Cases $\S 11.4 .1(C)$ (1989)) (emphasis in opinion).

${ }^{284}$ Id. at 525.

${ }^{285}$ See id. ("[A]ny reasonably competent attorney would have realized that pursuing these leads was necessary to making an informed choice among possible defenses.").

${ }^{285}$ It is, of course, a different case entirely if the defendant instructs the attorney not to investigate or present mitigation evidence or otherwise affirmatively prevents the attorney from doing so. In that event, the fault for the unavailability of mitigation evidence at sentencing, and the resulting death sentence, lies with the defendant himself, not the attorney. See Schriro v. Landrigan, 127 S.Ct. 1933, 1942 (2007).
} 
standard of representation indigent defendants must receive at capital sentencing hearings, the Court has taken great strides toward ensuring that jurors will get a more accurate picture of the "life" side of the life/death balance that they must strike.

With its decisions in Williams and Wiggins, the Supreme Court has turned a major corner in its decades-long effort to rationalize the imposition of the death penalty. In prior decades, the politics of death undermined the Court's reform efforts by skewing the life/death balance in favor of death. Legislators lavished funding on prosecutors while grossly underfunding indigent defense, and courts demanded-and indigent defendants received-shockingly little effort by defense attorneys at capital sentencing hearings, all too often leaving jurors with little or no basis for granting leniency. The Court's dramatic recent emphasis on raising the quality of representation in capital cases has powerfully counteracted the politics of death. Now, prosecutors can no longer bank on errors or inattention by capital defenders to bolster weak death cases, and defense attorneys can rely no longer on a toothless constitutional standard of effective representation to excuse their errors, lack of effort, and sheer unpreparedness. Defense attorneys must now do more than simply throw their clients on the mercy of the court; they must, on pains of being branded guilty of ineffective assistance, develop the facts necessary to make leniency a credible option for someone who committed a horrible crime. In cases where attorney diligence results in the discovery of grounds for mitigation that otherwise would have been missed, jurors will have better information concerning whether or not death is deserved-and better information for capital juries translates into a fairer, more accurate determination of the proper sentence.

\section{b. Aggravation Evidence}

Mitigating evidence, though of undeniable importance at a capital sentencing hearing designed to determine whether a person convicted of a capital crime should be granted leniency, constitutes only one of the weights in the balance that capital jurors must strike. The other is aggravating evidence: evidence concerning whether or not the crime involved circumstances that potentially warrant a sentence of death. By disproving one or more of the aggravating factors identified by the prosecution, defense attorneys 
can minimize the likelihood that their clients will be sent to death row, quite apart from what happens on the mitigation side of the case. Nevertheless, for reasons that are explained below, resource constraints give capital defenders strong incentives to ignore the aggravating evidence-a strategy which will not only result in stronger aggravation cases for the prosecution but also, in some cases, weaker mitigation cases for the defense as well.

\section{Aggravating Circumstances and Death's Politics}

Ideally, capital sentencing hearings would involve a truly adversarial testing of both aggravation and mitigation evidence. The adversarial testing of evidence, after all, is the vehicle through which truth will ultimately emerge. This can happen in capital sentencing hearings only if both the prosecution and the defense are able and willing to challenge each other's claims about whether or not death is the appropriate sentence. The politics of death, however, have prevented realization of this ideal. Capital sentencing hearings occur in a resource-constrained world of disparate funding-a world in which indigent defenders are significantly underfunded as compared to prosecutors. ${ }^{287}$ An incidence of the politics of death, the disparate funding has enormous implications for the fairness and reliability of capital sentencing hearings. Whereas prosecutors have the resources necessary to fight on both the aggravation and mitigation fronts, that is a luxury that severely resource-constrained defense attorneys lack.

With limited resources, capital defense attorneys have strong incentives to dismiss investigation into the aggravating factors as a low-yield proposition that is not worth the effort. After all, if there were readily available evidence that could be used to disprove an aggravating circumstance, the prosecutor would likely have known about it and, presumably, would not have invoked an aggravating circumstance that could be readily disproven. ${ }^{288}$ Consequently, from

\footnotetext{
${ }^{287}$ See supra Subsection II.A.2.b.

${ }^{288}$ Unless the case for death is exceptionally weak, prosecutors should not need to rely on weak aggravating factors. The list of potential aggravating factors tends to be long and growing, and legislatures tend to write statutory aggravating factors in broad, capacious terms. See supra note 50 . Under these circumstances, it should not be terribly difficult in most cases for prosecutors to identify one or more aggravating factors without relying on weak aggravating factors.
} 
the perspective of resource-constrained defense attorneys, the remainder of their limited resources after the guilt phase would almost always seem to be more wisely invested in building mitigation cases instead of exploring ways to counter aggravation evidence.

Although this might seem like a reasonable trade-off in the abstract, it can have disastrous consequences in real-world cases. The problem is two-fold. First, if indigent defenders focus on mitigation to the exclusion of aggravation, the aggravation cases may appear to be stronger than they actually are. Second, redirecting defense resources from investigations into aggravation evidence to investigations into mitigation evidence can, ironically enough, result in weaker mitigation cases.

The first problem is fairly straightforward. If defense attorneys do not bother to investigate aggravation evidence, the prosecution's aggravation case will go completely unchallenged. Even if such investigation would make no difference to the outcome in many cases, this will not invariably be the case. Unless defense attorneys actually investigate the aggravating circumstances cited by the prosecution, they may well miss valuable opportunities to undermine the aggravation evidence. ${ }^{289}$

The second problem, that mitigation cases might well be weaker if defense attorneys ignore the aggravation side of the case, is less obvious but even more significant to the life/death balance jurors must strike. Theoretically, capital sentencing proceedings can be disaggregated into two discrete issues: whether the defendant's crime is eligible for the death penalty (aggravation) and, if so, whether the defendant nonetheless lacks the moral culpability necessary for the ultimate sanction (mitigation). In the real world of litigation, however, the two issues are not so neatly divided.

\footnotetext{
${ }^{289}$ Furthermore, if capital defenders routinely fail to investigate and challenge aggravation evidence, a moral hazard problem may arise for prosecutors. If prosecutors can expect their aggravation evidence to go unchallenged most of the time, they will have incentives to push the envelope in their aggravation cases-for cxample, by "cherry-picking" the evidence (presenting aggravating circumstances but not extenuating circumstances known to them) or by presenting unreliable or even misleading evidence. Under normal circumstances, this behavior is self-deterring, to a large extent, because opposing counsel can be expected to expose it. With that check so often absent at capital sentencing hearings, however, overzealous prosecutors in emotionally charged proceedings may give in to temptation.
} 
Rather, the issue at any capital sentencing hearing is the singular one of whether or not the defendant should be put to death.

If defense attorneys took the same holistic approach to the issue that prosecutors do by virtue of their greater resources, defense attorneys would look for grounds for contesting the aggravating circumstances as well as grounds for establishing mitigating circumstances. The investigation of the aggravating circumstances might well yield evidence that would be helpful in building a mitigation case. Rompilla v. Beard is a case in point: there, a court file containing the aggravation evidence cited by the prosecutor contained strong mitigation evidence, but the defense attorneys never found it because they ignored the aggravating evidence. ${ }^{290}$ As Rompilla shows, helpful evidence can be found almost anywhere, in both obvious and not so obvious locations. That is why good investigators "leave no stone unturned," as the saying goes, in the search for evidence. Failure to do likewise in capital cases will deny defense attorneys (and, ultimately, jurors) the opportunity to see the full picture, with the case for a life sentence presented as vigorously as the case for death.

\section{The New Duty to Investigate Aggravation Evidence}

In Rompilla v. Beard, the Supreme Court took direct aim at the capital defenders' practice of ignoring aggravation evidence. ${ }^{291}$ The prosecution sought to prove an aggravating factor with testimony from someone whom the defendant had attacked decades earlier under allegedly similar circumstances. ${ }^{292}$ Nevertheless, the public defenders representing the defendant did not even investigate the prior crime, much less challenge the prosecution's evidence. ${ }^{293}$ The defense succeeded in establishing two mitigating circumstances, but, in the jury's view, the aggravating circumstances outweighed them..$^{24}$

The Supreme Court reversed the death sentence. Although the defense attorneys had investigated possible grounds for mitigation,

${ }^{290} 545$ U.S. 374 (2005). Rompilla is discussed in more detail at infra notes 291-303 and accompanying text.

${ }^{291} \mathrm{Id}$.

${ }^{292}$ Id. at $383-84$.

${ }^{203}$ Id. at $384-85$.

${ }^{294}$ Id. at 378 . 
that did not excuse their failure to investigate the circumstances of the prior crime cited in aggravation. As Justice David Souter wrote for the majority, it "flouts prudence to deny that a defense lawyer should try to look at a file he knows the prosecution will cull for aggravating evidence." 295 This is because defense attorneys who fail to investigate the aggravating factors on which the prosecution intends to rely at the penalty phase "seriously compromis[e] their opportunity to respond to a case for aggravation" and run the risk that prosecutors will overstate the aggravation evidence. ${ }^{296}$

As a result, attorneys cannot, consistent with the constitutional guarantee of effective assistance of counsel, investigate mitigation evidence to the exclusion of the aggravation evidence. On this point, the Court was unequivocal. The Court flatly declared, "[i]t is the duty of the lawyer to conduct a prompt investigation of the circumstances of the case and to explore all avenues leading to facts relevant to the merits of the case and the penalty in the event of conviction.","297

The duty to investigate is not necessarily as sweeping as the language from Rompilla might suggest. The operative test remains what a "reasonable lawyer" would do in preparation for a capital sentencing hearing. ${ }^{298}$ A lawyer could reasonably decide not to pursue a line of investigation that amounts to a fishing expedition or would be so boundless and resource-intensive as to be impracticable. Consequently, the Rompilla majority cautioned that a defense lawyer is not required to "look[] for a needle in a haystack, when a lawyer truly has reason to doubt there is any needle there," or to examine "warehouses of records" in the search for helpful evidence. ${ }^{299}$ In such circumstances, reasonable attorneys will, of necessity, impose limits on the scope of their investigation.

Nevertheless, evidence that defense attorneys know will be used in aggravation is in a very different category. As the Court de-

\footnotetext{
${ }^{295}$ Id. at 389.

${ }^{296}$ Id. at 385-86.

${ }^{297}$ Id. at 387 (emphasis added) (quoting 1 Standards for Criminal Justice $\$ 4-4.1$ (Supp. 1982)).

${ }^{298}$ Id. at 389; see also id. at 381 (stating that attorney performance is measured against a "standard of reasonableness applied as if one stood in counsel's shoes").

${ }^{299}$ Id. at 389,386 n.4; see also id. at 382-83 (referring to "this Court's recognition that the duty to investigate does not force defense lawyers to scour the globe on the off chance something will turn up").
} 
clared, "defense counsel must obtain information that the State has and will use against the defendant [in aggravation]." ${ }^{" 300}$ This duty is so important to the accuracy of the adjudication process in general, and of the capital sentencing process in particular, that the majority was unable to "think of any situation in which defense counsel should not make some effort to learn the information in the possession of the prosecution and law enforcement authorities." 301 Therefore, in order to render effective assistance at the penalty phase of a capital case, defense counsel must make reasonable efforts to investigate the aggravating factors cited by the prosecution and, more generally, to find out everything that the government knows about the case.

Even more interesting than what Rompilla had to say about the duty to investigate is the context in which the Court said it. One might infer from the pronouncements in Rompilla that the defense team missed available grounds for countering the prosecutor's claim that the prior crime was an aggravating factor. That, however, was not the case.

Although the defective performance in Rompilla was the failure to investigate the aggravating factors, the prejudice concerned missed evidence in mitigation. Had the defense attorneys searched the court file on the prior crime for grounds to counteract the prosecutor's aggravation evidence, the majority ruled, they "would have found a range of mitigation leads that no other source had opened up." ${ }^{302}$ Given that the prejudice came from failure to discover strong mitigation evidence, the most direct route to reversal

${ }^{300}$ Id. at 387 (emphasis added); see also id. ("The investigation should always include efforts to secure information in the possession of the prosecution and law enforcement authorities." (quoting 1 Standards for Criminal Justice $\$ 4-4.1$ (Supp. 1982))).

${ }^{301}$ Id. at 387 n.6. That was most certainly true in Rompilla, as Justice O'Connor forcefully argued in her concurring opinion:

$[T]$ he prosecutor clearly planned to use details of the prior crime as powerful evidence that Rompilla was a dangerous man for whom the death penalty would be both appropriate punishment and a necessary means of incapacitation. This was evidence the defense should have been prepared to meet: A reasonable lawyer would have attached a high importance to obtaining the record of the prior trial, in order to anticipate and find ways of deflecting the prosecutor's aggravation argument.

Id. at 394 (O'Connor, J., concurring) (citation omitted).

${ }^{302}$ Id. at 390. 
in Rompilla would have been to reject the mitigation investigation as unreasonable, as Williams and Wiggins had done. Nonetheless, the Rompilla majority took a more circuitous route, reasoning that if the attorneys had diligently investigated the aggravating factors, they would have, as the dissent tendentiously put it, "stumbled across" previously undiscovered mitigation evidence revealing a history of severe mental illness, child abuse, and alcoholism. ${ }^{303}$

Rompilla is significant because it forces defense attorneys to approach capital sentencing hearings in the same holistic fashion that prosecutors do. Instead of focusing their investigative efforts just on "their" part of the case (namely, the mitigation case), defense attorneys must investigate the entire case. By pushing defense attorneys to try to learn as much as they can about the case as a whole-and, ideally, everything that the government knows about the case $\mathrm{c}^{304}$ - the constitutional duty to investigate serves not just as a shield but also as a sword. It operates as a shield in that it obligates capital defenders to search diligently for mitigating evidence, in both obvious and less obvious places, that might be used to convince jurors to spare the defendant's life even though his crime might otherwise merit death. It also operates as a sword by obligating defense attorneys in capital cases to be alert for opportunities to go on the offensive by undercutting the prosecution's aggravating evidence, either by showing that the defendant's crime is not even death eligible in the first place or, more often, by minimizing the weight of the aggravating factors and increasing the chance that the mitigating factors will outweigh the aggravating factors. To the extent both sides of the life/death balance will now be subjected to

${ }^{303}$ Id. at 405 (Kennedy, J., dissenting). As Justice Anthony Kennedy argued, "[t]he Court's theory of prejudice [under Strickland] rests on serendipity .... If Rompilla's attorneys had reviewed the case file of his prior rape and burglary conviction, the Court says, they would have stumbled across "a range of mitigation leads." Id. (quoting 545 U.S. at 390). The Court took such an indirect route to its outcome because it was hamstrung by the restrictive AEDPA standard of review. Although clearly troubled by the shortcuts defense counsel had taken in searching for mitigation evidence, whieh led the defense to miss clues that led postconviction counsel to school, medical, and prison records containing powerful mitigation evidence, the Court found "room for debate" about the reasonableness of the mitigation investigation. Id. at 383 . Under the AEDPA, habeas relief may not be granted under those circumstances. See supra note 175 . This explains why the Strickland violation was based on the deficiency of the aggravation investigation instead of the mitigation investigation.

${ }^{304}$ See Rompilla, 545 U.S. at 385-87. 
meaningful adversarial testing, instead of just the mitigation side of the balance, the balance that jurors ultimately strike is more likely to reflect true individual desert, as Furman v. Georgia and its Eighth Amendment progeny demand, rather than arbitrary factors such as attorney performance and resource differentials between prosecution and defense.

\section{c. The Politics (and Promise) of the New Ineffectiveness Standard}

The line of ineffective assistance cases that began with Williams $v$. Taylor is dramatic in the emphasis it places on the quality of representation defendants receive in capital cases. In prior decades, the Supreme Court tolerated even blatant attorney errors that resulted in death sentences that might not otherwise have been imposed. Now, in contrast, it has demanded that attorneys representing defendants charged with capital crimes diligently and carefully perform their professional responsibilities, both in court proceedings and, as importantly, in conducting the factual investigation on which the search for truth in court depends. In doing so, the Court has finally ended the schizophrenia that has characterized its approach to the death penalty over the last few decades. Furman $v$. Georgia required valid capital punishment schemes to administer death in a rational, even-handed manner based on individual desert. ${ }^{305}$ While the Furman Court struggled to use the Eighth Amendment to bring rationality and fairness to the imposition of capital punishment, the Sixth Amendment cases, beginning with Strickland $v$. Washington, ${ }^{306}$ adopted such a low standard of defense attorney performance that whether or not death would actually be imposed turned, to a disturbing extent, on how well (or how poorly) the lawyers assigned to represent the defendant performed.

So, at the same time Eighth Amendment cases insisted on a scientific balancing of aggravating and mitigating factors as the determinant of whether or not death is morally deserved in a particular case, Sixth Amendment cases all but guaranteed that the balance would be skewed in favor of death. By virtue of attorney error and inadequate investigation on the defense side-problems rooted in the serious underfunding of indigent defense representa-

\footnotetext{
${ }^{305} 408$ U.S. 238 (1972) (per curiam).

${ }^{306} 466$ U.S. 668 (1984).
} 
tion by legislatures and facilitated by a toothless constitutional standard of effective assistance-the aggravating factors appeared weightier, and the mitigating factors far less substantial, than those factors may actually have been. The insistence, in recent ineffective assistance cases, on a much higher standard of representation by capital defenders addresses this long-standing anomaly by giving jurors a more accurate picture of the facts and circumstances bearing on whether the defendant is eligible for, and deserving of, a sentence of death. Greater information from the defense for jurors at the penalty phase, as to both the aggravating and mitigating circumstances, translates into a greater likelihood that the ultimate sanction will truly be limited to the offenders most deserving of it.

At this point, an important matter of scope should be considered. The right to effective assistance of counsel applies to noncapital cases no less than capital cases. ${ }^{307}$ The new approach, however, has been applied only in capital cases. ${ }^{308}$ As a result, defense attorneys are now being held to a considerably higher standard of representation in capital cases than in other kinds of criminal cases. Obviously, the Court believes that capital cases are somehow different from cases involving lesser sanctions, but what is the relevant difference? The following Subsections address this question.

\section{i. "Death Is Different"}

The most obvious difference is the sanction involved. One might view the Williams $v$. Taylor line of cases as merely another example of "death is different" jurisprudence. To be sure, the premise of

\footnotetext{
${ }^{307}$ See, e.g., Kimmelman v. Morrison, 477 U.S. 365, 383-91 (1986) (entertaining a Strickland challenge to a conviction for rape).

${ }^{308}$ See Rompilla v. Beard, 545 U.S. 374, 377 (2005); Wiggins v. Smith, 539 U.S. 510 , 521-34 (2003); Williams v. Taylor, 529 U.S. 362, 390-96 (2000). Outside of capital cases, the Court still applies the language from Strickland mandating extreme deference to defense attorney choices regarding how to represent a client. For example, in Roe v. Flores-Ortega, 528 U.S. 470 (2000), the Court ruled that trial attorneys are not necessarily ineffective if they fail to consult with their clients about their right to appeal or allow the time for appeal to expire without ensuring that their clients truly do not want to appeal. Id. at 478-80. Although it agreed with American Bar Association standards that "the better practice is for counsel routinely to consult with the defendant regarding the possibility of an appeal," the Court concluded that "“[p]revailing norms of practice as reflected in [ABA] standards and the like ... are only guides,' and imposing 'specific guidelines' on counsel is 'not appropriate."' Id. at 479 (quoting Strickland, 466 U.S. at 688).
} 
the Furman regime is that death, by virtue of its severity and irreversibility, is different from lesser punishments and thus calls for heightened procedural safeguards. ${ }^{309}$ The "death is different" premise, however, is not what lies behind the new approach to the Sixth Amendment guarantee of effective assistance in capital cases. The Court remains committed to the Strickland standard, which is premised on the view that the sanction involved in a capital case is not sufficient reason to hold attorneys representing defendants charged with capital crimes to a higher standard of representation. ${ }^{310}$ None of the recent ineffectiveness cases have repudiated that view.

Indeed, the suggestion that the Eighth Amendment notion that "death is different" has crept into recent Sixth Amendment decisions is difficult, at best, to reconcile with two of those decisions. The first is Mickens $v$. Taylor, ${ }^{311}$ a case decided two years after Williams v. Taylor. The second is Schriro v. Landrigan, ${ }^{312}$ the Supreme Court's latest ineffective-assistance case.

In Mickens, the defendant was sentenced to death after a trial at which he was represented by the same court-appointed lawyer who had previously represented the person the defendant murdered, a situation that presented an obvious conflict of interest. ${ }^{313}$ It was undisputed that the state trial court knew of the potential conflict, yet, in violation of its constitutional duty, it failed to inquire into the propriety of the representation; the only question was whether reversal was automatic upon proof of a breach of that duty or whether, in addition, the defendant had to show that the conflict materialized and adversely affected his attorney's performance. ${ }^{314}$

\footnotetext{
${ }^{309}$ See generally Steiker \& Steiker, supra note 16 , at $397-401$.

${ }^{310}$ See Strickland, 466 U.S. at 687 (concluding that capital sentencing hearings "need not be distinguished from an ordinary trial"). The Strickland test's failure to require a higher standard of effectiveness in capital cases was one reason that Justice Marshall found the test objectionable. Id. at 716 (Marshall, J., dissenting).

${ }^{311} 535$ U.S. 162 (2002).

${ }^{312} 127$ S. Ct. 1933 (2007).

${ }^{313} 535$ U.S. at $164-65$.

${ }^{314}$ See id. at $185 \mathrm{n} .9$ (Stevens, J., dissenting) (stating that there was "no dispute" that the conflict was known to the trial judge); see also id. at 166-67, 174. In Cuyler v. Sullivan, 446 U.S. 335 (1980), the Court had held that trial judges who "know[] or reasonably should know that a particular conflict [of interest] exists" have a constitutional obligation to inquire into whether new, conflict-free counsel should be appointed. Id. at 347. Sullivan also held that the necessary showing to obtain reversal
} 
"Death is different" rhetoric surfaced at various points, but only in the dissents. ${ }^{315}$

The majority gave no indication that attorney conflicts of interest were less tolerable in capital cases. To the contrary, the majority made it considerably more difficult for death-row inmates to obtain relief for attorney conflicts. In all cases, the Court held, defendants who failed to object to representation by an attorney with a potential conflict of interest can obtain relief only by proving the conflict adversely affected the performance of their attorneys. ${ }^{316}$ Shortly after the Court's ruling, Mickens was executed. ${ }^{317}$

Landrigan was, in certain respects, a reprise of Williams $v$. Taylor and its progeny. The defense attorney entered the sentencing phase with very little preparation and failed to investigate several categories of potential mitigating evidence. ${ }^{318}$ The key difference from prior ineffectiveness cases was that the defendant in Landrigan "refused to allow the presentation of any mitigating evidence." ${ }^{319}$ Despite the minimal effort of the attorney at the investi-

for attorney conflicts depended on whether or not the defendant had objected to representation by a "conflicted" attorney: if the trial court failed to inquire into the matter despite objection, automatic reversal was required, but the more stringent showing of adverse effect stemming from an actual conflict of interest had to be made if there was no such objection and the trial court was otherwise without reason to know of the conflict. Id. at 348. It was unclear what the defendant's burden of proof was under Sullivan in a case like Mickens, where there was no objection but the trial judge nevertheless knew or should have known about the conflict.

${ }^{315}$ See, e.g., Mickens, 535 U.S. at 189 (Stevens, J., dissenting) ("Setting aside Mickens'[s] conviction is the only remedy that can maintain public confidence in the fairness of the procedures employed in capital cases. Death is a different kind of punishment from any other that may be imposed in this country."); id. at 210 (Breyer, J., dissenting) ("[T]he conflict is exacerbated by the fact that it occurred in a capital murder case."); id. at 211 ("[T]he Commonwealth [of Virginia] seeks to execute a defendant, having provided that defendant with a lawyer who, only yesterday, represented the victim. In my view, to carry out a death sentence so obtained would invariably 'diminis[h] faith' in the fairness and integrity of our criminal justice system." (quoting Young v. United States ex rel. Vuitton et Fils S.A., 481 U.S. 787, 811-12 (1987) (plurality opinion))).

${ }^{316}$ See Mickens, 535 U.S. at 173-74.

${ }^{317}$ See supra note 197.

${ }^{318}$ Landrigan, 127 S. Ct. at 1939.

${ }^{319}$ Id. at 1942 (distinguishing Williams, Wiggins, and Rompilla). When the lawyer attempted to present the mitigating evidence known to him, the defendant repeatedly interrupted him. The defendant ultimately instructed the lawyer, and advised the trial judge, that he did not want any mitigating evidence to be presented on his behalf. $\mathrm{He}$ went on essentially to "volunteer" for the death penalty, saying to the judge: "I think 
gative stage, the Court rejected the defendant's ineffective assistance claim and upheld his death sentence ${ }^{320}$ In the Court's view, it was reasonable for the state trial court to conclude that Strickland prejudice cannot be shown where the client "interferes with counsel's efforts to present mitigating evidence to a sentencing court.",321

Whatever else might be said of Mickens and Landrigan, they disprove the notion that it is opposition to the death penalty that has driven the Court to apply more stringent standards of representation in capital cases. To the contrary, the cases reflect a Court that is more than willing to allow defendants to be executed even when they received less than ideal legal representation. Therefore, if death cases are different for standard of representation purposes-and the Court clearly thinks they are-the difference must lie somewhere other than in the nature of the sanction involved.

\section{ii. Avoiding Wrongful Executions}

Another possible reason that the recent ineffectiveness cases are limited to capital cases is that those cases are intended to ensure that innocent people will not be executed. Although this issue has been of great concern in recent public debates over the death penalty, ${ }^{322}$ it has gotten surprisingly little traction at the Supreme Court. It could hardly be otherwise given Herrera $v$. Collins. ${ }^{323}$ In that case, the Court rejected the view that the Constitution forbids execution of factually innocent defendants who were convicted after a fair trial. ${ }^{324}$ If the Court was troubled by the possibility of

if you want to give me the death penalty, just bring it right on. I'm ready for it."' Id. at 1937-38.

${ }^{320}$ Id. at 1937.

${ }^{321}$ Id. at 1942.

${ }^{322}$ See Carol S. Steiker \& Jordan M. Steiker, The Seduction of Innocence: The Attraction and Limitations of the Focus on Innocence in Capital Punishment Law and Advocacy, 95 J. Crim. L. \& Criminology 587, 594-95 (2005) (noting that innocencerelated concerns loom large in current controversies surrounding capital punishment).

${ }^{323} 506$ U.S. 390 (1993).

${ }^{324}$ Id. at 404, 416-17. In Herrera, Chief Justice Rehnquist went to great lengths to demonstrate that factual innocence is not itself a ground for granting federal habeas relief, but only grounds for allowing defendants to raise legal claims that were procedurally defaulted or subject to other procedural bars. See id. at 404-05. True, after making this demonstration, the majority was willing to assume that a "truly persuasive demonstration of "actual innocence" might call for relief in a capital case. Id. at 417. That assumption, however, was far less generous than it would appear at first blush. 
wrongful executions, the best way to remedy that problem would have been to make actual innocence a sufficient ground for federal habeas relief - the very approach rejected in Herrera. ${ }^{325}$ To say the least, ratcheting up the standard of representation in capital cases, in hopes that better representation would lead to acquittal of the actually innocent, would be an awfully indirect way of trying to prevent wrongful executions.

Moreover, Williams $v$. Taylor and its progeny belie concern over actual innocence. In none of these cases was there any question about whether the defendants actually committed the murders for which they were sentenced to death. The sole concern, in each case, was whether the defendant deserved to be put to death for the killings. The Court's fear was not that an innocent person had been given a death sentence, but rather that the life/death decision had been skewed in favor of death by serious defense attorney er-

Even in clear cases of actual innocence, relief would only be available "if there were no state avenue open to process such a claim." Id. Importantly, the clemency process is itself a sufficient remedy for claims of actual innocence to defeat the limited right to habeas relief assumed to exist in Herrera. See id. at 411-12. This is significant because every death-penalty jurisdiction has a clemency process of some kind. See Gershowitz, supra note 151 , at $680 \&$ n.64.

${ }^{325}$ Herrera, incidentally, was not an outlier in this regard. In Dretke v. Haley, 541 U.S. 386 (2004), the defendant was, by all accounts, not guilty under the state habitual-offender statute, yet he had been sentenced as a habitual offender to sixteen years in prison, eight times the maximum sentence he could have received for the triggering larceny conviction. The defendant argued that he was actually innocent of the habitual-offender crime and thus should be allowed to challenge his sentence despite having procedurally defaulted on that challenge. See id. at 393. This, of course, was exactly the use of "innocence" that the Court had spoken approvingly of in Herreranamely, to resurrect a defaulted legal claim, and not as a stand-alone basis for habeas relief. In the view of the Haley dissenters, the "actual innocence" exception clearly applied because the defendant was "sentenced for a crime he did not commit," an error that, "[i]n a society devoted to the rule of law," cannot be "shrugged aside as a minor detail." Id. at 399-400 (Kennedy, J., dissenting); see also id. at 396-97 (Stevens, J., dissenting) (arguing that the defendant was entitled to "immediate and unconditional release" having already served more time in jail than allowed under state law for larceny). The majority in Haley, however, was not convinced. In its view, the mere fact that the defendant was innocent of the habitual-offender crime did not necessarily bring him within the "actual innocence" exception, which it described as "narrow." Id. at 393 (majority opinion). The majority avoided the need to determine the boundaries of the "actual innocence" exception by announcing a new rule that the exception may not be invoked if there are available alternative grounds for "comparable" relief. Id. at 393-94. Thus, as in Herrera, the Haley Court made it considerably more difficult for innocent defendants to obtain habeas relief. 
rors that kept the jury from hearing strong grounds for leniency. The fact that, in Williams and its progeny, the Court upheld Strickland claims brought by death-row inmates whose guilt was clear and that, in Herrera v. Collins, the Court refused to recognize actual innocence as a constitutional barrier to execution strongly suggests that innocence concerns are not the driving force behind the recent ineffectiveness cases.

\section{iii. The Politics of Death}

The best explanation for the new approach is that it represents a direct response by the Supreme Court to the politics of death. Although politics pervades all criminal law, ${ }^{326}$ the politics of capital crimes differ in kind, not just degree, from the politics of lesser crimes. The key here is that the resource and representational quality gaps between prosecutors and the attorneys who represent indigent defendants, which exist in all criminal cases, are at their greatest - and have the greatest harmful impact-in capital cases.

Resource constraints and quality of lawyering matter most in litigated cases, and especially in litigated cases that are factually or legally complex. Very few noncapital cases are litigated; instead, more than ninety percent end in guilty pleas. ${ }^{327}$ If the prosecutor wants death, however, the case will have to be litigated. Few defendants would plead guilty to capital murder, and even if they did, a trial would still be necessary to determine the penalty. ${ }^{328}$ Moreover, few noncapital trials can match capital trials in the complexity of the issues involved. The greater legal complexity of even a runof-the-mill capital trial, as compared to most noncapital trials, is shown by the fact that the rate of reversal in appeals involving death cases is more than four times greater than the reversal rate in noncapital cases. ${ }^{329}$ The limitless scope of a capital sentencing trial, with the whole range of potential arguments for leniency available

\footnotetext{
${ }^{326}$ See generally Stuntz, supra note 62 , at $509-12$.

${ }^{327}$ See supra note 97 and accompanying text.

${ }^{328}$ For example, in Godinez v. Moran, 509 U.S. 389, 392-93 (1993), there was a trial on sentencing even though the defendant had pled guilty and refused to put on a mitigation case.

${ }^{329}$ See supra note 64.
} 
for investigation and presentation at trial, ${ }^{330}$ ensures that capital cases will be factually complex as well. This is not only the kind of litigation that plays to the weaknesses of resource-constrained capital defenders, but it is the kind of high-profile litigation in which prosecutors will marshal their greater resources and go to great lengths to win undeniable proof of their "toughness": a death sentence.

The promise of the Williams $v$. Taylor approach lies in the fact that it represents a substantial step toward counteracting death's politics. The problem that the Court has identified in Williams and other recent ineffective assistance cases is that inadequate representation by indigent defense lawyers systematically operates to deny capital juries the information they need in order to determine whether or not defendants convicted of capital crimes truly deserve death. By virtue of their significant resource advantages over public defenders and appointed counsel and strong incentives to avoid embarrassing defeats in capital cases, prosecutors will diligently investigate and vigorously present the case for death. Resourceconstrained public defenders and court-appointed counsel will be in no position to match (or, in many cases, even come close to matching) the effort and resources that prosecutors will invest in capital cases. With inadequate resources at their disposal, defense attorneys will necessarily have to decide where to allocate their scarce resources. Time and again, they have elected to focus on the guilt phase at the expense of the penalty phase, and, at the penalty stage, to cut short their efforts where they matter most-namely, in investigating their cases thoroughly in search of grounds to counter the prosecutor's case and construct a credible case for leniency.

The new ineffectiveness cases counter the perverse incentives that defense attorneys have in a regime of severe resource constraints. The Supreme Court has made it clear that, even under the stringent standards imposed by the AEDPA and even in cases involving grisly killings, it stands ready to order habeas relief in cases where death sentences likely resulted from attorney errors. It has

\footnotetext{
${ }^{3.30}$ See, e.g., Lockett v. Ohio, 438 U.S. 586, 604-05 (1978) (ruling that any type of evidence can be used, if relevant, to support a claim that a defendant should not be condemned to death). Some states apply a parallel rule allowing prosecutors to use any relevant evidence to show that execution is warranted. See, e.g., Gregg v. Georgia, 428 U.S. 153, 206 (1976) (noting this feature of the Georgia scheme).
} 
also left no doubt that inadequate resources are no excuse for those who represent the indigent in capital cases to fail to conduct reasonable investigations into their clients' backgrounds and other areas that might yield helpful evidence at the penalty phase.

In the short term, the new approach gives the federal courts a potent new weapon to rationalize the imposition of the ultimate sanction. Ordering new sentencing hearings whenever serious attorney error is reasonably likely to have tipped the scales in favor of death will help ensure that moral blameworthiness and future dangerousness - not errors or inattention by defense attorneyswill be the decisive factor in determining who gets sentenced to death. In the longer term, the new approach will create incentives for legislatures to allocate more resources to the defense of indigents charged with capital crimes. If, as is widely believed, inadequate funding and resources systematically operate to produce inadequate representation in capital cases, then legislatures can bolster the finality of future death sentences by increasing the resources that are available to indigent capital defenders at the trial stage. With greater resources at their disposal, defense attorneys will be better able to look for and present reasons for jurors to spare the defendants' lives in spite of the horrendous crimes involved. In that event, capital juries will be in a considerably better position to assess whether or not the defendant deserves death, and, in cases where juries still opt for death, those death sentences will be less vulnerable to attack on ineffectiveness grounds.

Seen in this light, the Supreme Court's recent insistence on more effective defense representation in capital cases poses no threat to the death penalty. More resources for capital defense will not enable defense attorneys to create grounds for leniency that do not exist or win life sentences based on weak mitigation evidence. In those cases, death-qualified juries will continue to impose death sentences and, as previously noted, those death sentences will be more defensible, both morally and legally, because they will be the product of a fair adversarial hearing. Even in cases where more effective representation does result in juries hearing plausible arguments for leniency where previously they would have heard little more than unadorned pleas for mercy, all more effective representation does is provide jurors with better information concerning whether or not a death sentence should be imposed. Again, where 
the aggravating circumstances outweigh the mitigating circumstances, death-qualified juries can be counted on to return death sentences. The only cases in which the new approach will potentially have outcome-altering significance is in cases where the mitigation evidence is strong enough to sway even death-qualified juries in their assessment of whether defendants deserve death-and if the Furman regime is to mean anything at all, that is exactly the kind of evidence that juries must be allowed to hear and weigh at the penalty phase.

As an example of the promise of the new approach, consider Williams $v$. Taylor, the case in which the Supreme Court embarked upon its new approach back in $2000 .{ }^{331}$ In that case, the defense attorney did not even begin to prepare for the penalty phase until a week beforehand. ${ }^{332}$ Not surprisingly, the defense failed to discover a treasure trove of mitigating evidence, including records showing that the defendant was borderline mentally retarded and had endured what the majority described as a "nightmarish childhood" of severe physical abuse and neglect. ${ }^{333}$ The attorneys also failed to offer testimony volunteered by state correctional officers that the defendant would not be a danger in prison, and failed even to return the call of a prominent prison-ministry volunteer who had offered to testify for the defendant. ${ }^{334}$ Having thus failed to discover any grounds for leniency, all the attorney could do was plead for mercy because the defendant would never have been suspected in the killings had he not come forward and confessed. ${ }^{335}$ Even then, the attorney repeatedly told the jury that it was "dumb" for his client to have confessed and that jurors would understandably find it very difficult to spare his client's life. ${ }^{336}$ The jury, not surprisingly, sentenced the defendant to death. ${ }^{337}$

By a vote of six to three, the Supreme Court overturned the sentence. Justice John Paul Stevens wrote for the majority that "trial counsel did not fulfill their obligation to conduct a thorough inves-

\footnotetext{
${ }^{331} 529$ U.S. 362 (2000).

${ }^{332}$ Id. at 395.

${ }^{333}$ Id. at 372 n. $4,395$.

${ }^{334}$ Id. at 372 n. $4,396$.

${ }^{335}$ Id. at 369.

${ }^{336} \mathrm{Id}$.

${ }^{337}$ Id. at 370.
} 
tigation of the defendant's background. ${ }^{, 338}$ Had counsel done so, they would have discovered mitigating evidence that "might well have influenced the jury's appraisal of [the defendant's] moral culpability.",339

Interestingly enough, the prosecution itself evidently agreed with the Court's assessment. On remand, the prosecutor, faced with previously unknown mitigation evidence that would have come into evidence at a new sentencing hearing, agreed to accept a life sentence. ${ }^{340}$ The prosecutor dropped his prior execution demand even though the case occurred in Danville, which is unusually aggressive (even by Virginia standards) in its use of the death penalty. ${ }^{341}$ Even there, where juries are uncommonly willing to hand down death sentences, effective defense representation-the fruits of which the defendant would have been denied but for the Supreme Court's dramatic intervention-made all the difference.

The reaction of the prosecutor on remand in Williams shows just how powerful a truly adversarial determination of the proper sentence in a capital case can be in counteracting the politics of death. When inadequate investigation of potential grounds of mitigation is as widespread as it is today, prosecutors have little incentive, at the charging stage, to try and unearth possible mitigating circumstances. In many cases, there may not be strong grounds for mitigation, and, as in Williams, even when there are, resourceconstrained defense attorneys will often fail to raise them. To the extent prosecutorial decisions to seek the death penalty are made in ignorance of possible mitigating circumstances, prosecutors will often misallocate resources to the pursuit of death sentences against individuals who have compelling grounds for leniency. As a result, individuals who deserve (and otherwise would have received) leniency may nonetheless be sentenced to death due to the

\footnotetext{
${ }^{338}$ Id. at 396.

${ }^{339}$ Id. at 398.

${ }^{340}$ See Frank Green, Death Row Veteran's Life Spared, Richmond Times-Dispatch, Nov. 15, 2000, at A1 (reporting the terms of the plea agreement reached with Williams on remand from Williams $v$. Taylor).

${ }^{341}$ See Frank Green, Killer's Turn to Religion Stirs Cry to Save Him, Richmond Times-Dispatch, Mar. 24, 1998, at B4 (noting that Danville's death-sentencing rate "is the highest per capita rate of any Virginia city"). The article further noted that as of 1998 Danville was "the only jurisdiction [in Virginia] that has sent more than three men to death row that has sent only African-Americans." Id.
} 
incompetence of their attorneys at sentencing-precisely what happened in Williams.

Raising the standard of representation in capital cases, as Williams and its progeny do, has the potential to bring added reliability to the prosecutor's determination of whether or not to seek the death penalty. After these cases, prosecutors ignore potential grounds for mitigation at their peril: if defense attorneys miss such grounds, the federal courts stand ready to vacate the resulting death sentences when the evidence eventually comes to light. To avoid wasting scarce resources and suffering embarrassing litigation defeats, conscientious prosecutors now have stronger incentives to expend some of their comparatively greater resources looking for possible grounds for mitigation that might make a life sentence a likely outcome in court. As the events on remand from Williams show, more complete information about potential mitigation evidence might well lead prosecutors to choose life in cases in which they would otherwise have sought, and quite possibly obtained, death. Even if the prosecutor's decision is unchanged by the mitigating evidence he discovers at the charging stage, that evidence, if significant enough in its likely impact, might well constitute "Brady material" that must be disclosed to the defense, making it less likely that the defense attorney will go into sentencing hearings unaware of key mitigation evidence. ${ }^{342}$ Whether or not the number of executions is reduced as a consequence, the fact remains that fuller, more accurate information for prosecutors-and, ultimately, jurors-about possible grounds for leniency will lead to fairer and more reliable determinations of whether death is warranted.

\section{CONCLUSION}

Throughout the last three decades of regulating capital punishment, the Supreme Court has progressively become savvier about the politics of the death penalty. At the beginning of this enter-

${ }^{342}$ Due process requires prosecutors to disclose to the defense any favorable evidence in the possession or control of the government that is reasonably likely to affect the outcome at trial. See Kyles v. Whitley, 514 U.S. 419, 434-35 (1995). The constitutional disclosure obligation, stemming from Brady v. Maryland, 373 U.S. 83 (1963), applies to evidence that might be used in mitigation at capital sentencing hearings. See Strickler v. Greene, 527 U.S. 263, 290-91 (1999). 
prise, the Court seemed to think that it could just point the way to what it regarded as a better future-a future in which the death penalty was relegated to the ash heap of American history-and the country would dutifully fall in line. Accordingly, the Court gave the nation a stern lecture in Furman v. Georgia about the many problems inherent in the death penalty. ${ }^{343}$ The decision sent shockwaves through the country, but it is the Court that has been reeling ever since. By constitutionalizing capital punishment, the Court inadvertently politicized it, and the political process quickly responded with new death penalty schemes crafted to correct the defects identified in Furman. Within a few short years, the nation's death chambers were back in business, with the Court's blessing, and busier than they had been in decades.

The Court's fall-back approach after the anti-Furman backlash was more modest in its ambitions. Instead of pushing toward the abolition of capital punishment, the Court worked to reform the death penalty from within the system. Within broad bounds, political actors were left free to define capital crimes as they saw fit and to choose whether certain categories of offenses or offenders should be exempt from the death penalty. If a strong consensus developed among legislatures in "death" states in favor of such exemptions, the Court would use the Eighth Amendment's proportionality principle to impose that consensus on outlier states, but otherwise would avoid matters of substance concerning death eligibility. In place of substantive regulation of the death penalty, the Court closely regulated the procedures through which the ultimate sanction is administered. The goal was to replace the standardless discretion to impose death that characterized the pre-Furman era with a structured, law-like process that would accurately and fairly sort the few offenders who truly deserve death from the larger universe of offenders who are death-eligible but nevertheless do not deserve to die.

At least in terms of longevity, this approach was more successful, but it, too, ultimately failed. Simply put, a dominantly procedural approach to death penalty reform was too easy for the political branches to subvert. New procedural mandates from the courts were met, in the short term, by statutory amendments fixing the

${ }^{343} 408$ U.S. 238 (1972). 
procedural defects identified by the courts. In the case of errors that simply required resentencing, prosecutors often succeeded in obtaining new death sentences. In the longer term, legislatures expanded the number of capital crimes, made it easier to prove death-eligibility, and grossly underfunded capital defense. State governors, who once liberally granted clemency to deserving individuals on death row on grounds of fairness and mercy, resolved to let the judicial process have the final word, in all but truly exceptional cases, concerning who lives and who dies. As the politics of death worked to undermine the Court's regulatory efforts, the death penalty soared to new heights.

The Court's next, and latest, move was to supplement the dominantly procedural approach with what might be called "political" reforms; that is, judicial reforms that the politics of death could not readily undermine. Two such reforms have been at the center of the Court's attention in recent years. The first is more aggressive use of the Eighth Amendment's proportionality principle to impose real substantive limits on the death penalty. The second is the invigorated right to the effective assistance of counsel applicable to capital cases. Though these tools are far from new, the Court has refined them over the last few years in ways that take direct aim at the politics of death.

Take the new approach to proportionality first. The Court seems convinced that, although the public favors categorical exemptions for certain kinds of offenders, such as juveniles or the mentally retarded, the politics of death will virtually ensure that measures to create those exemptions will not be enacted, except in the clearest of cases. Lowering the threshold for finding the legislative "consensus" necessary to carve categories of offenses and offenders out of the scope of the death penalty allows the Court to break this logjam in the political process. At the same time, by considering polling data concerning how the public views the exemptions the Court is asked to recognize under the Eighth Amendment, the Court avoids letting the search for societal consensus be derailed by death penalty statutes or decisions made by unrepresentative, death-qualified juries that allow broader application of the ultimate sanction than the public actually supports-and minimizes the danger of the kind of debilitating backlash that Furman sparked. 
The most promising prospect for real reform lies with the new standards for measuring attorney effectiveness in capital cases. Holding capital defenders to the same standards of representation that apply to other members of the bar is a direct assault on the pervasive legislative strategy of underfunding indigent defense. If the Supreme Court continues to reverse in cases where attorney errors undermine the reliability of the capital sentencing process, prosecutors-and hence legislatures-may soon see that underfunding indigent capital defense is no longer the cost-free strategy it has been for far too long. Underfunding the defense of indigents charged with capital crimes will, for the first time, have a high cost in that it will make it more difficult for prosecutors to get death sentences that will stand up in court (and, more to the point, on federal habeas review). This will give the political processes incentives to ease the burdensome conditions that have made ineffective representation such a pervasive reality in capital cases-heavy workloads, understaffing, inadequate resources, and so forth-and state judges incentives to do more to police the effectiveness of defense counsel in capital cases. Better defense representation might or might not result in fewer death sentences, but, in either case, the death sentences that are handed down will be more likely to stand up on appeal and more defensible, as a moral matter, than cases where drunk or sleeping defense attorneys ${ }^{344}$ or other serious attorney errors played a major role in the imposition of a sentence of death.

The revitalized capital proportionality principle and ineffectiveness standards are powerful new tools in the ongoing effort by the Supreme Court to bring rationality and fairness to the death penalty. The results they have produced so far have been dramatic. In the long term, though, will these "political" reforms really make a difference? Only time will tell. It seems fairly certain, however, that the new approach to constitutional regulation of capital punishment has far more promise in terms of achieving the goals of Furman than the Furman regime itself. That prospect is one that all fair-minded people, regardless of where they stand on the death penalty, should welcome.

\footnotetext{
${ }^{344}$ See supra note 247 and accompanying text.
} 
